\title{
USE OF SHREDDED TIRE CHIPS AND TIRE CRUMBS AS PACKING MEDIA IN TRICKLING FILTER SYSTEM FOR LANDFILL LEACHATE TREATMENT
}

\author{
By
}

Bibekananda Mondal, M. Eng. (Civil) India 1992

\author{
A thesis \\ presented to Ryerson University
}

\author{
In partial fulfillment of the \\ requirements for the degree of \\ Master of Applied Science in the Program of \\ Environmental Applied Science and Management
}

Ryerson University, Toronto, Ontario, Canada 2006

@ Bibekananda Mondal 2006 


$\begin{array}{ll}\begin{array}{l}\text { Library and } \\ \text { Archives Canada }\end{array} & \begin{array}{l}\text { Bibliothèque et } \\ \text { Archives Canada }\end{array} \\ \begin{array}{l}\text { Published Heritage } \\ \text { Branch }\end{array} & \begin{array}{l}\text { Direction du } \\ \text { Patrimoine de l'édition }\end{array} \\ \begin{array}{l}\text { 395 Wellington Street } \\ \text { Ottawa ON K1A ON4 }\end{array} & \begin{array}{l}\text { 395, rue Wellington } \\ \text { Ottawa ON K1A ON4 } \\ \text { Canada }\end{array}\end{array}$

Your file Votre référence ISBN: 978-0-494-29196-2 Our file Notre référence ISBN: 978-0-494-29196-2

NOTICE:

The author has granted a nonexclusive license allowing Library and Archives Canada to reproduce, publish, archive, preserve, conserve, communicate to the public by telecommunication or on the Internet, loan, distribute and sell theses worldwide, for commercial or noncommercial purposes, in microform, paper, electronic and/or any other formats.

The author retains copyright ownership and moral rights in this thesis. Neither the thesis nor substantial extracts from it may be printed or otherwise reproduced without the author's permission.
AVIS:

L'auteur a accordé une licence non exclusive permettant à la Bibliothèque et Archives Canada de reproduire, publier, archiver, sauvegarder, conserver, transmettre au public par télécommunication ou par l'Internet, prêter, distribuer et vendre des thèses partout dans le monde, à des fins commerciales ou autres, sur support microforme, papier, électronique et/ou autres formats.

L'auteur conserve la propriété du droit d'auteur et des droits moraux qui protège cette thèse. $\mathrm{Ni}$ la thèse ni des extraits substantiels de celle-ci ne doivent être imprimés ou autrement reproduits sans son autorisation.
In compliance with the Canadian

Privacy Act some supporting forms may have been removed from this thesis.

While these forms may be included in the document page count, their removal does not represent any loss of content from the thesis.
Conformément à la loi canadienne sur la protection de la vie privée, quelques formulaires secondaires ont été enlevés de cette thèse.

Bien que ces formulaires aient inclus dans la pagination, il n'y aura aucun contenu manquant.

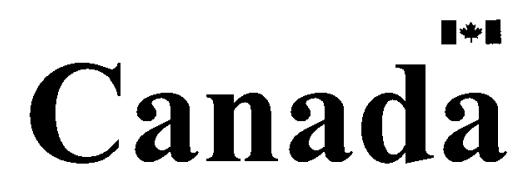




\section{Author's Declaration:}

I hereby declare that I am the sole author of this thesis.

I authorize Ryerson University to lend this thesis to other institutions or individuals for the purpose of scholarly research.

I further authorize Ryerson University to reproduce this thesis by photocopying or by other means, in total or in part, at the request of other institutions or individuals for the purpose of scholarly research. 


\begin{abstract}
Use of shredded tire chips and tire crumbs as packing media in trickling filter system for landfill leachate treatment
\end{abstract}

\begin{abstract}
Bibekananda Mondal
MASc, 2006

Environmental Applied Science and Management Program, Ryerson University, Toronto, Ontario
\end{abstract}

\begin{abstract}
Scrap tire stockpiles are havens for pests and mosquitoes; thereby this poses a potential health risk. This research work was carried out in six stages to determine the use of scrap tire materials in trickling filter system to treat landfill leachate; 81 to $96 \% \mathrm{BOD}_{5}, 76$ to $90 \% \mathrm{COD}$ and 15 to $68 \% \mathrm{NH}_{3}-\mathrm{N}$ from leachate were removed. Organic removal appears to be largely related with total dissolved solids reduction from leachate. Sudden increase in organic content of effluent from time to time could be attributed to biomass sloughing and clogging in trickling filters. However, tire crumbs exhibited more consistent organic removal through out the experiment. Because of high surface area of tire materials, a thick layer of biomass was attached on them and sloughed off at an interval of 21 days. Further research and practical applications are needed to establish usefulness of tire materials in this field.
\end{abstract}




\section{Acknowledgement}

This thesis work on "Use of shredded tire chips and tire crumbs as packing media in trickling filter system for landfill leachate treatment" has been carried out under supervision of Dr. Mostafa Warith, Associate Professor, Civil Engineering Department, Ryerson University, Toronto, Ontario. The author expresses his deep gratitude to Prof. Dr. Warith and Prof. Dr. Ronald Pushchak, Program Director, Environmental Applied Science and Management Program, Ryerson University for their support, valuable guidance, constructive suggestions and constant inspiration, without which preparation of this thesis would have been impossible.

The author thanks Prof. Dr. Grace Luk of Civil Engineering Department, Ryerson University for her support and also thanks all other staffs \& faculty members of Civil Engineering Department for their continued support to complete this research work. The author thanks all examination committee members including Prof. Dr. Mehrab Mehrvar, Prof. Dr. Vadim Boston for suggesting valuable corrections in this thesis. The author also thanks Mr. Stephen Burns, President of B. M. Ross and Associates Limited for reviewing this thesis.

The author also expresses his gratitude to Mr. Ali Hemati, Senior Technician, Mr. Peter Scharping, Senior Technician of Chemical Engineering Department and Mr. Dennis Wemsley of Ryerson University Analytical Center, Ryerson University in Toronto for their valuable supports. Author expresses his sincere thanks to $\mathrm{Mr}$. Ryan Politewicz, Mr. Joseph of Trensept Automation Inc., St. Catherines, Ontario and Mr. Yugine Brenda of Keele Valley Landfill, City of Toronto, Ontario for their valuable continued cooperation to complete this research work.

Bibekananda Mondal

Ryerson University, Toronto

September 26, 2006 


\section{Table of Contents}

Chapter 1: Introduction 1

1.1 Introduction 1

1.2 Thesis objective 4

1.2.1 Scope of Work 5

Chapter 2: Literature review $\quad 6$

$2.1 \quad$ Literature review 6

2.1.1 Characteristics of shredded tire materials 6

2.1.2 Effect of Environmental factors on tires 9

2.1.3 Landfill leachate generation 10

2.1.4 Characteristics of landfill leachate 11

2.1.5 Shredded tires - Applicability for attached growth 12

2.1.6 Treatability of landfill leachate 14

2.1.7 Attached growth and trickling filter system 15

2.1.8 Packing media for trickling filter system 15

2.1.9 Applicability of scrap tire as packing media 16

2.1.10 Trickling filter - treatment process 17

2.1.11 Leachate treatment by trickling filter 18

Chapter 3: Materials and Methods 22

$3.1 \quad$ Materials 22

3.1.1 Packing material 22

3.1.2 Synthetic leachate 23

3.1.3 Trickling filter pilot-plant 25

3.2 Experimental methods 27

3.2.1 Preparation of influent 27

$\begin{array}{lll}3.2 .2 & \text { Trickling filter set up and operation } & 27\end{array}$ 
Chapter 4: Results and Discussion

4.1 Results \& Discussion 31

4.1.1 Facts and figures $\quad 35$

4.1.2 Performance of trickling filter pilot-plant 41

4.1.3 Biomass growth \& sloughing 61

4.1.4 Mass balance analysis $\quad 62$

Chapter 5: Conclusions $\quad 65$

5.1 Conclusions 65

Chapter 6: Recommendations 68

6.1 Recommendations 68

Chapter 7: References $\quad 69$

Appendix-1: Sample Calculation $\quad 75$

Appendix-2: Components of the trickling filter pilot-plant, methods $\quad 76$ and instruments used in laboratory analysis

Appendix-3: $\mathrm{pH}$ and temperature of trickling filter units, variation in 78 $\mathrm{BOD}_{5}, \mathrm{COD}, \mathrm{NH}_{3}-\mathrm{N}$, TSS and TS

Appendix-4: Supplementary photographs 82 


\section{List of Tables}

Table 1: Composition of synthetic leachate ............................................. 24

Table 2: Composition of Trace Metal Solution ....................................... 25

Table 3: Details of stages adapted for trickling filter pilot plant study ......... 32

Table 4: Stage-wise removal efficiencies for $\mathrm{BOD}_{5}, \mathrm{COD}$ and $\mathrm{NH}_{3}-\mathrm{N} \quad \ldots . .36$

Table 5: Stage-wise removal efficiencies for TSS and TS ….................... 37

Table 6: Case studies on mass balance analysis....................................... 63

Table 7: Components of the pilot-plant trickling filter system (App.-2) ....... 76

Table 8: Methods and Instruments used in laboratory analysis (App.-2)...77

Table 9: $\mathrm{pH}$ and temperate of trickling filter units (App. - 3) .................78

Table 10: Stage-wise TSS and TS analysis (App.-3) ................................ 80

Table 11: Stage-wise $\mathrm{BOD}_{5}, \mathrm{COD}$ and $\mathrm{NH}_{3}-\mathrm{N}$ analysis (App.-3) .............. 81 


\section{List of Figures}

Figure 1: Schematic diagram of trickling filter pilot-plant. ....................26

Figure 2: Variation of $\mathrm{pH}$-values for tire chips packed trickling filter ...33

Figure 3: Variation of $\mathrm{pH}$-values for tire crumbs packed trickling filter...34

Figure 4: Variation in $\mathrm{BOD}_{5}$ removal efficiency in varied reaction time..38

Figure 5: Variation in COD removal efficiency in varied reaction time...39

Figure 6: Variation in $\mathrm{NH}_{3}-\mathrm{N}$ removal efficiency in varied reaction time.40

Figure 7: Variation in $\mathrm{BOD}_{5}$ removal efficiency in stage $1 \ldots \ldots \ldots \ldots \ldots . . . . . .41$

Figure 8: Variation in COD removal efficiency in stage 1 .................... 42

Figure 9: Variation in TSS removal efficiency in stage 1 ..................... 43

Figure 10: Variation in $\mathrm{BOD}_{5}$ removal efficiency in stage 2 ................... 44

Figure 11: Variation in COD removal efficiency in stage 2 .................... 45

Figure 12: Variation in TSS removal efficiency in stage 2 ..................... 46

Figure 13: Variation in $\mathrm{BOD}_{5}$ removal efficiency in stage $3 \ldots \ldots \ldots \ldots \ldots \ldots . . . .47$

Figure 14: Variation in COD removal efficiency in stage3 .................... 48

Figure 15: Variation in $\mathrm{NH}_{3}-\mathrm{N}$ removal efficiency in stage 3 .................. 49

Figure 16: Variation in TSS removal efficiency in stage 3 .....................50

Figure 17: Variation in $\mathrm{BOD}_{5}$ removal efficiency in stage $4 \ldots \ldots \ldots \ldots \ldots \ldots . . . . .51$

Figure 18: Variation in COD removal efficiency in stage 4 .....................52

Figure 19: Variation in TSS removal efficiency in stage 4 ......................53

Figure 20: Variation in $\mathrm{BOD}_{5}$ removal efficiency in stage $5 \ldots \ldots \ldots \ldots \ldots . \ldots 54$

Figure 21: Variation in COD removal efficiency in stage 5 ....................55

Figure 22: Variation in $\mathrm{NH}_{3}-\mathrm{N}$ removal efficiency in stage $5 \ldots \ldots \ldots \ldots \ldots \ldots . . . .56$

Figure 23: Variation in TSS removal efficiency in stage $5 \ldots \ldots \ldots \ldots \ldots \ldots \ldots . . . . .57$

Figure 24: Variation in $\mathrm{BOD}_{5}$ removal efficiency in stage 5 ...................58

Figure 25: Variation in COD removal efficiency in stage 5 ...................... 59

Figure 26: Variation in $\mathrm{NH}_{3}-\mathrm{N}$ removal efficiency in stage 6...................60 


\section{List of Acronyms}

$\begin{array}{ll}\text { App. } & \text { Appendix } \\ \text { BOD }_{5} & \text { 5-day Biochemical oxygen demand } \\ \text { CIWMB } & \text { California Integrated Waste Management Board } \\ \text { COD } & \text { Chemical oxygen demand } \\ \text { CNS } & \text { Central Nervous System } \\ \text { CP } & \text { Chloro Phenol } \\ \text { DCP } & \text { Di-chloro Phenol } \\ \text { FSS } & \text { Fixed suspended solids } \\ \text { GAC } & \text { Granular activated carbon } \\ \text { Gpm } & \text { Gallon per minute } \\ \text { KVL } & \text { Keele Valley Landfill } \\ \text { Lpm } & \text { Liter per minute } \\ \text { MLSS } & \text { Mixed Liquor Suspended Solids } \\ \text { NESC } & \text { National Environmental Services Centre } \\ \text { NH } \\ 3 \text {-N } & \text { Ammonia nitrogen } \\ \text { PAC } & \text { Powdered activated carbon } \\ \text { TF1 } & \text { Trickling filter unit no. 1 } \\ \text { TF2 } & \text { Trickling filter unit no. 2 } \\ \text { TSS } & \text { Total suspended solids } \\ \text { TS } & \text { Total solids } \\ \text { RT } & \text { Reaction time } \\ \text { VOC } & \text { Volatile organic carbon } \\ \text { VSS } & \text { Volatile suspended solids }\end{array}$




\section{Chapter 1: Introduction}

\subsection{Introduction}

Scrap tires are undesirable waste material. The generation of huge amounts of scrap tire is a growing concern in Canada and United States. As scrap tire stockpiles pose a potential health risk, finding options for scrap tire use is important. Recent inventions relate to transforming undesired scrap tires into usable substances by processing them for recycling, reusing scrap tires (losif et al., 1997). Rubber from scrap tires has been investigated and used successfully in the construction field. There are already a number of applications for scrap tires including playground equipment, erosion control, highway crash barriers, guard rail posts, noise barrier, asphalt pavement mixtures, as fuel in cement kilns, pulp and paper plants (Toutanji et al., 1996).

The product of tire shredding is usually referred to as "tire chips" when they are generally between 12 and $50 \mathrm{~mm}$ in size and have most of the steel beltings removed, the term tire shred or rough shred is used for larger tire particles (Lee et al., 1999). The New York State Roundtable defines tire chips as "A classified scrap tire ... which is generally two inches $(50.8 \mathrm{~mm})$ or smaller and has most of the wire removed ..." and shreds as "Pieces of scrap tires that . . . are generally between $50 \mathrm{~mm}$ (1.97") and $305 \mathrm{~mm}$ (12.02") in size" (Lee et al., 1999). Another recyclable tire product is tire crumb. This is produced mechanically. While chips are granulated to crumbs, the biggest advantage is that loose steels and fibers are completely removed by this process. So far tire crumbs have been used in the construction field, and in recycled rubber production (Tire recycling, Govt. of Canada, 2002).

The suitability of shredded rubber tires as an alternative to crushed stone in the leachate collection drainage layer of a municipal solid waste landfill site has been investigated (Warith et al., 2004). There are some practical considerations for the use of tire shreds, which include health and safety aspects of handling shredded 
tires as steel belt fragments and steel rims in the tires which results in many sharp fine steel pieces being present (Warith et al., 2004). Two types of tire chips are available, referred to as "higher quality" (HQ) tire chips and "lower quality" (LQ) tire chips. HQ chips are characterized by regular edged chips with the appearance of being cut as opposed to the torn appearance of $L Q$ tire chips (Warith et al., 2004). The principal chemical component of tire is a blend of natural and synthetic rubbers, other components include carbon black, silica, cure accelerators, sulfur, cobalt salts, polymers, paraffin waxes, antioxidants, pigments, fabrics, oils, softeners, bead and belt materials (Grimes et al., 1999; Warith et al., 2004). It could be envisaged that once tires are disposed, most of these components either become toxic or might form toxic substances which could cause serious environmental impacts. Therefore, it is imperative to recycle and reuse scrap tires in environmentally acceptable methods.

Certain important characteristics of tire chips, such as compressibility, hydraulic conductivity, surface area, sorption capacity, thermal conductivity and environmental factors like $\mathrm{pH}$ and temperature might influence wastewater treatment. Thicker biofilm and a surprising level of supported invertebrates onto the tire chips used in trenches, as compared to stone aggregates, have been noticed in North Carolina and South Carolina (Grimes et al., 1999). Several kinds of micro and macro-organisms including grazers, saprophytic feeders and filter feeders were found in South Carolina tire chip trenches; this complexity and diversity of organisms demonstrated the potential for wastewater treatment in tire chip aggregates (Grimes et al., 1999). Recently, significant attention has been given to landfill leachate treatment in municipal areas (Kargi et al., 2003). One acceptable treatment method is biological, but a commonly adapted suspended growth system, like a conventional activated sludge process can remove only a small proportion of organic carbon (Knox et al., 1993, Kargi et al., 2003). Currently, researchers are investigating the efficiency of attached growth systems including trickling filters using a suitable media for landfill leachate treatment. 
The media bed is the most essential component of a trickling filter system because this is the only support material for growth of microorganisms, thus enabling a biofilm to be established on it. Overall process performance is entirely dependent on the performance of the media bed. Biofilm formation on tire chips in drainage trenches has raised the possibility of using tire chips as filter media in a trickling filter system (Grimes et al., 1999). Scrap tire is an easily available material at solid waste disposal sites. Chips, crumbs made out of scrap tires are usable rubber materials for further use. Investigating the suitability of these shredded tire chips and tire crumbs as packing media for the growth of microorganism is of importance.

So far, based on real world applications and research, it is understood that tire chips are favorable substitute for stones in on-site drainage systems and, to date, there is no report of significant failure where using tire chips. Recent applications of tire shreds in treatment systems such as, drain-fields, septic tanks, constructed wetlands indicated potential opportunities for recycling scrap tires. Compressibility and permeability are positive factors for using tire chips as fill material in several civil engineering applications. Other factors like sorption capacity and surface area, along with permeability, must be studied further in order to understand and determine if there is any additional benefit to use tire chips as filter media in filtration units.

Using scrap tire seems to be a priority given the environmental implications of not processing scrap tires such as mosquito breeding, potential leaching of various constituents and thereby contamination of soil and groundwater. Leachate is a toxic wastewater from landfill, having a wide range of organic and inorganic matter from decomposing solid wastes. Therefore, reducing the serious health effects of leachate by proper collection and cost-economic treatment of leachate has become a necessity. Several researchers have already successfully carried out experiments on trickling filter systems for nitrification of ammonia from leachate. They have tested biodegradability and removed various kinds of 
hydrocarbons from leachate. Some of them have investigated the requirements for pre-treatment, some have investigated polishing treatment. Observations clearly indicate that a robust treatment system for landfill leachate treatment is an important requirement. If the effects of using shredded tires can be established and the process is economical using tire materials, it could be presumed that using shredded tire chips and tire crumbs as packing media in trickling filter may emerge as a suitable option for tire recycling. This can also lead to an economic and robust treatment system at the same time.

Leachate treatment, being a challenging issue, has been targeted by various treatment technologies. Aerobic biofilters including trickling filters are proven to be the most advantageous and least costly treatment systems. There are disadvantages of trickling filter systems including sludge generation, clogging and odor problems. However, considering the advantages; such as the reliability of the process, requirement of a comparatively small land area, efficiency in treating high concentrations of organic material (depending on packing media), the ability to handle shock loads, lower power requirements and low cost, it can be said that the trickling filter with a suitable packing media, might have the potential to be rated as a cost-effective and efficient secondary treatment for a high strength wastewater like landfill leachate. Therefore, further research is required to determine the suitability of tire chips and crumbs as media which will increase performance reliability and make tire based systems the best suited treatment option for biological wastewater treatment.

\subsection{Thesis Objective}

Recent studies have established that biofiltration is a proven technology for removal of hydrocarbons, VOCs and heavy metals from landfill leachate, but the overall treatability of landfill leachate, using scrap vehicle tire chips as packing media in trickling filter, has yet to be examined. The prime objective of this thesis is to determine suitability of tire chips and tire crumbs as packing media for an attached growth process treating landfill leachate. This may also serve a noble 
purpose related to recycling scrap vehicle tires. So far, these concerns are well understood and supported by researchers due to non-biodegradability of tires and toxicity posed by vehicular tires. However, In order to meet this objective, efficiency of landfill leachate treatment has been monitored and evaluated during the course of this experiment, starting from $27^{\text {th }}$ December, 2005 to $2^{\text {nd }}$ April, 2006.

\subsubsection{Scope of Work}

The scope of this research work includes mainly the following tasks,

- Setting up of a trickling filter pilot-plant consisting of two filter towers packed with tire chips and tire crumbs in the Geo-Environmental Laboratory, Civil Engineering Department, Ryerson University.

- Monitoring and evaluating the degree and variation of leachate treatment efficiency achieved throughout the experimental period to understand suitability of tire chips and tire crumbs as packing media in trickling filters.

- Monitoring biofilm growth and periodic sloughing from tire materials and conducting a mass balance analysis in order to determine the treatment efficiency exhibited by the packing media. 


\section{Chapter 2: Literature review}

\subsection{Literature review}

\subsubsection{Characteristics of shredded tire materials}

This section is intended to focus on certain important characteristics of tire chips, such as compressibility, hydraulic conductivity, specific gravity, sorption capacity, thermal conductivity and the influence of environmental factors like $\mathrm{pH}$, temperature on those characteristics, in order to understand the applicability of tire chips in the wastewater treatment sector. It is important to note that the process of manufacturing tires combines raw materials into a special form that yields unique properties such as strength, resiliency, conductivity, high absorption and adsorption of chemicals, making scrap tires suitable for use as fill material in several civil engineering applications, such as highway embankment drainage systems. Those same properties are being investigated for wastewater treatment processes.

\section{Compressibility}

Shredded tires are compressible materials, the overburden pressure and resulting compression of tire shreds is important because leachate drainage material is located at the base of the waste mass (Warith et al., 2005). Also compressibility has an effect on tire material's settlement and unit weight, as well as the settlement and deflection caused by temporary loads after construction. In general, it appears that compressibility of tire shreds decreases as the stress level increases. Small tire chips have much lower compressibility than large sized tire shreds, because the void ratio of large sized tire shreds is much more than that of smaller tire chips (Yang et al., 2002). It has been determined that there is no significant difference between higher quality and lower quality tire chips as regards to compressibility, but at lower strain level, slightly less applied stress was required to compress $H Q$ tire chips than that was required for $L Q$. The 
slightly higher angle of internal friction in the $L Q$ chips has been considered reason for this (Warith et al., 2004).

\section{Hydraulic conductivity}

Shredded tires are very permeable material. The permeability of tire shreds is much greater than most granular soils, with experimental values ranging from $0.58 \mathrm{~cm} / \mathrm{s}$ to $23.5 \mathrm{~cm} / \mathrm{s}$. As tire shreds possess sufficient hydraulic conductivity and their voids allow air circulation, aerobic conditions will prevail into the systems using them as fill material. It has been observed that the permeability of tire shreds varies according to the vertical loads applied, but even then permeability of tire shred samples consistently remains two to three orders of magnitude higher than the design performance criterion of $0.01 \mathrm{~cm} / \mathrm{s}$ for municipal landfill drainage system (Warith et al., 2005).

Tire shreds have a hydraulic conductivity of approximately $0.03 \mathrm{~cm} / \mathrm{s}$, which is a good indication that they are well suited for drainage material in landfill leachate collection systems (Gonzales et al., 1995). Tire chips in drainfields were found to be better than stone aggregates in terms of porosity (Grimes et al., 1999). It is obvious that hydraulic conductivity is important aspect of tire shreds and tire chips and justifies their capability as a suitable packing media in attached growth process. It has been suggested that the overall hydraulic conductivity of the shredded tire drainage layer may be reduced in a landfill environment due to the biological clogging and migration of fines (Warith et al., 2004).

\section{Sorption capacity}

An important physiological feature of tire chips is their sorption capacity. Adsorption capacity of tire chips was evaluated by comparison with granular activated carbon (GAC) reported by USEPA, 1980 (Shin et al., 1999). Shredded tires have been found to adsorb volatile organic compounds (VOCs) from 1 to $6 \%$ of GAC adsorption capacity on a volume basis (Shin et al., 1999). Therefore, they have been used in leachate collection systems as a medium for removing 
VOCs on several occasions. Another study revealed that shredded tires were capable of removing VOCs emitted from a wastewater treatment plant aeration basin (Park and Jhung, 1993).

Removal of chlorinated hydrocarbons through adsorption by scrap tire chips is also another good example. Maximum adsorption capacity of 2, 4-dichlorophenol (DCP) through tire chips at $\mathrm{pH} 5$ was estimated to be approximately $0.3 \%$ of GAC, whereas the maximum adsorption capacity for 4-chlorophenol (CP) was $0.04 \%$ of GAC (Shin et al., 1999). Organic compounds can be primarily sorbed onto the tire's rubber polymeric material and partially onto other materials in the tire rubber, such as carbon black (Kim et al., 1997). In their experiment they found that only a small percentage $(3.5 \%-7.9 \%)$ of the total organic compound sorbed onto tire chips was desorbed, hence another application for scrap tires is to use them as a sorptive medium (Kim et al., 1997; Edil et al., 2004). Once biological decomposition of organic compounds sorbed onto tire chips is started, more organic compounds will be sorbed onto them. Tire chips were also investigated for water absorption capacity. This is basically the amount of water absorbed onto the surface of the tire chip particles, these values ranged from 2$4.3 \%$, and a water absorption range of $1-2.5 \%$ was suggested (Lee et al., 1999). The rate of organic compound sorption is a function of the diffusion coefficient and not the surface area; hence tire chip size does not play a significant role for sorption (Kim et al., 1997). But surface area of tire chip may be the significant criteria for slime growth.

Organic compound sorption is directly related to organic removal from effluent. The percent COD removal through adsorption by powdered activated carbon (PAC) was examined and a $48.80 \%$ COD removal was achieved by PAC adsorption alone at $5 \mathrm{~g} / \mathrm{PAC}$ concentration at the end of 30 hour batch-fed operation (Kargi et al., 2003). They conducted experiments with varying PAC concentrations $(0-5 \mathrm{~g} / \mathrm{l})$ and obtained COD removal in the range of $17.40-48.80$ $\%$ by adsorption alone. Carbon black, being a component of tire, is expected to 
be equally efficient at adsorbing and removing organics from effluent streams which flow across or along the surface of tires.

\section{Thermal Conductivity}

The thermal conductivity of tire shreds is lower than typical soils, and varies depending on the size of the shreds. As particle size increases, and more air can circulate in the voids, thermal conductivity increases, and the tire shreds become less effective as insulators (Univ. of Maine, 2004). Thermal conductivity was calculated for tire shreds with a maximum size of 2 inches and a value of 0.12 Btu/hr-ft- ${ }^{\circ} \mathrm{F}\left(0.20 \mathrm{~W} / \mathrm{m}^{\circ}{ }^{\circ} \mathrm{C}\right)$ was obtained (Humphrey et al., 1999). It is also to be noted that thermal conductivity also tends to increase as density of tire increases.

\section{Surface area}

Materials to be used as media must have enough surface area to support biomass attachment and shall not inhibit the growth of the biomass. Surface area of scrap tire was calculated by assuming tire shape as sphere after measuring its volume. The surface area of tire is found to be 6.4 times that of granite and 3.5 times that of briquette ashes (Shin et al., 1999). Out of these data, it can be inferred that scrap tire could be used as media for biofilm reactors.

\section{Specific gravity}

Based on several studies, the specific gravity of tire shreds ranges from 1.02 to 1.27 (Shin et al., 1999). These values are less than half the specific gravities for conventional soils. This clearly indicates that tire chip is a comparatively light weight substance and therefore, easier to handle.

\subsubsection{Effect of environmental factors on tires}

The effect of $\mathrm{pH}$ in the range of 4 to 9 on the shredded tire compressibility was noted to be minimal. After a two week period, the shredded tire samples were slightly softer than at the initial condition. Tests carried out at low, high and neutral $\mathrm{pH}$ conditions and for various exposure periods indicated that $\mathrm{pH}$ and 
exposure duration did not significantly influence the compressibility and hydraulic conductivity characteristics of the shredded tire samples (Warith et al., 2004). It is noted that because of good thermal conductivity, rubber samples are generally found to be isothermal (Bouvir et al., 1987). This means they have an equal or constant temperature with respect to either space or time. There is no such significant effect on tire shreds because of shift in temperature, but when tire chips are subjected to exceptionally high temperature, in the range of 300 to $500^{\circ} \mathrm{C}$ or even higher, those are expected to be pyrolyzed.

\subsubsection{Landfill leachate generation}

When water percolates through landfill, it picks up organic and inorganic materials from decomposing solid waste in the landfill and finally becomes leachate (Lo et al., 1996). Basic factors affecting leachate are as below,

- The type of waste material in the landfill

- Landfill conditions including pH, temperature, moisture, age and climate

- Characteristics of precipitation entering into the landfill

The amount of leachate produced is directly linked to the amount of precipitation around the landfill (Dunbar landfill, 2003). The amount of liquid waste in the landfill also affects the quantity of leachate produced. A large landfill site will produce a greater amount of leachate than a smaller site. Leachate from landfills normally contains toxic chemicals like toluene, xylene, phenols, benzene, nickel, cadmium compounds, lead and mercury. These can cause serious health effects like euphoria, excitement, CNS depression, nausea, vomiting, diarrhea, dermatitis, chest pain, pneumonitis, and pulmonary oedema etc. Chronic exposure to those chemicals may be fatal, irreparable damages like renal failure, kidney damage, prostate and lung cancer, chronic hypertension are possible according to recent studies (Dunbar landfill, 2003). Hence, it is important to study the characteristics of landfill leachate in detail and determine the treatability of leachate. This review intends to cover current state of knowledge in terms of leachate characteristics and its treatability. 


\subsubsection{Characteristics of landfill leachate}

The composition of solid wastes and site conditions are different from site to site, hence composition of leachate varies (Lo, 1996). Leachate is a dark brown coloured liquid and has a strong odor (Chen et al., 1996). The strength of leachate generated from a sanitary landfill can be evaluated in terms of gross organic parameters such as COD, BOD 5 and TOC (Lo, 1996). The ratio of COD to TOC reflects the characteristics of the organic content of leachate. The maximum possible ratio of COD to TOC is about 4.0 for young fills and can be as low as 1.16 for old fills (Lo, 1996; Yang, 2002). Another important ratio is $\mathrm{BOD}_{5} / \mathrm{COD}, \mathrm{BOD}$ is a direct measure of the biodegradability of leachate. It has been identified that the ratio of $\mathrm{BOD}_{5}$ to $\mathrm{COD}$ decreases as the age of the landfill increases (Lo, 1996). Therefore, the trend is similar to that of COD/TOC. Hence, it is clear that the amount of biologically inert material in leachate increases with the increasing age of landfill.

Secondly, leachate generated by infiltrating rainwater from landfills contains high concentrations of inorganic contaminants (Lo, 1996). However, as the age of a landfill increases, concentrations of inorganic material in leachate decrease (Lo, 1996). For example, the amount of sulphate in leachate reduces because of the reduction of sulphate to sulfide as a result of anaerobic conditions prevailing in a landfill (Lo, 1996). Analyses for heavy metal content in leachate samples of landfills in Hong Kong showed that heavy metals such as chromium, copper, iron, zinc were generally present in high concentrations (Lo, 1996). However, concentrations of these heavy metals decreased rapidly with the age of landfill. A high degree of metal solubilization was noticed in the case of a young landfill because of the formation of organic acids which basically resulted into lower $\mathrm{pH}$. As the landfill age increased, higher $\mathrm{pH}$ values decreased the amount of metal solubilization (Lo, 1996). 


\section{Effect of rainfall and impact of landfill age}

Treatment of leachate becomes crucial while mixed with rain. This also decreases concentration of organic content. Obviously the flow of leachate increases but $\mathrm{BOD}_{5}, \mathrm{COD}$ and $\mathrm{TOC}$ decrease. During the initial rainy days, concentration of these parameters was observed to be higher in several cases due to the effect of initial wash-out (Chen, 1996). The ratio of VSS/FSS also decreases over time, although this decrease is due to the decrease in the rate of degradation. Recent studies have revealed that this phenomenon is also accelerated by rainwater washing (Chen, 1996). It has been identified that concentrations of organic and inorganic constituents of leachate diluted but also exhibited different patterns of dilution from each other in a continuous and continual mode of raining. During continuous rain, concentrations of organics initially increased and then decreased linearly, but in continual mode of rain there was no significant increase initially but decreased in a non-linear fashion but steadily (Chen, 1996).

In general, BOD concentrations in landfill leachate are initially higher than at later stages, because the concentration gradually reduces with increasing landfill age. In Taipei, Taiwan $\mathrm{BOD}_{5} / \mathrm{COD}$ ratios of initial leachate were 0.6 to 0.8 in the Futekeng sanitary landfill site, but lowered to 0.2 to 0.4 after 5 years of operation (Chen, 1996), the $\mathrm{BOD}_{5} / \mathrm{COD}$ ratio first decreased sharply within one year and then progressively leveled off with increasing landfill age. $\mathrm{BOD}_{5} / \mathrm{TKN}$ ratio and $\mathrm{C} / \mathrm{N}$ ratio were also getting reduced with increasing landfill age, showing that the microbial degradation rate for organic nutrients is limited while ratios of carbon to nitrogen decrease. This happens similarly for VSS/FSS ratio. An increasing $\mathrm{pH}$ value, with increasing landfill age, due to biological decomposition of organic nitrogen to ammonia nitrogen has been also observed (Chen, 1996).

\subsubsection{Shredded tires - applicability for attached growth}

Shredded tire is reasonably durable, insoluble, permeable and can provide more surface area than that of crushed stone / rock (Univ. of Manitoba, 2005). As huge 
amount of scrap tire generation is a growing concern, shredded tire chips could be easily available. While used as packing in several instances, it was noticed that shredded tires can maintain easy passage of air (Edil et al., 2004). Clogging is often experienced in trickling filter systems and this will be automatically minimized due to the high porosity of shredded tires or chips (Univ. of Manitoba, 2005). All these phenomena basically indicate suitability of shredded tires as filter media.

Biomass, as understood with regards to biological treatment, is a viscous, jelly like material containing bacteria. Primarily this needs to be sorbed and attached to tire chips as a slime layer. Adsorption is a characteristic of tires due to its components like rubber polymers and carbon black. These types of particles are used to adsorb organics from water (CIWMB, 2003). Therefore, growth of biomass on the tire surface is quite likely. Vinyl pyridine latex based adhesive, pliocord vinyl pyridine, a tire component, can make tire cohesive to other substances, especially metallic substances. It can be expected that slime layers (biomass) will attach to the tire surface. Presumably these layers are subjected to natural sloughing, provided that sorbed organic compounds are biologically decomposed from time to time.

\section{Recent applications}

An experimental study was conducted to determine nitrification kinetics for synthetic leachate and landfill leachate (Clabaugh, 2001). One of the three biofilm columns in his experiment was packed with shredded tire chips; all three columns were seeded with organisms by pouring a mixture of the feed solution and nitrifiers on top of the media in each column. A nitrifying biomass was established after recirculating that feed solution for two weeks. The purpose of using different media was to examine the efficiency of media in supporting ammonia removal. Although wood chip media (77-87\%) was the best performer, efficiency of tire chips (20-62\%) was also reasonably good (Clauaugh, 2001). 
It has been shown that scrap tire has been used as a support medium in anaerobic-aerobic sequential biofilm reactors to treat industrial wastewater containing DCP (Shin et al., 1999). The main objective of their study was to determine the capacity of scrap tires to sorb DCP and CP. One reactor packed with tire chips s operated under anaerobic conditions for reductive dechlorination and the other under aerobic conditions for dechlorination of monochlorophenol. Mixed liquor suspended solids (MLSS), biomass concentration attached on tire chips, influent and effluent-COD were measured on a routine basis. Biofilm was formed on tire chips within 2 weeks time and no inhibitory effect of tire chips was noticed when used as the biofilm reactor media. COD removal rates reached more than $80 \%$ after 2 days (Shin et al., 1999). DCP was completely degraded in the anaerobic reactor and $70 \% \mathrm{CP}$ was removed in the aerobic biofilm reactor. Sorption capacity of tire chips for DCP and CP was estimated to be approximately 0.04 to $0.3 \%$ compared to that of granular activated carbon (Shin et al., 1999).

\subsubsection{Treatability of landfill leachate}

Evaluation of a treatment system for leachate must include consideration for the large temporal fluctuations in the quantity and composition of leachate. Leachate quality from young landfills will differ from that of old landfill. Knowledge of the age of the landfill is of great importance for designing leachate treatment systems (Lo, 1996). As leachate treatment is one of the most difficult issues the solid waste industry faces, it is important to find a suitable treatment system for leachate. Because leachate has a high organic content, aerobic and anaerobic treatment systems have been put to use in treatment. Since the mid-80s trickling filter systems have brought enormous changes in this sector due to their advantages such as low cost, less maintenance, treatability and ease of operation. 


\subsubsection{Attached growth and trickling filter system}

The concept of flowing wastewater across some natural material for treatment is the basis of attached growth processes (NESC, 2004). This entails wastewater to be in contact with natural microbial growths attached to the surfaces of the supporting media (Yang, 2002). Wastewater treatment systems such as trickling filters, roughing filters and rotating biological contactors are aerobic attached growth biological systems. The trickling filter is a packed bed reactor which is subjected to "trickling" of liquid over a packing media. Stone pieces, plastics and wood chips are normally used as the media and thereby a relatively a large surface area is generated within the system. Thus aerobic biofilters such as trickling filter systems are among the most efficient attached growth process for wastewater having a high organic content.

\subsubsection{Packing media for trickling filter system}

The types of packing in common use are classified into two groups, "conventional" or mineral / stone media and recently developed specially fabricated media, made from plastics. The modern trickling filter consists of a bed of highly permeable media to allow wastewater to trickle down easily (Yang, 2002). The media bed is probably the most important component for treatment of wastewater because it provides the surface area where the microorganisms grow, thus establishing a biofilm. Now-a-days there are several media options which include rocks, woods, and synthetic plastics in various shapes and sizes.

The standard size of stone used for packing is 40 to $50 \mathrm{~mm}$, giving a specific surface of 80 to $110 \mathrm{~m}^{2} / \mathrm{m}^{3}$ and a void ratio of 40 to $55 \%$ (Knox, 1985). The stones are stacked to form a bed of 2 to $3 \mathrm{~m}$ deep and the corresponding weight is about $1350-1550 \mathrm{~kg} / \mathrm{m}^{3}$ of the bed (Yang, 2002). Conventional filters consisting of rock packing has a maximum hydraulic loading of $0.5 \mathrm{gpm} / \mathrm{ft}^{2}$ and an expected $85 \%$ BOD removal efficiency. 
Specially fabricated packing media, such as plastic media, have been recently used for trickling filter systems for wastewater treatment. Plastic packings have very high void space, approximately $90 \%$. Another advantage is that these kinds of materials are very light, about one-tenth of the weight of the mineral media. All these parameters allowed the trickling filter system to tackle high hydraulic as well as organic loadings. Clogging problems have been eliminated in modern trickling filter systems using plastic packing material as filter media. The plastic material can be 20 to $25 \mathrm{~mm}$ thick polypropylene, rigid polyvinyl chloride or even polyethylene. The plastic packed filters can handle hydraulic loadings of 4 $\mathrm{gpm} / \mathrm{ft}^{2}$ and exhibit up to $90 \%$ BOD removal efficiency (Yang, 2002).

\subsubsection{Applicability of scrap tire as packing media}

Scrap vehicle tires are shredded to create tire chips or tire shreds. One distinctive advantage of tire chips is that void ratio is much less than that of the large sized tire shreds resulting in a lower compressibility of tire chips (Yang et al., 2002); hence, the rate of leachate trickling through the tire chip media is not likely to be hampered or prevented at all. The void space of tire shreds is much more than that of tire chips; this may lead towards leakage of organic matter into the treated effluent. This is supported by the fact that the permeability of tire shreds is much higher than tire chips. The permeability of tire chips, which is approximately $0.03 \mathrm{~cm} / \mathrm{s}$ (much higher than design performance criteria of 0.01 $\mathrm{cm} / \mathrm{s}$ ), is a good indication that tire chips are suited as filling material in landfill leachate collection systems (Gonzales et al., 1995). Hence, it is assumed that tire chips will be a good packing media in trickling filters. Considering the void space factor, it can be noted that total surface area imparted by tire chips will be much more than that of an equal volume of tire shreds. Tire crumbs, made out of tire chips, have more surface area than that of tire chips. As surface area is of importance for biomass growth, it makes tire chips and crumbs more desirable for using as packing media in trickling filter. Therefore, tire chips and tire crumbs may be effective for leachate treatment and this needs to be investigated. 


\subsubsection{Trickling filter - treatment process}

Trickling filters are aerobic and are used to treat biodegradable organic matter. They are also used to oxidize ammonia- $\mathrm{N}$ to nitrate- $\mathrm{N}$ in a process known as nitrification (Grady et al., 1999). The effluent flows downward and substrate is assimilated by the biomass, which is a microbial growth attached to the packing media. Conventional filters, consisting of rock packings have a maximum hydraulic loading of $0.5 \mathrm{gpm} / \mathrm{ft}^{2}$ and $85 \%$ BOD removal efficiency. The plastic packing filters can handle hydraulic loading of $4 \mathrm{gpm} / \mathrm{ft}^{2}$ and exhibit up to $90 \%$ BOD removal efficiency (Yang, 2002).

Microorganisms, attached to the filter media, reduce organic matter in the wastewater. The slime layer, which is basically a biological film, is full of microorganisms which adsorb the organic material. The thickness of the slime layer increases due to growth of microorganisms. Diffused oxygen and nutrients are consumed before they can penetrate the full depth of slime layer (Yang, 2002). As the slime layer continuously increases in thickness; adsorbed organic matter is continuously broken down before reaching the microbes near the media surface. Thus an anaerobic environment is created near the surface of the media. In such an environment, microbes near the surface enter into an endogenous phase of growth due to lack of organic material (Yang, 2002). Hence, as they start to die, the slime layer itself looses its ability to attach to the media surface. Wastewater washes off the slime layer, a process called sloughing and then a new layer starts to grow on the same surface (Yang, 2002).

Microbial respiration occurs due to oxygen and nutrient diffusion. Carbon dioxide and other by-products diffuse out of the slime into the flowing liquid. Thus a defined depth of aerobic strata is developed in the slime layer. Due to a nutrient and oxygen deficiency, layers below the aerobic stratum becomes anaerobic in nature. 
The underdrain system is basically a collection unit for treated effluent along with biosolids, the collected liquid and solids are then discharged into a settling tank (Yang, 2002).

\subsubsection{Leachate treatment by trickling filter}

Leachate treatment is one of the most difficult issues the solid waste industry faces. As leachate has very high organic content, aerobic/anaerobic treatment systems or a combination of aerobic and anaerobic treatment have been attempted in order to treat the leachate. However, some of the successful experimental studies incorporating trickling filter system are briefly presented below.

\section{Trickling filter pilot plant study (Knox, 1985):}

Results pertaining to removal of $\mathrm{BOD}_{5}$ and nitrification of ammonia from leachate by biological filter (trickling filter) pilot plants in United Kingdom were summarized and presented. Leachate used in this study came from a landfill at Pitsea, United Kingdom. Responsible factors for trickling filter performance include total organic loading, total surface loading, total kjeldahl nitrogen loading, total hydraulic loading, media depth, temperature, DO-concentration, $\mathrm{pH}$ of the wastewater, and the media type.

\section{Process performance}

$\mathrm{BOD}_{5}$ concentrations in the effluent from the filter were always below the discharge limit $(40 \mathrm{mg} / \mathrm{l})$. Removal efficiency for $\mathrm{BOD}_{5}$ was in the range of $75-$ $90 \%$. Ammonia removal was satisfactory. The highest ammonia removal rate achieved in the trickling filter was $309 \mathrm{mg} \mathrm{N} \mathrm{m}^{-2}$ day $^{-1}$ at $16^{\circ} \mathrm{C}$, similar to nitrification rates for sewage at similar temperatures.

The $\mathrm{BOD}_{5}: \mathrm{NH}_{3}-\mathrm{N}$ ratio was about 1:3, $\mathrm{BOD}$ as a fraction of total organic carbon (TOC) was small, hence while the author mentions that very little organic carbon was readily degradable, it seems that only the BOD portion of TOC was 
degradable. In another study, $\mathrm{BOD}_{5} / \mathrm{COD}$ ratio of the landfill leachate was found to be even below 0.1 and the author considered possible exclusion of biological treatment (Rodriguez et al., 2004). The author commented that attached growth systems would generally be simpler to operate than activated sludge systems for treatment of leachate with such characteristics.

\section{Limitations envisaged}

- Precipitation of inorganic solids creates clogging and scaling in the pipelines. This problem often happens while treating high strength leachate.

- Difficulty due to extreme fluctuations in leachate production rate.

- Difficulty in handling biological filters without sufficient storage. This problem is often experienced during storm events, as rainfall is the main contributor for the generation of leachate.

\section{Nitrification of landfill leachate - Treatability Study (Clabaugh, 2001):}

This treatability study was carried out by simulated filter unit reactors to study the removal of ammonia from the leachate in Virginia Polytechnic Institute and State University, Virginia, USA. This experiment was carried out in five distinct phases as presented below,

Phase 1: Three types of media were examined, in a laboratory set up comprising biofilm columns, to see which was the most effective in supporting ammonia removal. The reactor containing wood chips had the highest removal efficiency $(77-87 \%)$, and the percentage removal was much higher for wood than for the rubber chips i.e. shredded tire chips (20-62\%) and plastic media (13-46\%). Wood chips were proven to be the most efficient media.

Phase 2: This analysis examined the effect of varied hydraulic loading rates on ammonia removal. A new media type, stable landfill refuse, was introduced into this study phase, along with other three media. The different media types were 
compared to see which type is most efficient in handling the varied hydraulic loadings and removing $\mathrm{NH}_{3}-\mathrm{N}$. There was less ammonia removal at higher flow rates, the wood (pine) media reactor removed $100 \%$ of the incoming $\mathrm{NH}_{3}-\mathrm{N}$ at the lowest flow of $1.85 \mathrm{~m}^{3} / \mathrm{day} / \mathrm{m}^{2}$. The author concluded that the main finding of this part of the study was that removal of $\mathrm{NH}_{3}-\mathrm{N}$ was higher at lower flow rates and wood chips were determined to be the best suited supporting media.

Phase 3: This part of the study focused on determining whether landfill leachate contained constituents that would disrupt nitrification. As oxygen demand can act as an inhibitor, leachate was recirculated through a pine wood media reactor to stabilize the COD. Results suggest that the tested landfill leachate does not contain constituents that will inhibit nitrification.

Phase 4: The important result from this part of the study was that oak wood media is more efficient than pine wood media for $\mathrm{NH}_{3}-\mathrm{N}$ removal.

Phase 5: Wood chips worked well for $\mathrm{NH}_{3}-\mathrm{N}$ removal, but did not seem to be an effective treatment process for the removal of COD. The author suggested that oxygen supply may be a factor. Additional studies are needed to determine design criteria for biodegradable COD in leachate using biofilms of natural materials.

\section{More examples:}

- Leachate from Boyertown Sanitary Landfill located near Gilbertsville, Montgomery County, PA, USA was introduced from a raw leachate storage lagoon to the bottom of the fixed film reactor (submerged trickling filter). The reactor was aerated utilizing aeration facilities. The media in combination with the aeration significantly reduced TOC levels. The system has run continuously with little maintenance or operator attention since August of 1985 (William et al., 2004). 
- A novel method for leachate treatment from landfills was developed based on purification of the leachate with the aid of a network of independent treatment units, named as in-situ purification units (ISPU). These units consist of a collecting well (CW) and a treatment well (TW), which is basically an aerated biofilter equipped with filling materials. This approach is a combination of aerobic and anaerobic processes. The aerobic process is taking place in aerated biofilters located in the body of the landfill. The anaerobic process is taking place through recirculation of the leachate. The main advantages of this method are the relative low operating cost, the flexibility and the simplicity of construction (Maliokas, 1999). 


\section{Chapter 3: Materials and Methods}

\subsection{Materials}

\subsubsection{Packing materials}

\section{Shredded tire chips and tire crumbs:}

Collection - Shredded tire chips and tire crumbs were collected from a shredding facility, named Trensept Automation Incorporation, located in the City of St. Catherines, Ontario. The size of the tire chips ranged between 12 to $50 \mathrm{~mm}$ and the size of tire crumbs ranged between 1.5 to $6.5 \mathrm{~mm}$.

Although an attempt was made to collect almost wireless tire chips, it was not possible because the above tire shredding facility was not able to supply wireless tire chips and no such other facility was available in Ontario.

Preparation - The tire chips and tire crumbs were thoroughly washed with distilled water and dried for 1 hour in an oven (at $105^{\circ} \mathrm{C}$ ) before use as packing media in trickling filter. It is noted that the polyester cords, used in tires, start to melt at about $400^{\circ} \mathrm{F}$.

Gravel collection: $1 / 2-3 / 4$ inch $(12-20 \mathrm{~mm})$ size gravel was collected from an available stock of gravel in the Civil Engineering Building, Ryerson University to provide $10 \mathrm{~cm}$ gravel packing at the bottom of the two trickling filter units. 


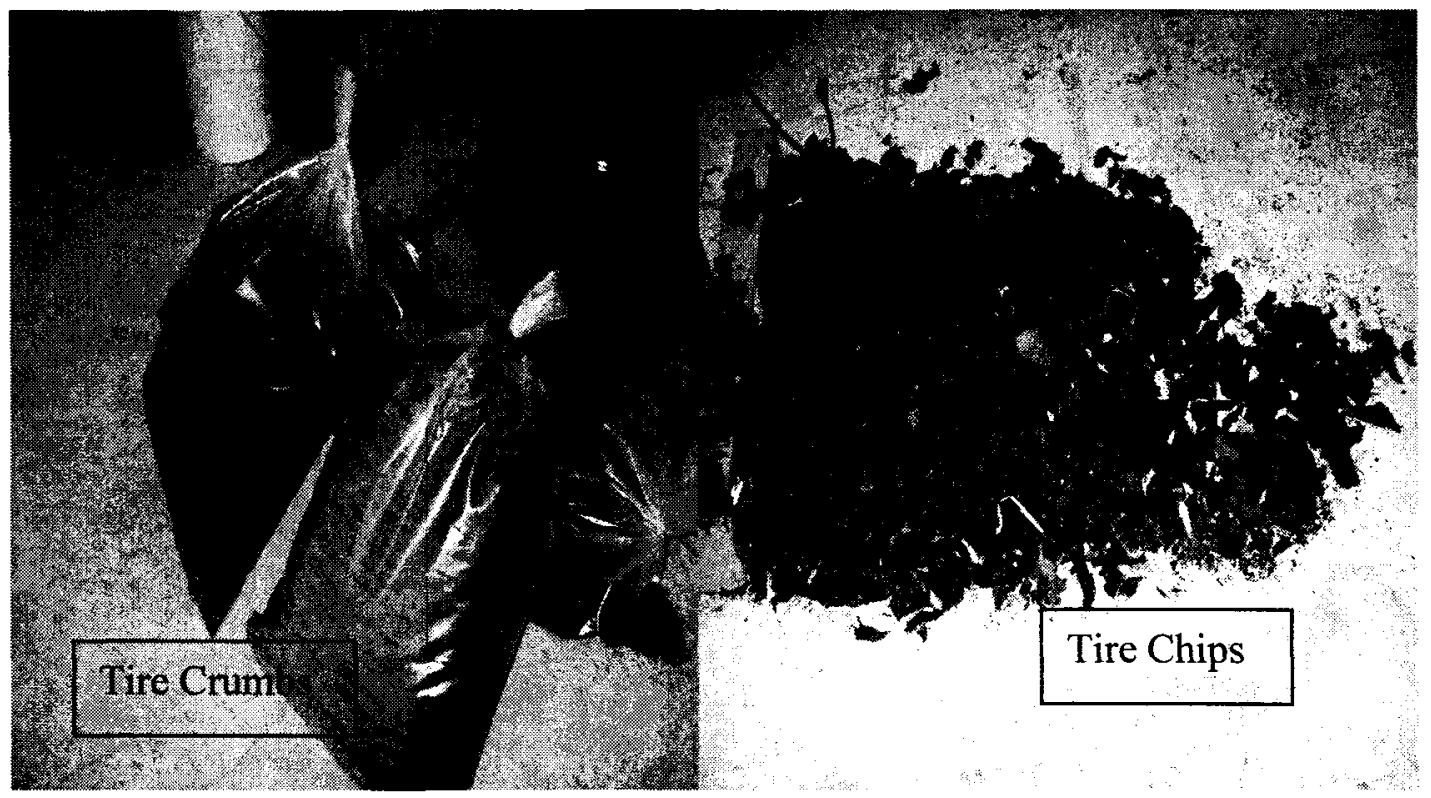

\section{Tire crumbs in the plastic bags and tire chips over a particular area prior to washing}

Landfill leachate collection: Leachate from the Keele Valley Landfill (KVL) near the City of Toronto, was collected from time to time for these experiments. This landfill is about 20 to 25 years old. Treatment of this kind of leachate will give a unique opportunity to deal with an old stable leachate, enriched with organic compounds and significant inorganic matter.

\subsubsection{Synthetic leachate}

Preparation: A composition of synthetic leachate as presented in Table 1, was created. This composition is basically a modified version of the composition adapted by R. Kerry Rowe (Rowe et. al., 2002), adapted originally from Harpovic, 2001. 
Table 1: Composition of synthetic leachate (Modified from Rowe et. al., 2002)

\begin{tabular}{|c|c|c|}
\hline SI. & Synthetic leachate components & Per 1 Liter \\
\hline 1. & Acetic acid & $7 \mathrm{ml}$ \\
\hline 2. & Propionic Acid & $5 \mathrm{ml}$ \\
\hline 3. & n-Butyric acid & $1 \mathrm{ml}$ \\
\hline 4. & $\mathrm{~K}_{2} \mathrm{HPO}_{4}$ & $30 \mathrm{mg}$ \\
\hline 5. & $\mathrm{KHCO}_{3}$ & $312 \mathrm{mg}$ \\
\hline 6. & $\mathrm{~K}_{2} \mathrm{CO}_{3}$ & $324 \mathrm{mg}$ \\
\hline 7. & $\mathrm{NaCl}$ & $1440 \mathrm{mg}$ \\
\hline 8. & $\mathrm{NaNO}_{3}$ & $50 \mathrm{mg}$ \\
\hline 9. & $\mathrm{NaHCO}_{3}$ & $3012 \mathrm{mg}$ \\
\hline 10. & $\mathrm{CaCl}_{2}$ & $2882 \mathrm{mg}$ \\
\hline 11. & $\mathrm{MgCl}_{2} 6 \mathrm{H}_{2} \mathrm{O}$ & $3114 \mathrm{mg}$ \\
\hline 12. & $\mathrm{MgSO}_{4}$ & $156 \mathrm{mg}$ \\
\hline 13. & $\mathrm{NH}_{4} \mathrm{HCO}_{3}$ & $2439 \mathrm{mg}$ \\
\hline 14. & $\mathrm{CO}\left(\mathrm{NH}_{2}\right)_{2}$ & $695 \mathrm{mg}$ \\
\hline 15. & Trace metal solution & $1 \mathrm{ml}$ \\
\hline 16. & $\mathrm{NaOH}$ & To titrate to pH 7.0 \\
\hline 17. & $\mathrm{Tap} \mathrm{water}$ & To make 1 liter \\
\hline
\end{tabular}

As this research work was focused on organic removal efficiency, all other components, except zinc sulphate and copper sulphate, as adapted by R. K. Rowe (Rowe et al., 2002), have been ignored in favour of a trace metal solution. The composition of the trace metal solution is as presented below. 
Table 2: Composition of Trace Metal Solution

(Modified from Rowe et al., 2002)

\begin{tabular}{|c|c|c|}
\hline SI. No. & Components of trace metal solution & Per 1 Liter \\
\hline 1. & $\mathrm{ZnSO}_{4} .7 \mathrm{H}_{2} \mathrm{O}$ & $50 \mathrm{mg}$ \\
\hline 2. & $\mathrm{CuSO}_{4} .5 \mathrm{H}_{2} \mathrm{O}$ & $40 \mathrm{mg}$ \\
\hline 3. & $96 \% \mathrm{H}_{2} \mathrm{SO}_{4}$ & $1 \mathrm{ml}$ \\
\hline 4. & Distilled water & To make 1 Liter \\
\hline
\end{tabular}

\subsubsection{Trickling Filter Pilot-plant}

Trickling filters are classified as fixed film filtration systems. A pilot-plant trickling filter system comprising two trickling filter units was installed. These two units were arranged in order to conduct leachate treatment using tire chips and tire crumbs as packing media. For the purpose of this report, these have been named as TF1 (trickling filter packed with tire chips) and TF2 (trickling filter packed with tire crumbs). Each trickling filter unit was comprised of fixed distributor arms, packed beds of tire chips or tire crumbs with gravel packing underneath, a drainage outlet, a common holding tank (for raw leachate), an influent pump, two treated effluent tanks and an air supply system with all other necessary components, as detailed out in appendix 2 . 


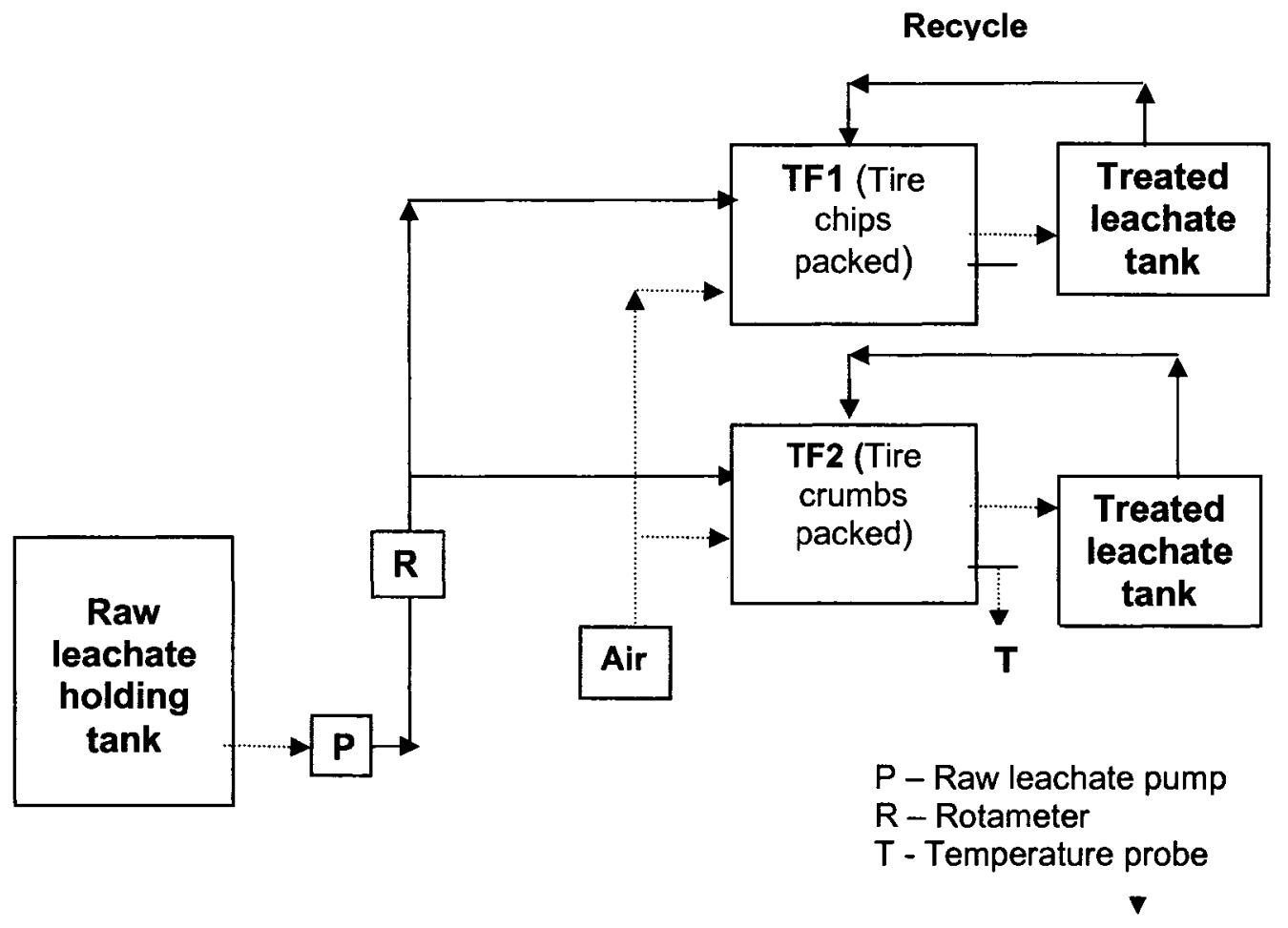

Fig. 1: Schematic diagram of Trickling Filter pilot-plant

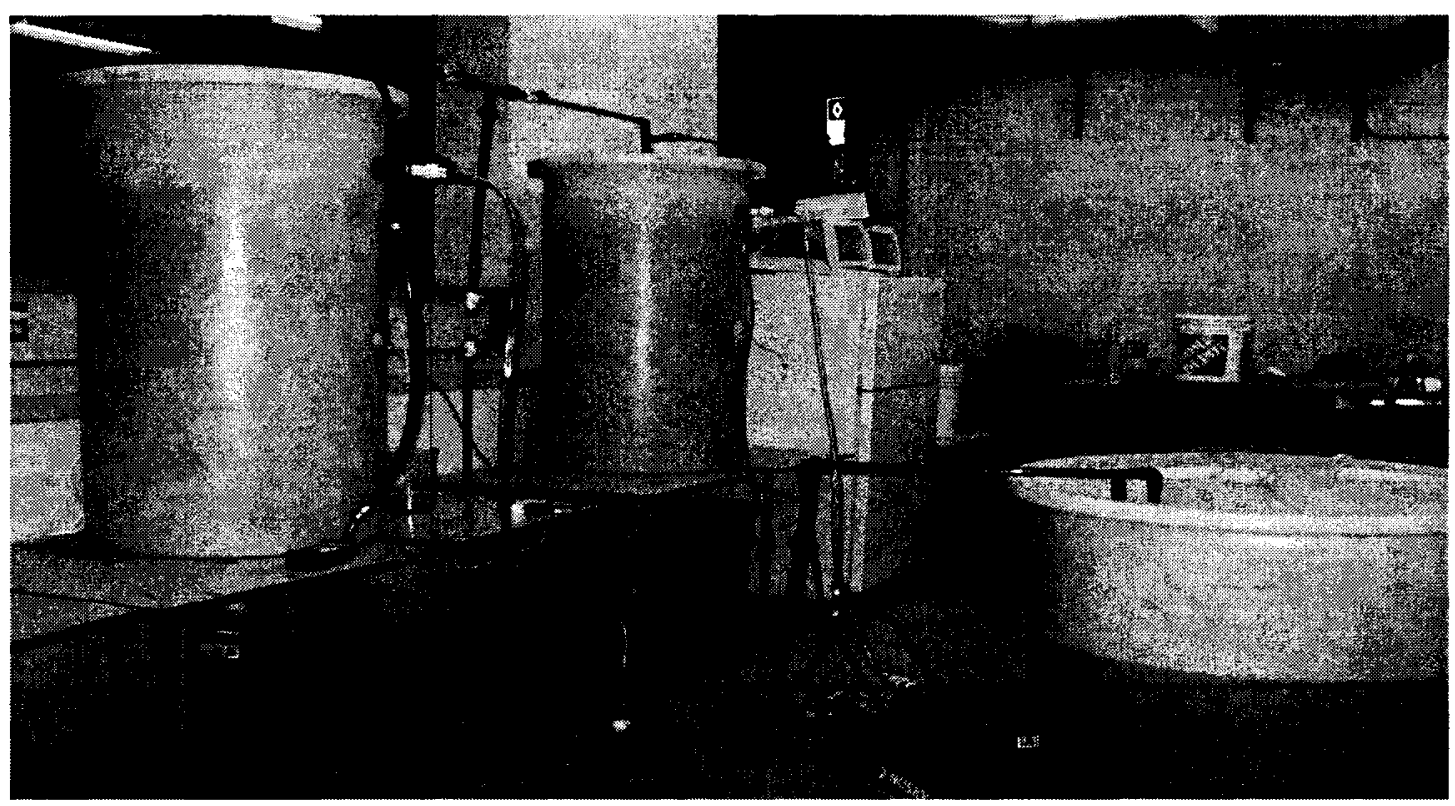

Trickling filter pilot-plant in Geo-Environmental Laboratory, Civil Engineering Dept., Ryerson University, Toronto 


\subsection{Experimental methods}

\subsubsection{Preparation of influent}

Raw KVL leachate, diluted with tap water in a 50:50 ratio, was used as influent for Stages 1 and 2. As the leachate was enriched with high levels of organics and microorganisms, use of the landfill leachate into the system was carefully considered. In fact, it was planned to seed the trickling filters initially by feeding a moderate organic loading to avoid a sudden shock to the media. Once the packing media was acclimatized with the seed, KVL leachate was mixed with synthetic leachate, in a 50:50 ratio, and fed into the system during stage 3 . Then the slowly proportion of KVL leachate was reduced. During stage 4, KVL leachate was mixed with synthetic leachate in 25:75 ratio. When the system was stable with leachate friendly microorganisms, then synthetic leachate only was used as influent during stage 5 and 6 . It was observed that the characteristics of the KVL leachate fluctuated within a broad range. Mixing of both type of leachate and the reduction of the KVL leachate portion gradually, were performed to transform this pilot-plant into a stable system for synthetic leachate finally.

\subsubsection{Trickling filter set-up and operation}

Two $1.28 \mathrm{~m}$ high PVC tanks of $0.6 \mathrm{~m}$ diameter each were converted into two trickling filter units. Total packing in each filter comprised $0.91 \mathrm{~m}$ of the tire chips / tire crumbs packing material with $0.1 \mathrm{~m}$ of gravel packing below. A fixed distributor arm was housed within the available space at the top. A void space of $0.20 \mathrm{~m}$ was maintained at the top of the distribution arm and a gap of $0.10 \mathrm{~m}$ was also maintained between distributor arm and top of the packing media. A $0.30 \mathrm{~m}$ void space and $0.15 \mathrm{~m}$ gap are required in ideal situation for trickling filters

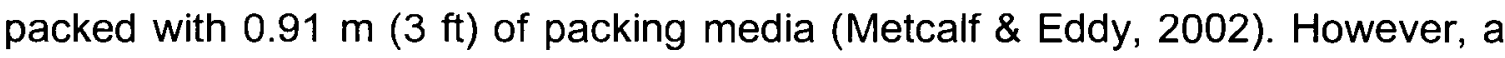
$1.40 \mathrm{~m}$ high PVC tank, as would be, was not available in the market. Therefore, the trickling filters were resized to some extent. A single centrifugal feed pump with a header line was used to distribute and disperse leachate into the two trickling filter units through the individual distribution arm in the respective filter 
towers. Raw leachate was passed through a rotameter where the flow rate was monitored continuously. The distribution arm allowed the leachate to trickle over the media into the filter towers. The pilot-plant was operated intermittently, for 10 hours every day during stages $1,2,3$ and continuously during stages 4,5 and 6 .

\section{Hydraulic loading}

Higher hydraulic loading rates may disrupt the system and increase the chance of leakage of organics through the filter. Recommended hydraulic loading for low or standard rate trickling filters is 1 to $4 \mathrm{~m}^{3} / \mathrm{m}^{2} /$ day, which is 20 to $82 \mathrm{gpd} / \mathrm{ft}^{2}$ (Metcalf and Eddy, 2002). $\mathrm{NH}_{3}-\mathrm{N}$ removal from landfill leachate was noticed to be potentially improved at low hydraulic loading rates and better organic removal would be achieved (Clabaugh, 2001). As overall treatment of landfill leachate, including $\mathrm{NH}_{3}-\mathrm{N}$ removal, has been targeted for this study, lower hydraulic loading rates between 1.47 to $3.91 \mathrm{~m}^{3} / \mathrm{m}^{2} / \mathrm{d}$ (30 to $80 \mathrm{gpd} / \mathrm{ft}^{2}$ ) were preferred. Factors such as shear velocity and sloughing depend on hydraulic loading (Metcalf \& Eddy, 2002). Considering all these points, hydraulic loading for this investigation was also kept in the lower range, between 2.25 to $4.50 \mathrm{~m}^{3} / \mathrm{m}^{2} / \mathrm{d}$ (46 to $92 \mathrm{gpd} / \mathrm{ft}^{2}$ ).

\section{Organic loading}

Organic loadings largely account for the rate of metabolism within the attached biomass (Metcalf \& Eddy, 2002). Initially, the organic loading rate was maintained between 0.28 to $0.61 \mathrm{~kg} \mathrm{BOD} / / \mathrm{m}^{3} / \mathrm{d}$ (17.5 to $38 \mathrm{lb} \mathrm{BOD}$ per day per $1000 \mathrm{ft}^{3}$ ) of media during the first two stages. This resembles the organic loading rate for a low-rate trickling filter. Then, the KVL leachate was mixed with synthetic leachate, the organic loading rate was increased automatically to 0.49 to $0.75 \mathrm{~kg}$ $\mathrm{BOD}_{5} / \mathrm{m}^{3} / \mathrm{d}\left(30.5-47 \mathrm{lb} \mathrm{BOD}_{5}\right.$ per day per $\left.1000 \mathrm{ft}^{3}\right)$. When the synthetic leachate proportion was increased in stage 4 , organic loading reached its highest level, ranging between 0.73 to $1.12 \mathrm{~kg} \mathrm{BOD} / \mathrm{m}^{3} / \mathrm{d}(45.5-70 \mathrm{lb} \mathrm{BOD}$ per day $/ 1000$ $\mathrm{ft}^{3}$ ); very similar to the organic loading rates for high rate trickling filters (Metcalf \& Eddy, 2002). 


\section{Air supply system}

It is better for aerobic trickling filters if at least $2 \mathrm{mg} / \mathrm{DO}$ is maintained (Knox, 1985) and the rate of air flow shall be minimum $1 \mathrm{ft}^{3} / \mathrm{ft}^{2} / \mathrm{min}$. for covered filters. Hence, in addition to free air passage an underdrain as air supply arrangement into the filter towers from an air compressor was made available during stages 1 and 2. Unfortunately, the air compressor broke down during the later half of stage 2 , and a new small ventilation fan was bought. As the ventilation fan supplied lot more air than was required for the trickling filter, it was used with a timer which was set for half-an-hour intervals. Also the air supply valves were throttled to ensure the required air supply into the system from stage 3 onwards. As the DO level in both the filters was maintained between 2.5 and $5 \mathrm{mg} / \mathrm{l}$ and the $\mathrm{pH}$ stabilized between 8 to 8.5 , it is believed that air supply system to both the trickling filters was adequate.

\section{Biomass attachment monitoring}

Initially tire chips and tire crumbs were left in the column, with leachate trickling through them continuously for a 3 week period, to allow a colony of microorganisms to grow on the tire chip assuming that the microorganism growth period takes about 2 to 3 weeks time, based on biomass formation achieved in 2 weeks time on tire chips (Shin et al., 1999). Biomass attachment onto the tire chips and crumbs and sloughing of the biomass was quantitatively monitored throughout the experiment. A 1 to $2 \mathrm{~mm}$ thick biomass, as measured by an electronic digital caliper, was observed on tire chips throughout the study period.

\section{Treated effluent holding tank}

Some biosolids were collected through the drainage outlet of the two trickling filter units from time to time. Therefore, a holding tank for the treated effluent is a necessity. Initially there was one treated effluent holding tank, but since stage 2 , the pilot-plant was bifurcated and performance of tire chips and tire crumbs was monitored separately. A layer of solids, deposited at the bottom of each tank, 
was observed during each stage. Clear samples from the top of each tank were collected for laboratory analysis.

\section{Testing and Analysis}

Grab samples for raw leachate from a common holding tank and treated effluent samples, from the treated effluent tanks, were collected from time to time. Those samples were analyzed for $\mathrm{BOD}_{5}$ at $20^{\circ} \mathrm{C}, \mathrm{COD}, \mathrm{NH}_{3}-\mathrm{N}$, TSS and TS. In order to measure each parameter, detailed experimental procedures according to "Standard Methods (1998)" were followed. There are several procedures available in Standard Methods for ammonia testing; but the "Phenate Method", as described under item no. $4500-\mathrm{NH}_{3} \mathrm{~F}$. in Standard Methods, 1998 was followed for $\mathrm{NH}_{3}-\mathrm{N}$ test. The reason for choosing this procedure is that total ammonia nitrogen, which includes both unionized ammonia and ionized ammonia, can be measured by this method with less error and this procedure is also less complicated. Available experimental facilities in the Environmental Laboratory, Civil Engineering Department were used for analysis purposes. A Lambda 20 spectrophotometer in the Ryerson University Analytical Centre was used for determining $\mathrm{COD}$ and $\mathrm{NH}_{3}-\mathrm{N}$ values of the samples. The Temperature of the filter towers and the $\mathrm{pH}$ of the treated effluent were recorded daily. The dissolved oxygen of the influent in the holding tank and effluent in the treated effluent tanks were also monitored periodically. 


\section{Chapter 4: Results and Discussion}

\subsection{Results and Discussion}

Keele valley landfill (KVL) leachate was initially diluted with fresh tap water in 1: 1 ratio and used as influent for stage 1 and stage 2 . While leachate was collected from the $\mathrm{KVL}$, the initial $\mathrm{pH}$ of the leachate at the collection point was $7.90 . \mathrm{BOD}_{5}$ and COD values of the KVL leachate were $2004 \mathrm{mg} / \mathrm{l}$ and $19950 \mathrm{mg} / \mathrm{l}$, respectively. The $\mathrm{BOD}_{5}$ to $\mathrm{COD}$ ratio of $\mathrm{KVL}$ leachate was 0.10 . However, initially diluted leachate was used to provide a moderate organic loading. The entire experiment was conducted in six stages for different durations. Two trickling filters, each of $600 \mathrm{~mm}$ in diameter, were packed with tire chips (TF1) and tire crumbs (TF2), respectively. All the stages are detailed in the following table. Flow rates maintained for this experiment were in the range of 0.6 to $1.60 \mathrm{lpm}(0.13$ to $0.35 \mathrm{gpm}$ ); range of hydraulic loading rate was 1.47 to $4.50 \mathrm{~m}^{3} / \mathrm{m}^{2} / \mathrm{d}$ (30 to 92 $\mathrm{gpd} / \mathrm{ft}^{2}$ ) for both the trickling filter units. This basically resembles a low rate trickling filter. Hydraulic loadings were alternatively set for two trickling filters during last two stages. Details are provided in table 3. 
Table 3: Details of stages adapted for trickling filter pilot-plant study

\begin{tabular}{|c|c|c|c|c|c|c|}
\hline $\begin{array}{c}\text { Stage } \\
\text { No. }\end{array}$ & Days & Influent & $\begin{array}{l}\text { Type of } \\
\text { Operation with } \\
\text { recirculation }\end{array}$ & $\begin{array}{c}\text { Flow Rate } \\
\text { for } \\
\text { Trickling } \\
\text { Filters }\end{array}$ & $\begin{array}{c}\text { Hydraulic } \\
\text { Loading rate } \\
\text { for Trickling } \\
\text { filters }\end{array}$ & $\begin{array}{c}\text { Organic } \\
\text { loading rate } \\
\text { for Trickling } \\
\text { filters }\end{array}$ \\
\hline 1 & 21 & $\begin{array}{l}\text { Diluted KVL } \\
\text { leachate }\end{array}$ & $\begin{array}{l}\text { Intermittent } \\
\text { (10 h / day) }\end{array}$ & $\begin{array}{lr}0.9 & -1.60 \\
\text { liter } & \text { per } \\
\text { min. } & \end{array}$ & $\begin{array}{l}2.25-4.0 \\
\mathrm{~m}^{3} / \mathrm{m}^{2} / \mathrm{d}\end{array}$ & $\begin{array}{l}0.28-0.50 \mathrm{~kg} \\
\mathrm{BOD}_{5} / \mathrm{m}^{3} / \mathrm{d}\end{array}$ \\
\hline 2 & 14 & $\begin{array}{l}\text { Treated } \\
\text { leachate from } \\
\text { Stage } 1\end{array}$ & $\begin{array}{l}\text { Intermittent } \\
\text { (10 h/ day) }\end{array}$ & $\begin{array}{lr}0.9-1.60 \\
\text { liter per } \\
\text { min. }\end{array}$ & $\begin{array}{l}2.25-4.0 \\
\mathrm{~m}^{3} / \mathrm{m}^{2} / \mathrm{d}\end{array}$ & $\begin{array}{l}0.35-0.61 \\
\mathrm{BOD}_{5} / \mathrm{m}^{3} / \mathrm{d}\end{array}$ \\
\hline 3 & 27 & $\begin{array}{l}\text { Diluted KVL } \\
\text { leachate and } \\
\text { synthetic } \\
\text { leachate } \\
(50: 50)\end{array}$ & $\begin{array}{l}\text { Intermittent } \\
(10 \mathrm{~h} / \text { day })\end{array}$ & $\begin{array}{ll}0.6-0.9 \\
\text { liter } & \text { per } \\
\text { min. } & \end{array}$ & $\begin{array}{l}1.47-2.25 \\
\mathrm{~m}^{3} / \mathrm{m}^{2} / \mathrm{d}\end{array}$ & $\begin{array}{l}0.49-0.75 \\
\mathrm{BOD}_{5} / \mathrm{m}^{3} / \mathrm{d}\end{array}$ \\
\hline 4 & 10 & $\begin{array}{l}\text { Synthetic } \\
\text { leachate and } \\
\text { KVL leachate } \\
(75: 25)\end{array}$ & Continuous & $\begin{array}{ll}0.6 & -0.9 \\
\text { liter } & \text { per } \\
\text { min. } & \\
\end{array}$ & $\begin{array}{l}2.93-4.50 \\
\mathrm{~m}^{3} / \mathrm{m}^{2} / \mathrm{d}\end{array}$ & $\begin{array}{l}0.73-1.12 \\
\mathrm{BOD}_{5} / \mathrm{m}^{3} / \mathrm{d}\end{array}$ \\
\hline 5 & 8 & $\begin{array}{l}\text { Synthetic } \\
\text { Leachate }\end{array}$ & Continuous & $\begin{array}{ll}0.6 & \mathrm{lpm} \\
(\mathrm{TF} 1), & \\
0.9 & \mathrm{lpm} \\
(\mathrm{TF} 2) & \end{array}$ & $\begin{array}{l}2.93 \mathrm{~m}^{3} / \mathrm{m}^{2} / \mathrm{d} \\
(\mathrm{TF} 1), \quad 4.50 \\
\mathrm{~m}^{3} / \mathrm{m}^{2} / \mathrm{d} \\
(\mathrm{TF} 2)\end{array}$ & $\begin{array}{l}0.73 \\
\mathrm{BOD}_{5} / \mathrm{m}^{3} / \mathrm{d} \\
(\mathrm{TF} 1), \quad 1.12 \\
\mathrm{BOD}_{5} / \mathrm{m}^{3} / \mathrm{d} \\
(\mathrm{TF} 2)\end{array}$ \\
\hline 6 & 7 & $\begin{array}{l}\text { Synthetic } \\
\text { leachate }\end{array}$ & Continuous & $\begin{array}{ll}0.9 \quad & \text { lpm } \\
(T F 1), & 0.6 \\
\text { lpm (TF2) }\end{array}$ & $\begin{array}{l}4.50 \mathrm{~m}^{3} / \mathrm{m}^{2} / \mathrm{d} \\
(\mathrm{TF} 1), \quad 2.93 \\
\mathrm{~m}^{3} / \mathrm{m}^{2} / \mathrm{d} \\
(\mathrm{TF} 2)\end{array}$ & $\begin{array}{l}1.12 \\
\mathrm{BOD}_{5} / \mathrm{m}^{3} / \mathrm{d} \\
(\mathrm{TF} 1), \quad 0.73 \\
\mathrm{BOD}_{5} / \mathrm{m}^{3} / \mathrm{d} \\
(\mathrm{TF} 2)\end{array}$ \\
\hline
\end{tabular}

\section{$\mathrm{pH}$ and temperature in the pilot-plant}

$\mathrm{pH}$ in both of the trickling filter units stabilized between 8 to 9 . For the tire chip packing media, $\mathrm{pH}$ was between 8.30 and 8.60 for most of the time and for the 
tire crumbs the $\mathrm{pH}$-range was between 7.90 and 8.30 . The range of temperature for both of the filters was between $15^{\circ} \mathrm{C}$ to $22^{\circ} \mathrm{C}$. Obviously this is influenced by winter temperatures as the experiment was carried out during December to March. It is noted that the temperature of the tire crumb packed filter was a little higher than the tire chip packed filter. Less void space in the tire crumbs packing media hindered air passage through the crumbs. Consequently, temperatures inside the filter media might have increased to some extent. The activity of microorganisms could be also partially responsible for this. It is noted that, although $\mathrm{pH}$ decreased due to synthetic leachate use in the pilot-plant and also

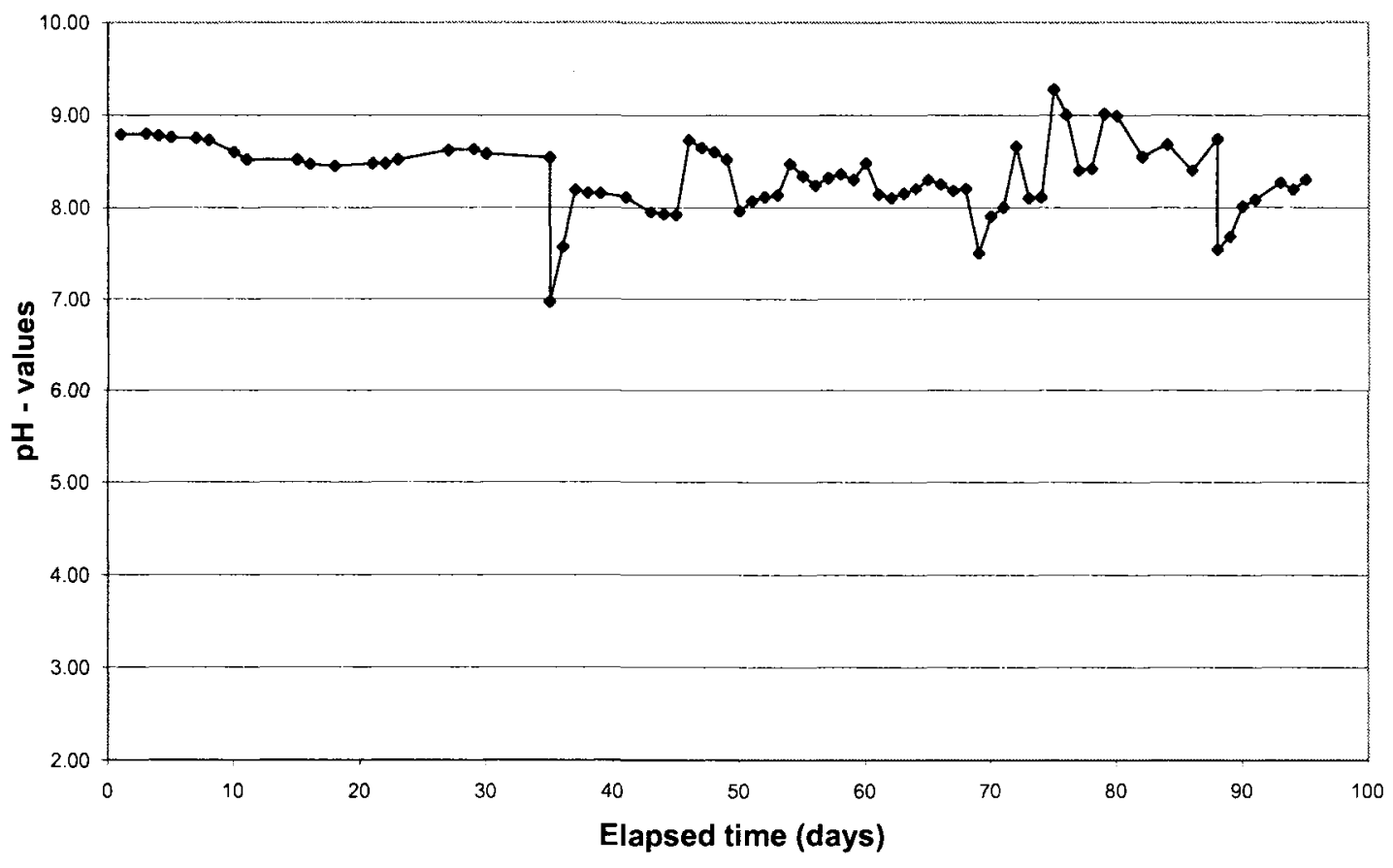

Fig.2: Variation of $\mathrm{pH}$-values for tire chips packed trickling filter

increased during $\mathrm{pH}$ correction, its tendency was to be stabilized in the range of 8.00 to 8.50 . This $\mathrm{pH}$ range is within the range of suitable $\mathrm{pH}$ for biological treatment by trickling filter (Metcalf \& Eddy, 2002). 


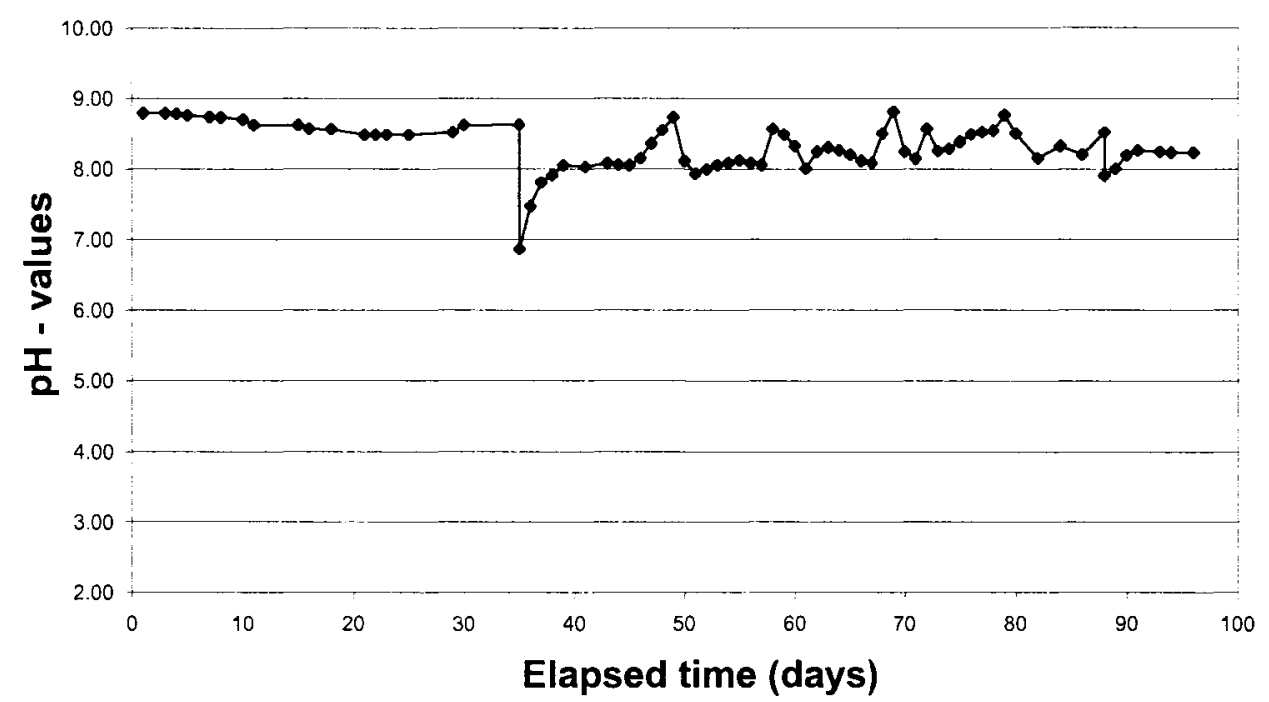

Figure 3: Variation of $\mathrm{pH}$-values for tire crumbs packed trickling filter

Similar patterns of $\mathrm{pH}$ were observed in treated effluent from the trickling filter packed with tire crumbs. Values of $\mathrm{pH}$ were observed in the range of 8.00 to 8.50 , even though this was lowered down to 6.97 because of synthetic leachate addition on the $35^{\text {th }}$ day during stage 3 .

\section{Dissolved oxygen in the pilot-plant}

Except for a few days during stage 3 and just after the change over from stage to stage, dissolved oxygen (DO) was above $2 \mathrm{mg} / \mathrm{l}$ throughout the experiment. Due to lack of aeration, the DO level was below $2 \mathrm{mg} / \mathrm{l}$ during stage 2 . An increased DO level (8-9 mg/l) was observed during each change over between stages, which could be attributed to fresh leachate and / or fresh tap water use for preparation of the synthetic leachate. However, stable DO levels between 2.5 to $5 \mathrm{mg} / \mathrm{l}$ were observed during operation. 


\subsubsection{Facts and Figures}

Initially one common treated effluent tank was provided for TF1 (packed with tire chips) and TF2 (packed with tire crumbs) to monitor the performance of the pilotplant as a whole. After 21 days, TF1 and TF2 were separated and two different treated effluent tanks were provided to assess their performance separately and explore a comparison between the two types of tire media in a trickling filter treating landfill leachate. Organic removal and a comparison of tire materials being the primary objectives, have been stressed in the following results and discussion sections. Removal efficiencies and the requisite durations pertaining to $\mathrm{BOD}_{5}, \mathrm{COD}, \mathrm{NH}_{3} \mathrm{~N}$, total suspended solids and total solids of the grab samples collected from the treated effluent have been presented in Tables 4 and 5. It is important to note that some interesting bacteria and aquatic microorganisms were observed, in the film attached to tire chips and tire crumbs, using inverted electronic microscope in the laboratory. The main excerpts and expositions, based on the data obtained for the above parameters, have been presented graphically, compared and discussed in detail in section 4.1.2. 
Table 4: Stage-wise removal efficiencies for $\mathrm{BOD}_{5}, \mathrm{COD} \& \mathrm{NH}_{3}-\mathrm{N}$

\begin{tabular}{|c|c|c|c|c|c|c|c|}
\hline \multirow[b]{2}{*}{ 恋 } & \multirow[b]{2}{*}{$\overbrace{0}^{\infty}$} & \multicolumn{3}{|c|}{ TF1 (Tire Chips) } & \multicolumn{3}{|c|}{ TF2 (Tire Crumbs) } \\
\hline & & $\begin{array}{l}\mathbf{B O D}_{5} \\
(\mathrm{mg} / \mathrm{l})\end{array}$ & $\begin{array}{l}\text { COD } \\
(\mathrm{mg} / \mathrm{l})\end{array}$ & $\begin{array}{l}\mathrm{NH}_{3}-\mathrm{N} \\
(\mathrm{mg} / \mathrm{l})\end{array}$ & $\begin{array}{l}\mathrm{BOD}_{5} \\
(\mathrm{mg} / \mathrm{l})\end{array}$ & $\begin{array}{l}\text { COD } \\
(\mathrm{mg} / \mathrm{l})\end{array}$ & $\begin{array}{l}\mathrm{NH}_{3}-\mathrm{N} \\
(\mathrm{mg} / \mathrm{l})\end{array}$ \\
\hline 1 & 21 & $81 \%$ & $75.5 \%$ & $\begin{array}{l}15 \%, \\
7 \text { days }\end{array}$ & $81 \%$ & $75.5 \%$ & $\begin{array}{c}15 \%, \\
7 \text { days }\end{array}$ \\
\hline 2 & 14 & $33 \%$ & $69 \%$ & $67 \%$ & $47 \%$ & $69 \%$ & $67 \%$ \\
\hline 3 & 27 & $96 \%$ & $89.5 \%$ & $68 \%$ & $\begin{array}{c}92 \%, \\
26 \\
\text { days }\end{array}$ & $89.5 \%$ & $\begin{array}{c}63 \% \\
26 \text { days }\end{array}$ \\
\hline 4 & 10 & $33 \%$ & $16 \%$ & Negligible & $69 \%$ & $16 \%$ & Negligible \\
\hline 5 & 8 & $39 \%$ & $\begin{array}{c}13 \%, \\
2 \text { days }\end{array}$ & $45 \%$ & $56 \%$ & $\begin{array}{c}13 \%, \\
2 \text { days }\end{array}$ & $50.5 \%$ \\
\hline 6 & 7 & $58 \%$ & $\begin{array}{l}16.5 \%, \\
4 \text { days }\end{array}$ & $35 \%$ & $46 \%$ & $\begin{array}{l}16.5 \%, \\
4 \text { days }\end{array}$ & $58 \%$ \\
\hline
\end{tabular}

Note: On several occasions, mainly in the middle of stages 5 and 6 , there was no organic and ammonia removal, instead the toxicity level was raised to some extent. After immediate backwashing, the system again started to behave as before and organic removal efficiencies improved. Therefore, the maximum overall removal efficiencies, with specific reaction times, have been mentioned for each stage in the above table. 
Table 5: Stage-wise removal efficiencies for TSS and TS

\begin{tabular}{|c|c|c|c|c|c|}
\hline \multirow{2}{*}{ Stage } & \multirow{2}{*}{ Days } & \multicolumn{2}{|c|}{ TF1 (Tire Chips) } & \multicolumn{2}{|c|}{ TF2 (Tire Crumbs) } \\
\hline & & TSS (mg/l) & TS (mg/l) & TSS (mg/l) & TS (mg/l) \\
\hline 1 & 21 & $48 \%$ & $66 \%$ & $48 \%$ & $66 \%$ \\
\hline 2 & 14 & $70 \%$ & $38 \%$ & $76 \%$ & $33.5 \%$ \\
\hline 3 & 27 & $\begin{array}{c}98 \% \\
\text { (Within } 6 \\
\text { days) }\end{array}$ & $73 \%$ & $\begin{array}{c}83 \% \\
\text { (Within } 6 \\
\text { days) }\end{array}$ & $73 \%$ \\
\hline 4 & 10 & $\begin{array}{c}22 \% \\
\text { (Within } 8 \\
\text { days) }\end{array}$ & $15 \%$ & $\begin{array}{c}41 \%, \\
\text { (Within } 8 \\
\text { days) }\end{array}$ & $\begin{array}{c}12 \%, \\
\text { Within } 8 \text { days }\end{array}$ \\
\hline 5 & 8 & $\begin{array}{c}38 \% \\
\text { (Within } 4 \\
\text { days) }\end{array}$ & $\begin{array}{c}49 \%, \\
\text { (Within } 4 \\
\text { days) }\end{array}$ & $42 \%$ & Negligible \\
\hline 6 & 7 & $67 \%$ & $6 \%$ & $67 \%$ & $7 \%$ \\
\hline
\end{tabular}

Note: In the later half of Stage 3, clogging was noticed in the trickling filters. This became severe in stages 5 and 6 . Therefore, there was a spike in solids levels to some extent. After immediate backwashing, the system again started to behave as before and removal efficiencies improved. Therefore, the maximum overall solids removal efficiencies, with specific reaction times, have been mentioned for each stage in the above table.

The trickling filter units were operated as re-circulating batch reactors. Residence times for a single pass through TF1 and TF2 were 60 and 75 seconds respectively. However, the stage durations, as indicated in table 4 and 5 , were 
the overall batch reaction times. In most of the cases, the maximum removal of the leachate's organic content and ammonia was achieved within the reaction time. Hence, biofilm development and its sloughing might have occurred in those batches within the reaction time. This indicates that those reaction time periods may be closer to the optimum solids retention times (SRTs) for those stages. However, variations in $\mathrm{BOD}_{5}, \mathrm{COD}$ and $\mathrm{NH}_{3}-\mathrm{N}$ removal efficiencies for various reaction times in the stages are presented hereunder.

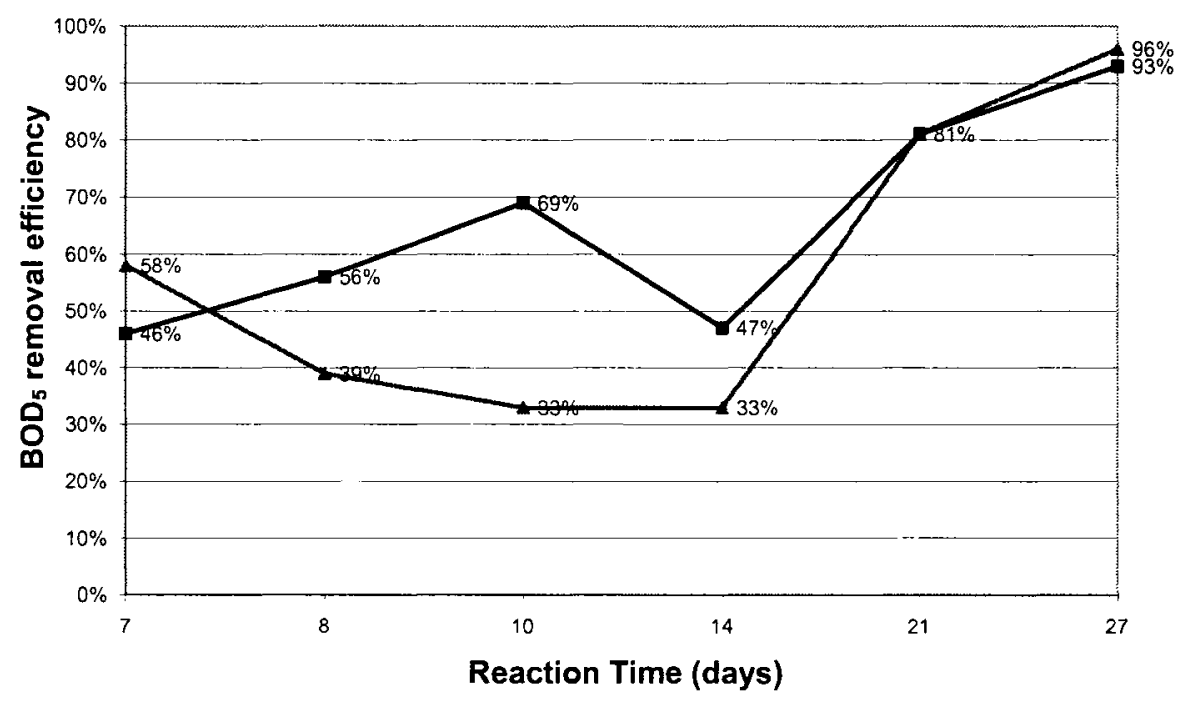

Tire Chips $\rightarrow$ - Tire Crumbs

Figure 4: Variation in $\mathrm{BOD}_{5}$ removal efficiency in varied reaction times

$\mathrm{A} \mathrm{BOD}_{5}$ removal of $81 \%$ was achieved within 21 days for stage 1 . It is evident from the above figure that the rate of BOD5 removal fluctuates within the first 14 days; but then, increases rapidly up to 21 days, and then declines. It seems that for biofilm attached to the tire materials started to loose control over the leachate after 21 days. 


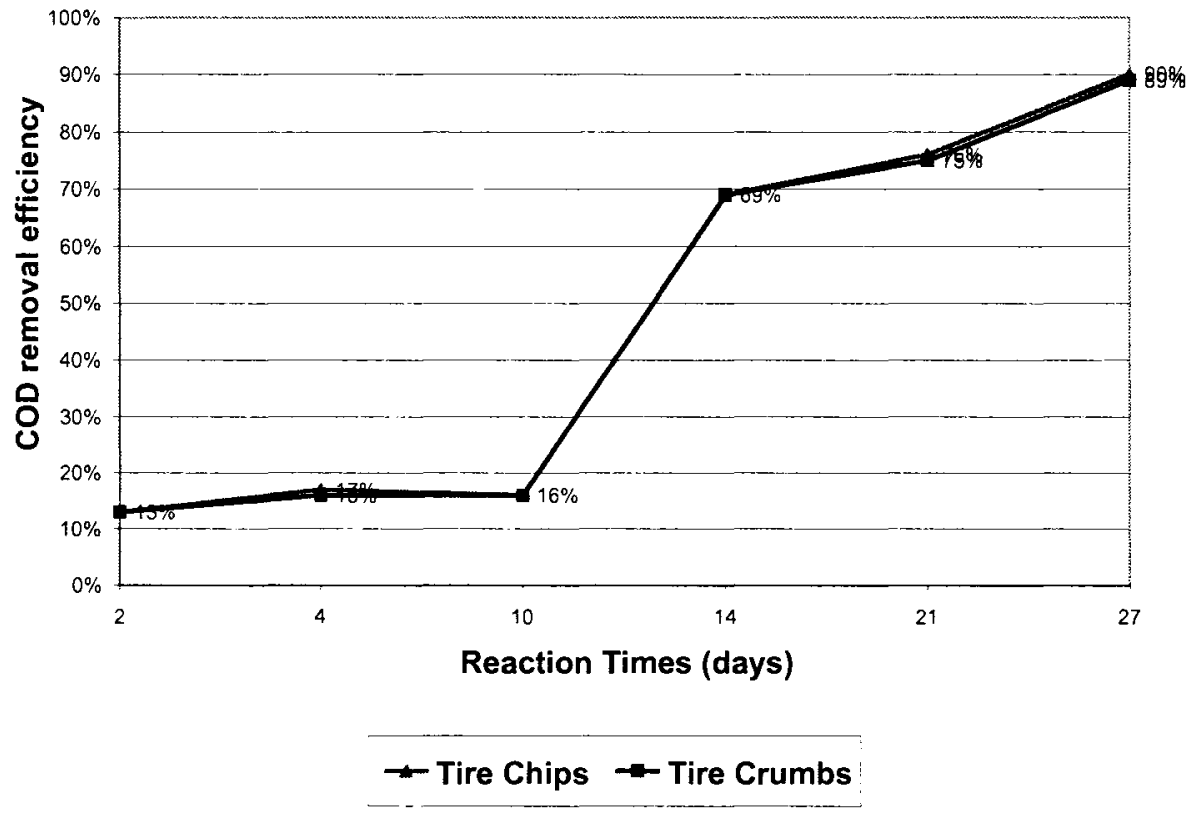

Figure 5: Variation in COD removal efficiency in varied reaction times

About $70 \%$ COD removal was achieved within 14 days at stage 2 ; it is understood from figure 5 that the COD removal efficiency declined after 14 days. However, the pattern of COD removal, between the $14^{\text {th }}$ and $21^{\text {st }}$ day was somewhat steady. Looking into both $\mathrm{BOD}_{5}$ and $\mathrm{COD}$ removal efficiencies, 21 days seem to be an appropriate solid retention time. 


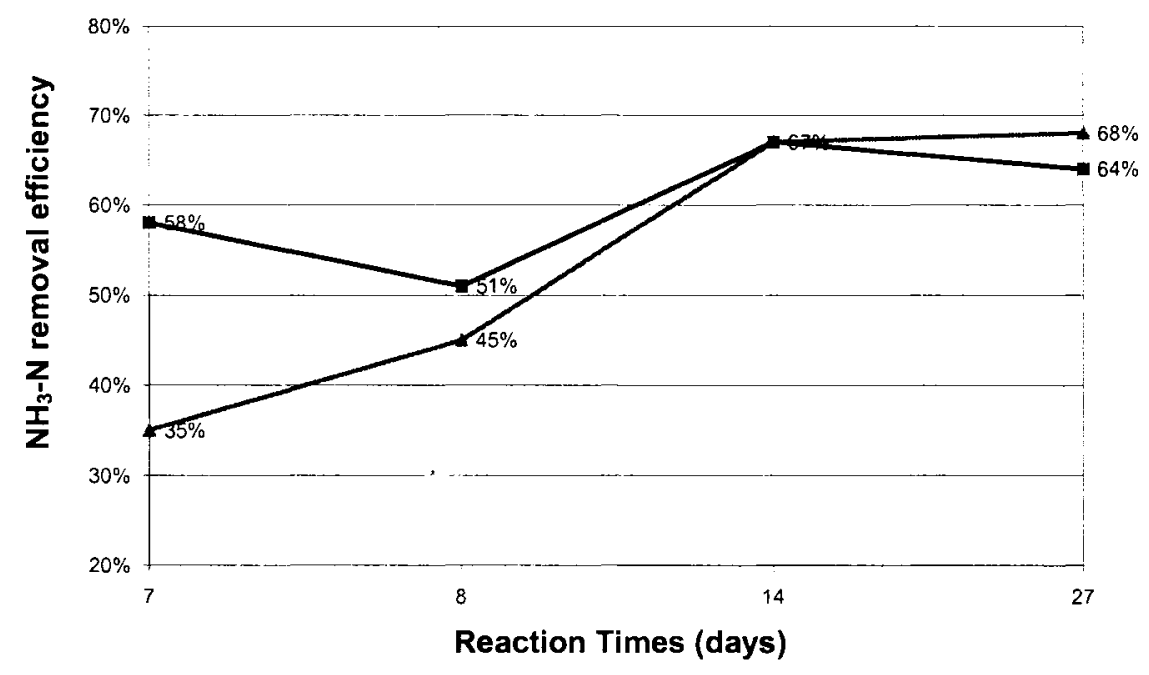

-Tire Chips $\quad \rightarrow$ Tire Crumbs

Figure 6: Variation in $\mathrm{NH}_{3}-\mathrm{N}$ removal efficiency in varied reaction time

No significant difference was observed in the pattern of ammonia nitrogen removal except for a little sag during the start of the operation in the case of tire crumbs packed filter. Ammonia removal was steady after 14 days, and continued up to 21 days. Finally, a declining tendency in the rate of removal was observed from both the packing media.

It is also evident from table 5 that better TSS and TS removals were achieved in stage 1 (21 days) and stage 3 (27 days). Another important fact is biofilm sloughing. As a matter of coincidence, it was noticed that biofilm sloughing from both the media occurred after every 21 days. Therefore, it can be said that a 21 day time period was an appropriate solids retention time (SRT) for the tire chips and tire crumbs packing media as understood from this experimental study. 


\subsubsection{Performance of trickling filter pilot-plant Stage 1 to Stage 6}

STAGE $1\left(1^{\text {st }}\right.$ to $21^{\text {st }}$ day):

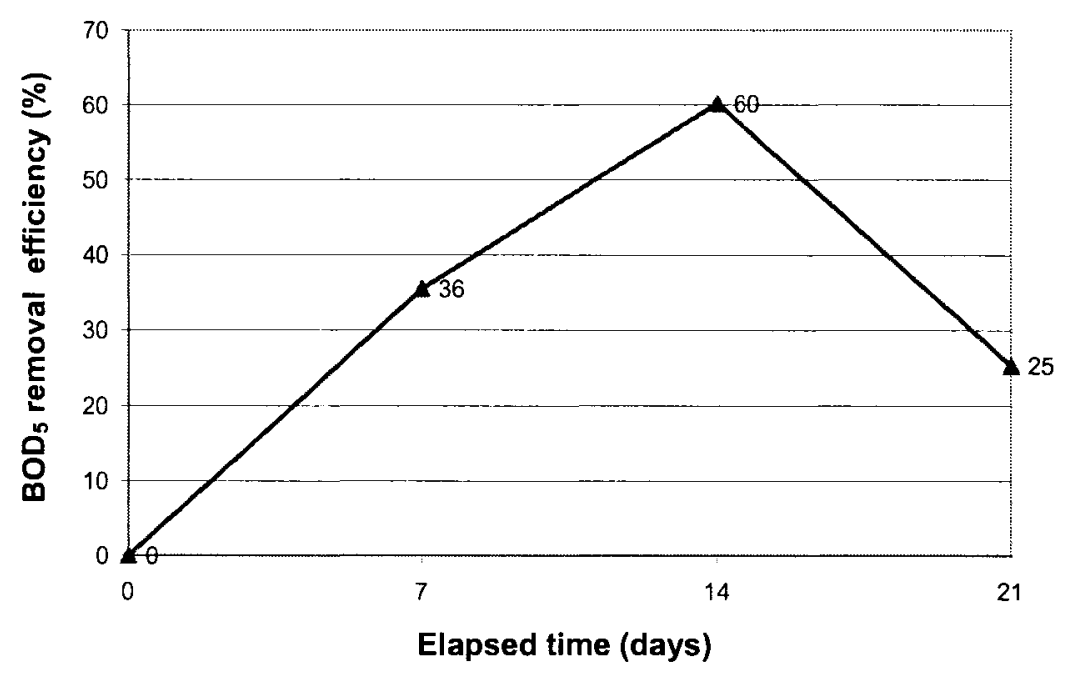

Figure 7: Variation in $\mathrm{BOD}_{5}$ removal efficiency in stage 1

\section{$\mathrm{BOD}_{5}$ removal:}

The treated effluent was collected from TF1 and TF2 in one tank. $\mathrm{BOD}_{5}$ removal efficiency was rapid up to 14 days of operation. The highest removal efficiency was $60 \%$ at the $14^{\text {th }}$ day, which resulted in $74 \%$ removal in total. This could be attributed to faster organic adsorption onto tire chips and tire crumbs in both the trickling filters initially. 


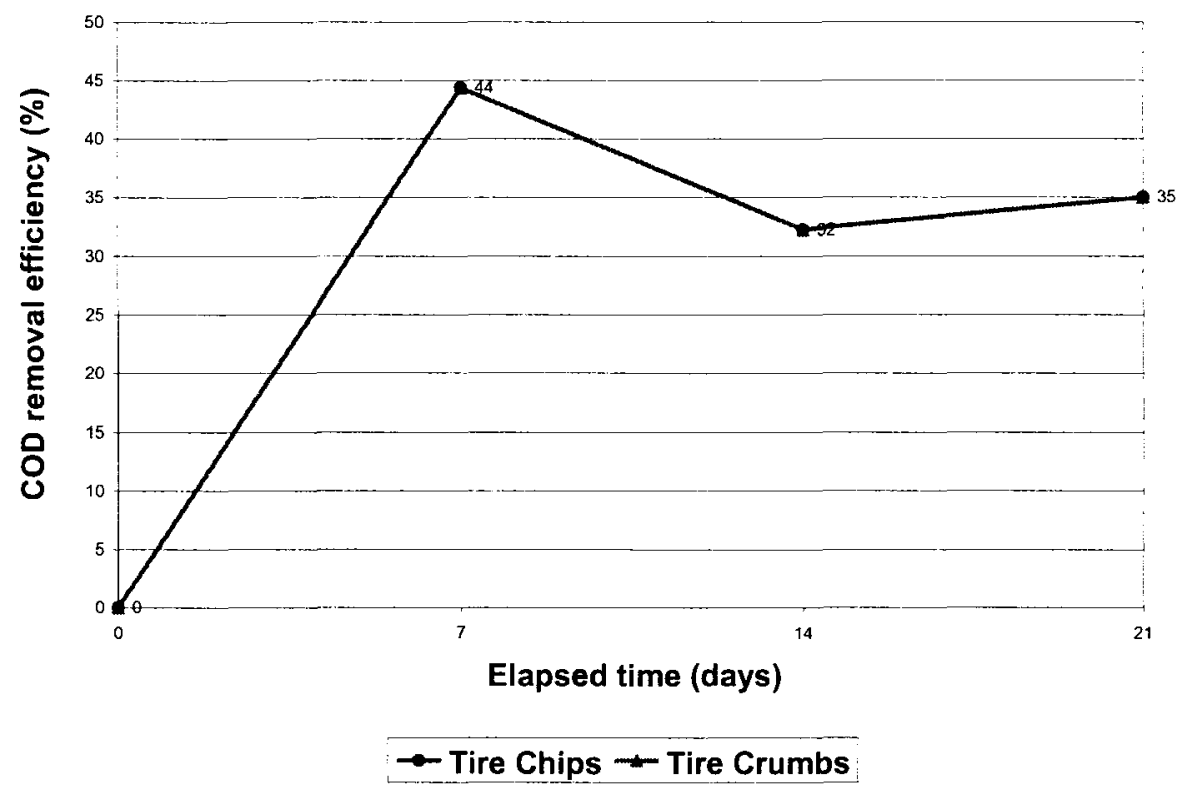

Figure 8: Variation in COD removal efficiency in stage 1

\section{COD removal:}

Initially COD removal efficiency was also rapid. A 44\% removal was obtained within the first 7 days, but it slowed down. The COD removal percentage was in the range of $32 \%-35 \%$ for the next 14 day period. The overall COD removal efficiency, using tire chips and tire crumbs, was $75 \%$ from the pilot-plant during this stage. Rapid $\mathrm{BOD}_{5}$ and $\mathrm{COD}$ removal during the initial seven days could be attributed to functionality of acclimatized biomass on the organic content of landfill leachate.

\section{$\mathrm{NH}_{3}-\mathrm{N}$ removal:}

There was no significant ammonia removal in this stage. 


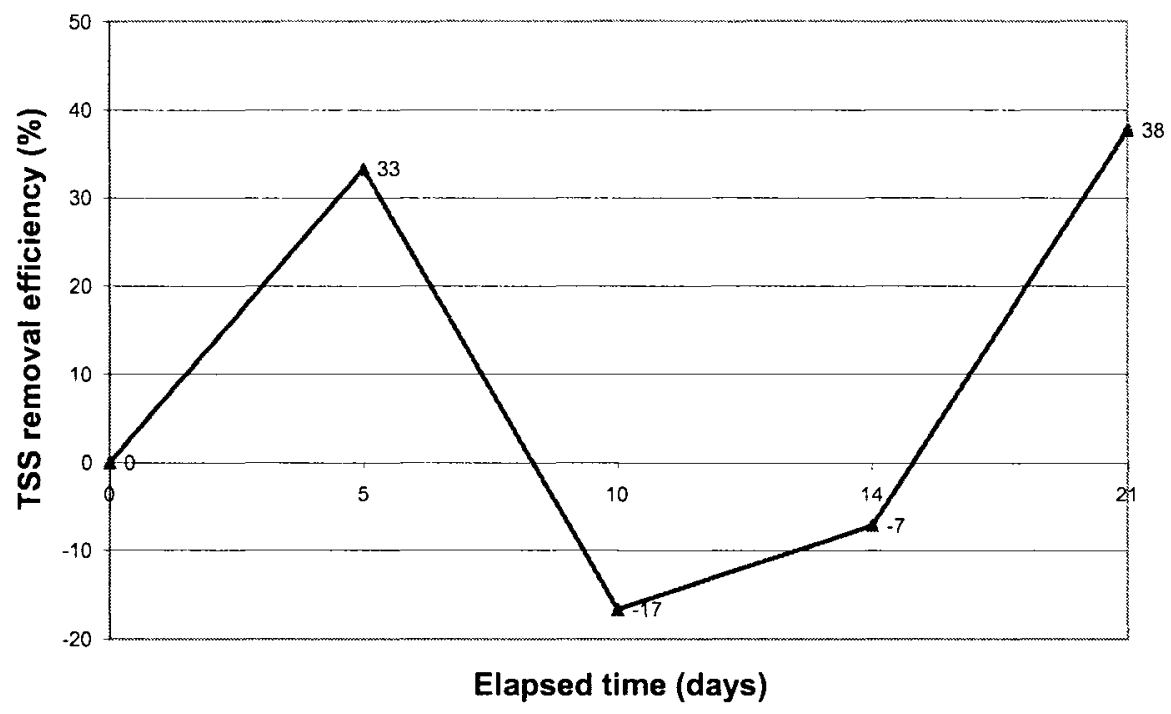

Figure 9: Variation in TSS removal efficiency in stage 1

\section{TSS and TS removal:}

Initially performance in this sector was good. A 33\% TSS removal was achieved from the pilot-plant within 5 days. But a 17\% increase in TSS was observed after another 5 days. This increase in suspended solids can be attributed to an initial flush-out from the trickling filters during this stage. Thereafter, TSS in the treated effluent started to decrease again rapidly. A 38\% TSS removal efficiency was achieved between $14^{\text {th }}$ to $21^{\text {st }}$ day. Whereas there was continuous TS removal from the treated effluent, a $66 \%$ TS removal was achieved in total during this stage. 
STAGE $2\left(21^{\text {st }}\right.$ to $35^{\text {th }}$ day $)$ :

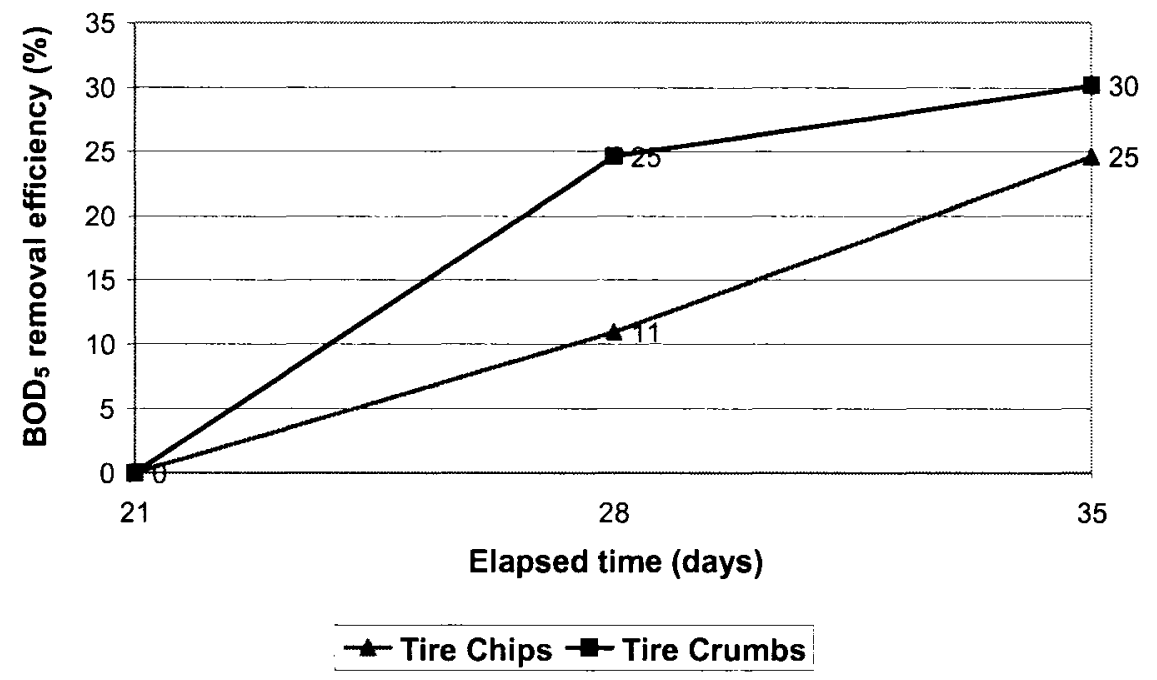

Figure 10: Variation in $\mathrm{BOD}_{5}$ removal efficiency in Stage 2

\section{$\mathrm{BOD}_{5}$ removal:}

From this stage onwards, the performance of tire chips and tire crumbs were monitored separately. The highest $\mathrm{BOD}_{5}$ removal efficiencies using tire chips and tire crumbs were $25 \%$ and $30 \%$, respectively. Whereas $\mathrm{BOD}_{5}$ removal using tire crumbs was $47 \%$. BOD removal efficiency was heavily affected by a lack in aeration during this stage. In fact, the tire chips packing media became weak enough to remove BOD. 


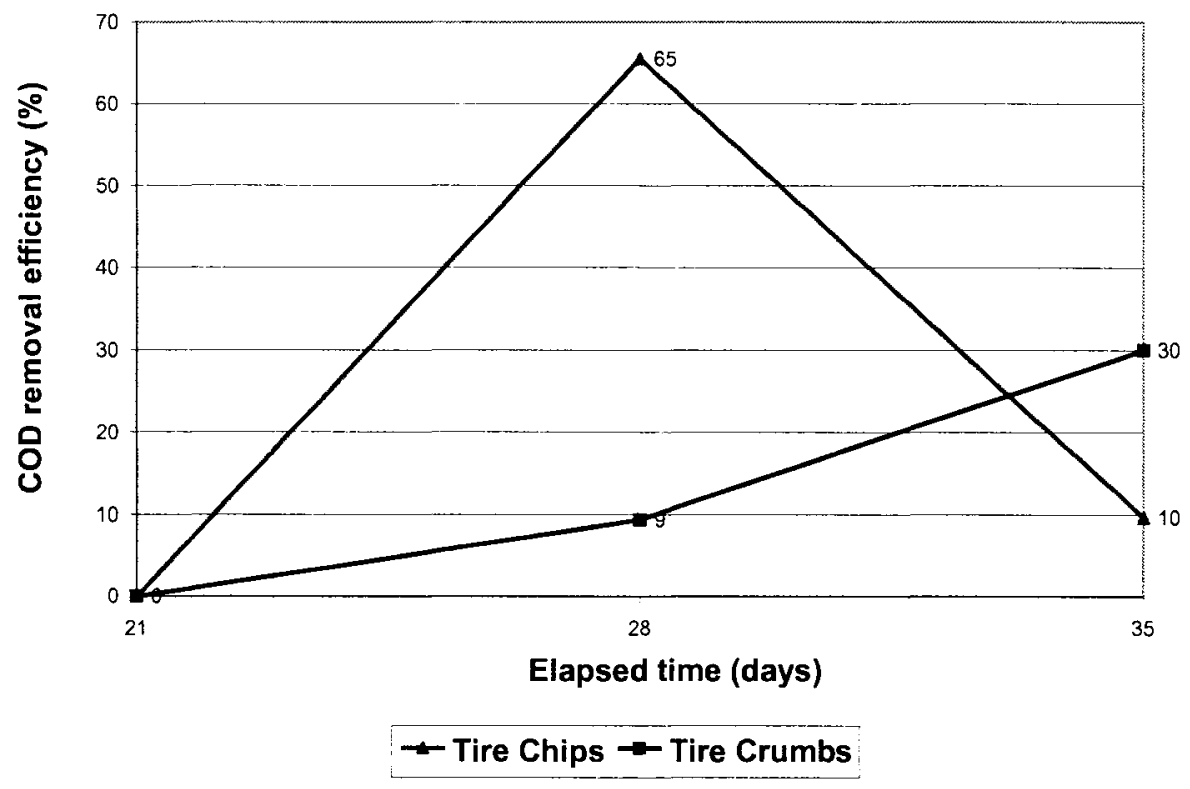

Figure 11: Variation in COD removal efficiency in stage 2

\section{COD removal:}

Although there was a lack of aeration, tire chips seem to perform better than tire crumbs in terms of COD removal efficiency. TF1 exhibited $65 \%$ COD removal within 7 days. Whereas TF2, packed with tire crumbs, exhibited only $30 \%$ COD removal. Hence, TF1 performed better than TF2 in terms of COD removal. A reason could be the better air passage through the higher void space in the tire chip media, even when there was a lack of aeration. This might have allowed the biomass in the entire tire chips media to utilize the little available air, and this was not readily possible within the tire crumb media due to less void space.

\section{$\mathrm{NH}_{3}-\mathrm{N}$ removal:}

TF1 and TF2 each exhibited about $67 \%$ removal in this sector. This could be attributed to better acclimatization of nitrifying microorganisms after 21 days in stage 1. A lack of aeration may have reduced dissolved oxygen in the system, but $\mathrm{pH}$ and temperature were still favorable. 


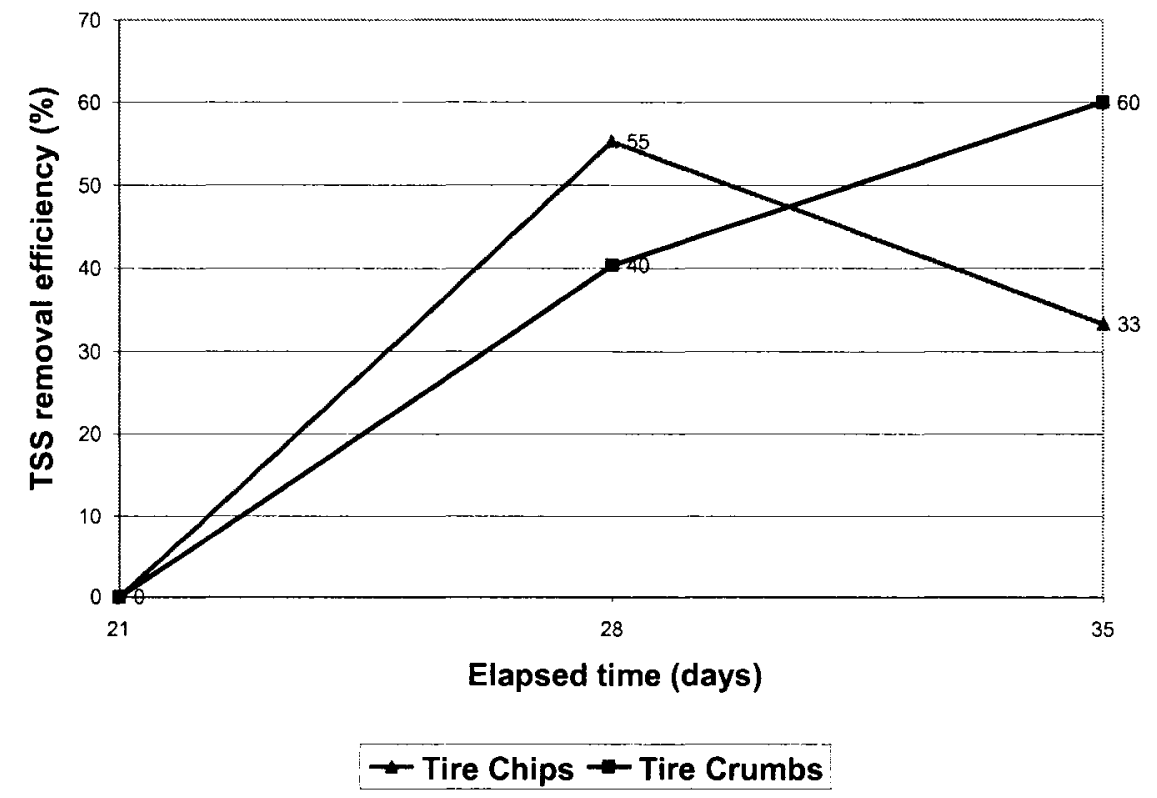

Figure 12: Variation in TSS removal efficiency in stage 2

\section{TSS and TS removal:}

A 55\% TSS removal from TF1 and 40\% TSS removal from TF2 were achieved within first 7 days in this stage. TF2 exhibited higher TSS removal (60\%) within the last 7 days. This is obviously better performance than in stage 1 .

Approximately $38 \%$ and $33 \%$ total solids removal were observed from TF1 and TF2 respectively after 14 days. Although there was an aeration deficiency, a consistent reduction of all types of solids was achieved. Moderate temperature, stable $\mathrm{pH}$ and minimum required dissolved oxygen might have acted as positive factors for solids removal. 
STAGE $3\left(35^{\text {th }}\right.$ to $62^{\text {nd }}$ day):

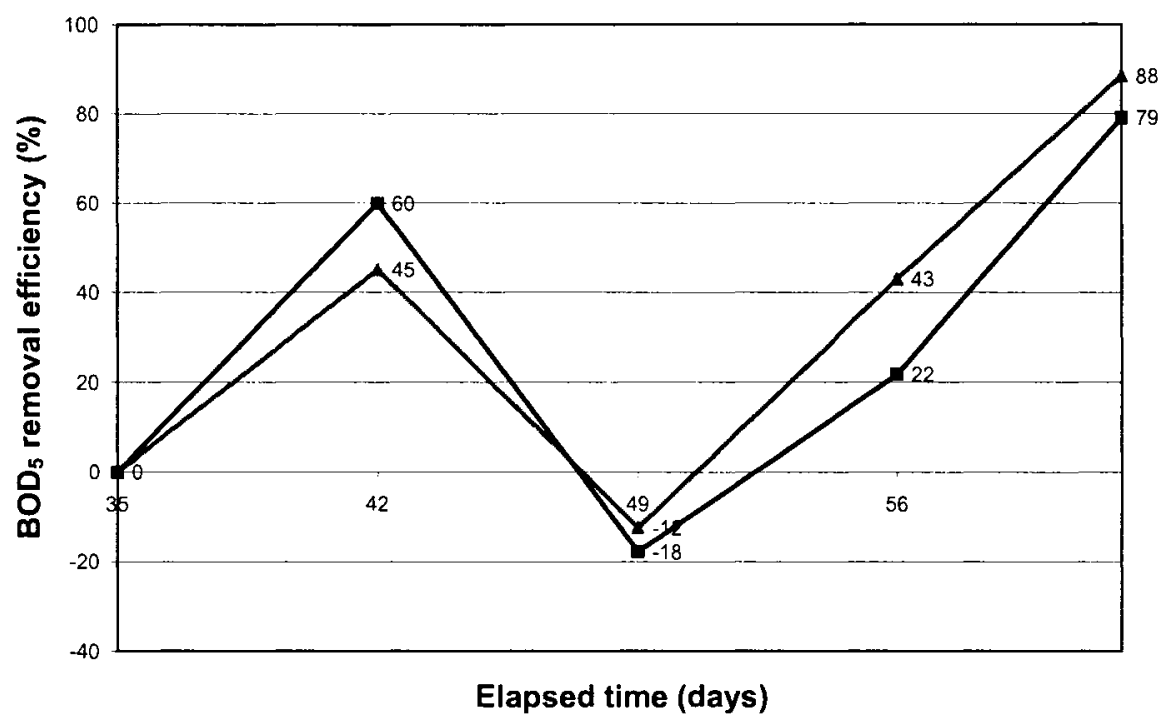

$\rightarrow$ Tire Chips $\rightarrow$-Tire Crumbs

Figure 13: Variation in $B O D_{5}$ removal efficiency in stage 3

\section{$B O D_{5}$ removal:}

The greatest $\mathrm{BOD}_{5}$ removal was achieved in this stage. The trickling filter packed with tire chips (TF1) exhibited $45 \% \mathrm{BOD}_{5}$ removal within first 7 days. Although $B O D_{5}$ increased to some extent within next 7 days, the final $B O D_{5}$ removal efficiency was $88 \%$ at the end of the stage. $A$ similar $\mathrm{BOD}_{5}$ removal pattern was noticed for the tire crumb media. Approximately $60 \% \mathrm{BOD}_{5}$ removal was achieved within the first 7 days, then there was a spike in the leachate $\mathrm{BOD}_{5}$ and the final $\mathrm{BOD}_{5}$ removal efficiency was about $79 \%$. 


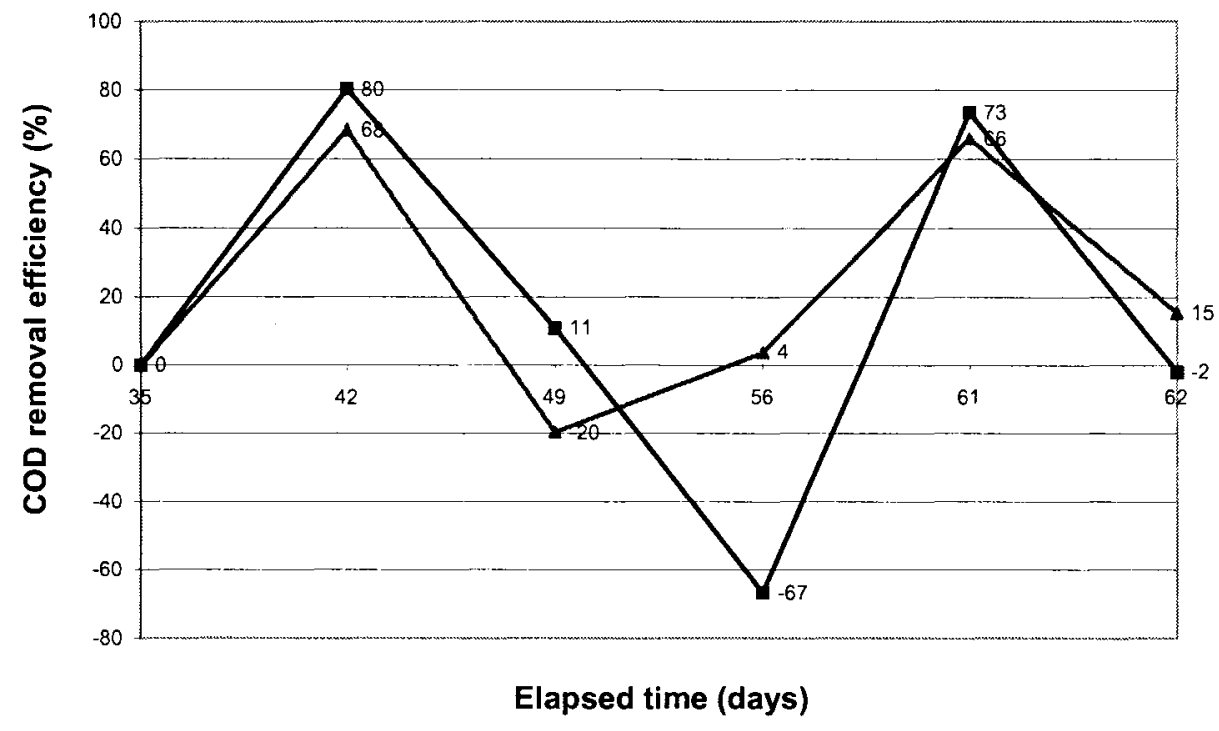

Tire Chips $\rightarrow-$ Tire Crumbs

Figure 14: Variation in COD removal efficiency in stage 3

\section{COD removal:}

Like $\mathrm{BOD}_{5}$ removal, the greatest $\mathrm{COD}$ removal was achieved in this stage. TF1 exhibited $68 \%$ COD removal within first 7 days. Thereafter the remaining COD in effluent started to increase within the next 7 days, but again triggered up to $66 \%$ finally at the end of the stage. Whereas, TF2 exhibited $80 \%$ COD removal within the first 7 days, followed by gradual increase in COD, similar to TF1. Then the COD removal efficiency increased to $73 \%$ removal on the $61^{\text {st }}$ day.

Installing a better aeration system might have increased organic removal during this stage. But a decline in the rate of organic removal because of biomass sloughing in between might have resulted in spikes in both the $B O D_{5}$ and $C O D$ in the treated effluent. 


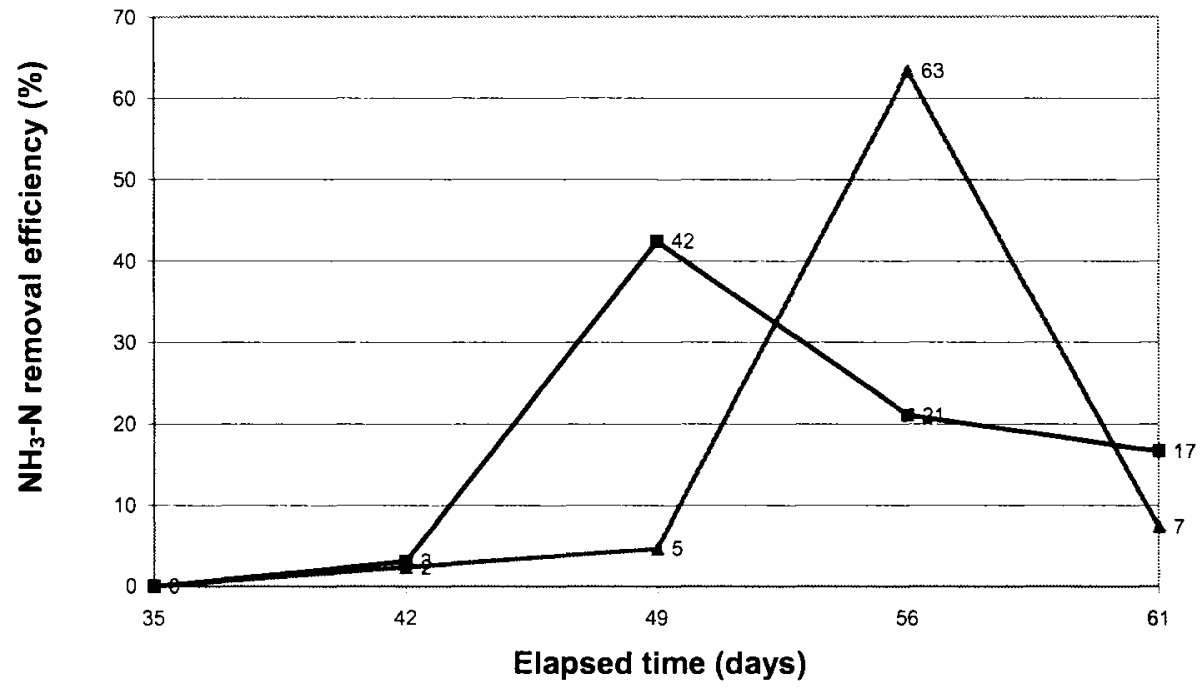

$\sim$ Tire Chips $\rightarrow-$ Tire Crumbs

Figure 15: Variation in $\mathrm{NH}_{3}-\mathrm{N}$ removal efficiency in stage 3

\section{$\mathrm{NH}_{3}-\mathrm{N}$ removal:}

Initially $\mathrm{NH}_{3}-\mathrm{N}$ removal was very slow for TF1. Then the ammonia removal started to increase after 7 days. This indicated the presence of nitrifying microorganisms in the trickling filter. After the $56^{\text {th }}$ day, the rate of ammonia removal started to decrease. This could be attributed to biomass sloughing, as explained earlier. A similar pattern of $\mathrm{NH}_{3}-\mathrm{N}$ removal was observed from TF2. Approximately $42 \% \mathrm{NH}_{3}-\mathrm{N}$ removal efficiency was observed as on $49^{\text {th }}$ day. The highest rate of ammonia removal (63\%) was achieved from TF1 during this stage. 


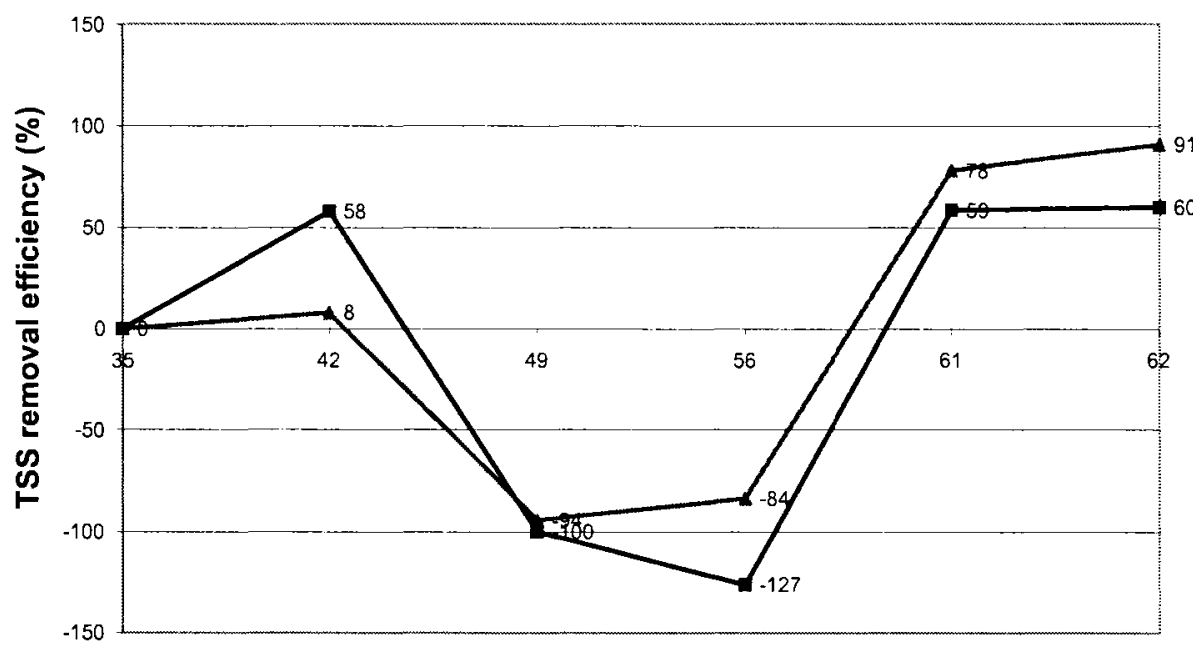

Elapsed time (days)

Tire Chips $\rightarrow$ Tire Crumbs

Figure 16: Variation in TSS removal efficiency in stage 3

\section{TSS and TS removal:}

During this stage the TSS in the effluent initially started to decrease. Approximately $8 \%$ TSS removal from TF1 and 58\% TSS removal from TF2 were achieved within a span of 7 days. However, there was a spike in TSS, from 350 $\mathrm{mg} / \mathrm{l}$ to $1250 \mathrm{mg} / \mathrm{l}$ in effluent from TF1 and 160 to $725 \mathrm{mg} / \mathrm{l}$ from TF2 within the next 14 days. As explained with regards to organic removal, this could be attributed to sloughing of biofilm attached to tire chips and crumbs. However, both filters started to exhibit better solids removal rate after the $56^{\text {th }}$ day. Approximately 98\% removal in TSS from TF1 and 59\% removal in TSS from TF2 were observed. This can be attributed to quick adsorption of suspended solids onto the tire chips and crumbs after the biomass sloughing. Also, the temperature was moderate, the $\mathrm{pH}$ was stable at 8 to 8.50 , and the effluent was enriched with sufficient dissolved oxygen. As experienced from several activated sludge processes, these are favorable conditions for solids removal. Trickling filters, being a biological system, seem to be influenced by similar conditions for solids reduction. 
Total solids (TS) removal was steady from both the filters during this stage. Approximately $73 \%$ TS removal from TF1 and TF2 were observed. In fact, TS removal increased during the last 14 days. This could be the outcome of faster organic removal, which indicates removal of dissolved solids from the leachate. When considering the unsteady TSS removal, steady TS removal from the effluent could be attributed to a steady reduction in dissolved solids.

STAGE $4\left(69^{\text {th }}\right.$ to $79^{\text {th }}$ day):

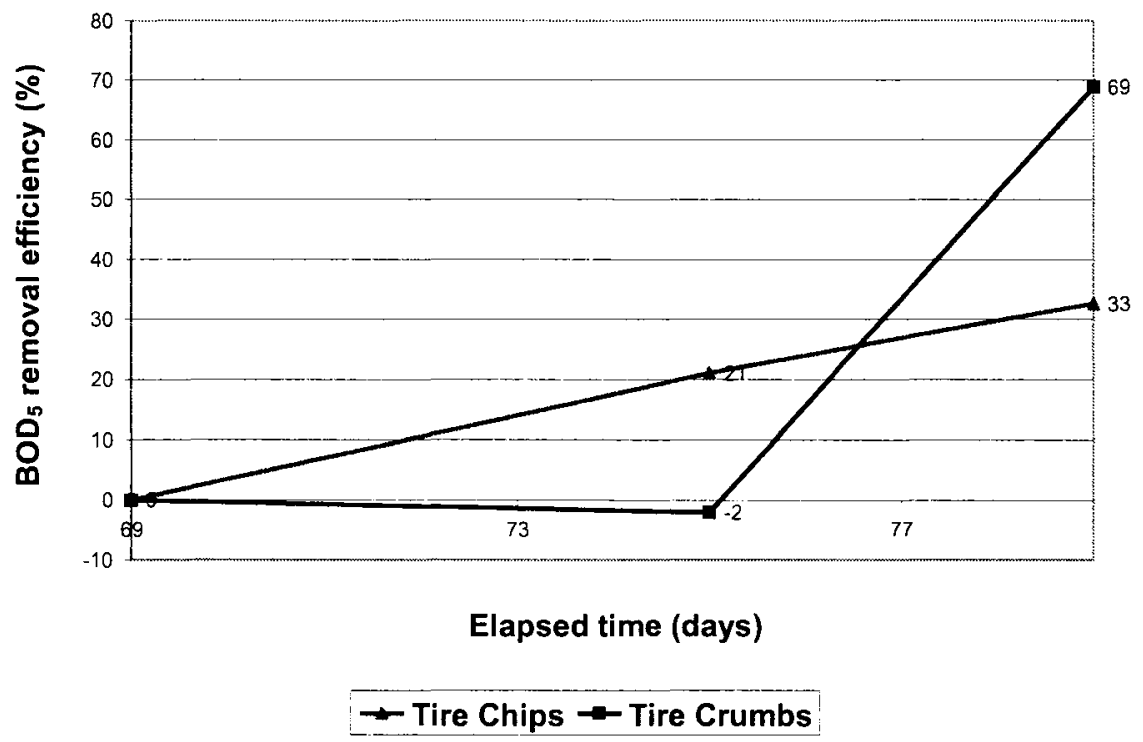

Figure 17: Variation in $\mathrm{BOD}_{5}$ removal efficiency in stage 4

\section{$\mathrm{BOD}_{5}$ removal:}

In this stage, $\mathrm{BOD}_{5}$ removal efficiency started to decrease slowly for both trickling filters. A $33 \% \mathrm{BOD}_{5}$ removal was achieved after 10 days from TF1, whereas, $\mathrm{BOD}_{5}$ removal from TF2 was much better. In TF2, $69 \% \mathrm{BOD}_{5}$ removal was achieved after 10 days. Although TF1 started to clog because of deposition of iron slag, the $\mathrm{BOD}_{5}$ removal did not decline much. 


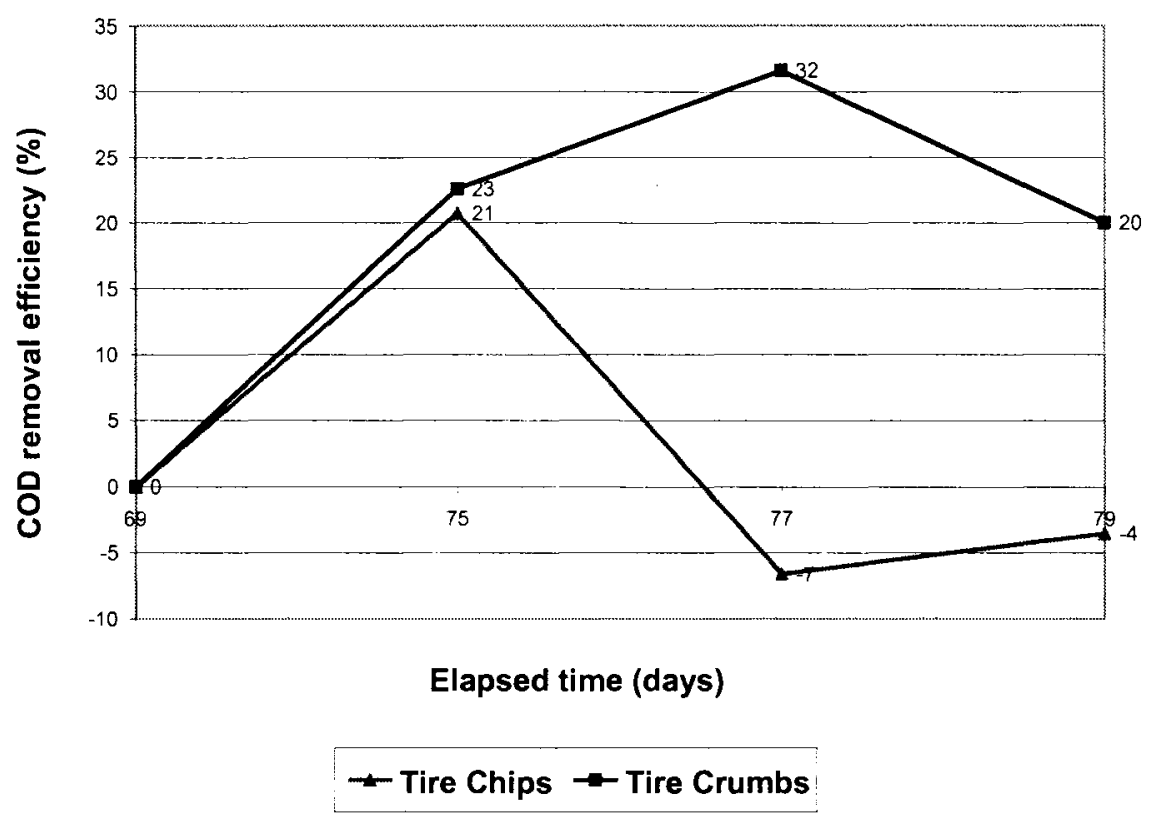

Figure 18: Variation in COD removal efficiency in stage 4

\section{COD removal:}

Like $\mathrm{BOD}_{5}$, the $\mathrm{COD}$ removal efficiency started to decrease slowly. No significant COD removal was observed from TF1 but TF2 exhibited slightly better performance, with up to $32 \%$ COD removal efficiency on the $77^{\text {th }}$ day. Therefore, it is clear in this stage that tire crumbs performed much better than the tire chips for COD removal.

In contrast to stage 3, the tire crumbs performed better than the chips. Better aeration in this stage generated sufficient dissolved oxygen and therefore the microorganisms in the tire crumbs packing media performed properly. Secondly, considering the higher surface area of tire crumbs over tire chips, it could be assumed that the biomass quantity within tire crumbs media might be higher. This might have played a major role for the better and more consistent organic removal from the tire crumbs. 


\section{$\mathrm{NH}_{3}-\mathrm{N}$ removal:}

There was no significant $\mathrm{NH}_{3}-\mathrm{N}$ removal from TF1 and TF2 in this stage.

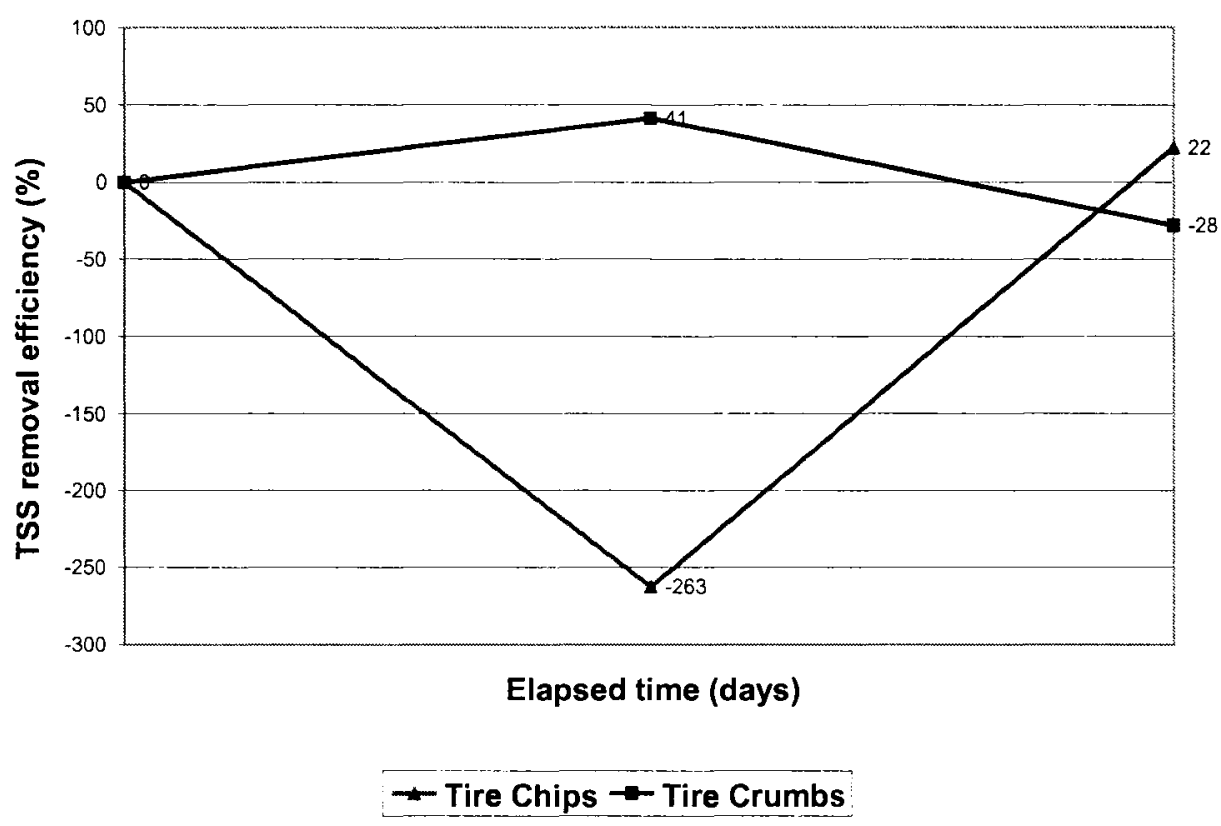

Figure 19: Variation in TSS removal efficiency in stage 4

\section{TSS and TS removal:}

TSS in the effluent from TF1 started to increase significantly up to the $77^{\text {th }}$ day. However, only $22 \%$ TSS removal was achieved in this stage from TF1. TF2 initially exhibited better performance in this sector, with $41 \%$ reduction in the first 6 days, and then TSS in treated effluent started to increase, finally ending up with virtually no suspended solids removal.

In TF1, total solids removal was very slow but steady during this stage. A $15 \%$ TS removal from TF1 was observed. 
STAGE $5\left(80^{\text {th }}\right.$ to $88^{\text {th }}$ day $)$ :

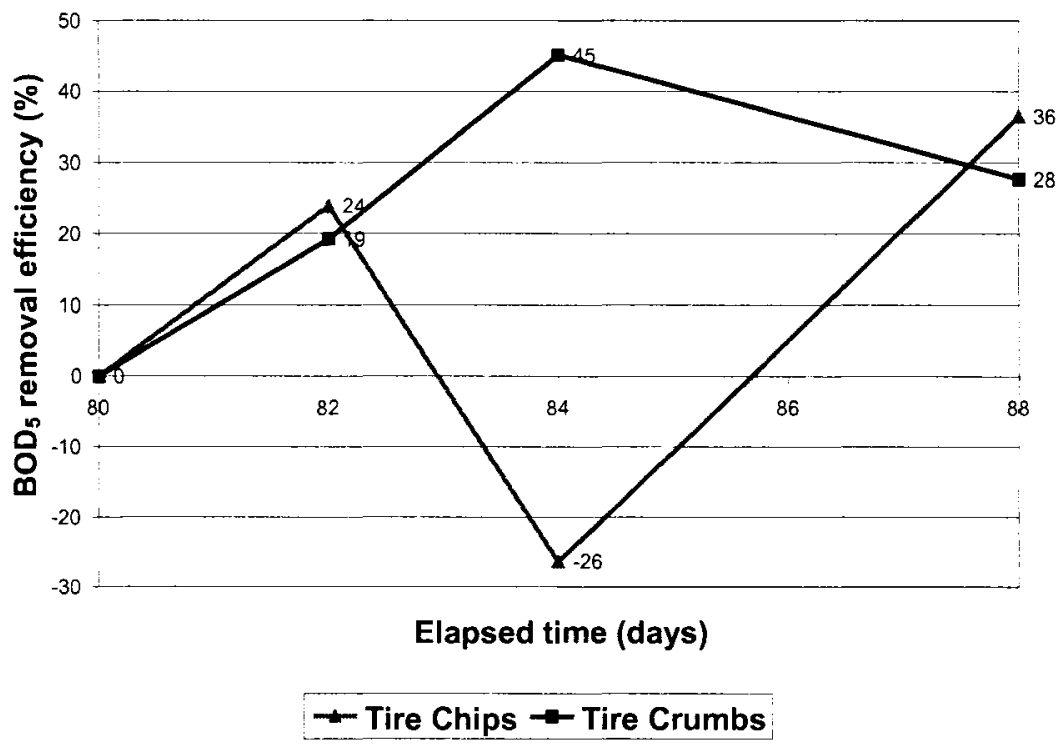

Figure 20: Variation in $\mathrm{BOD}_{5}$ removal efficiency in stage 5

\section{$\mathrm{BOD}_{5}$ removal:}

The pilot-plant exhibited clear instability with regards to $\mathrm{BOD}_{5}$ removal efficiency in this stage. A $24 \%$ removal was achieved from TF1 after just 2 days but a $26 \%$ increase in effluent $\mathrm{BOD}_{5}$ was noticed after another 2 days. This could be attributed to severe clogging in TF1. After it was backwashed, a $36 \% \mathrm{BOD}_{5}$ removal was achieved after another 4 days. A similar pattern was observed for $\mathrm{TF} 2$, where a $56 \%$ removal was achieved after 4 days of operation, and then the $\mathrm{BOD}_{5}$ removal efficiency declined to $28 \%$ in the next 4 days. Clogging in TF2 was noticed in the later half of this stage and seems, affected the organic removal efficiency. 


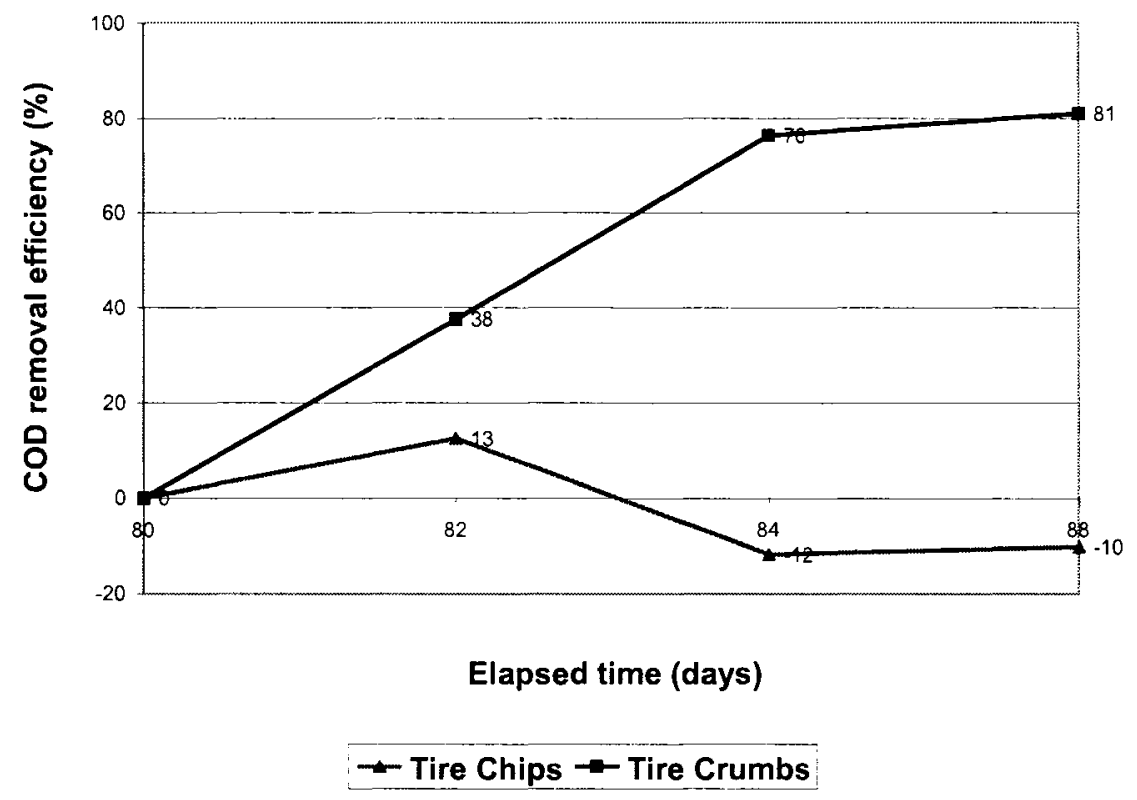

Figure 21: Variation in COD removal efficiency in stage 5

\section{COD removal:}

As explained in the case of $\mathrm{BOD}_{5}$ removal, COD removal was also poor in this stage. Nonetheless, $13 \%$ COD was removed within 2 days time from TF1. Then the COD remaining in effluent of TF1 increased. This could be attributed to severe clogging and virtually no treatment. But once the filter was backwashed, little COD removal was achieved from TF1 after another 4 days. Whereas $76 \%$ COD removal was achieved smoothly from TF2 within first 4 days, ending up with an $81 \%$ COD removal efficiency on the $88^{\text {th }}$ day. 


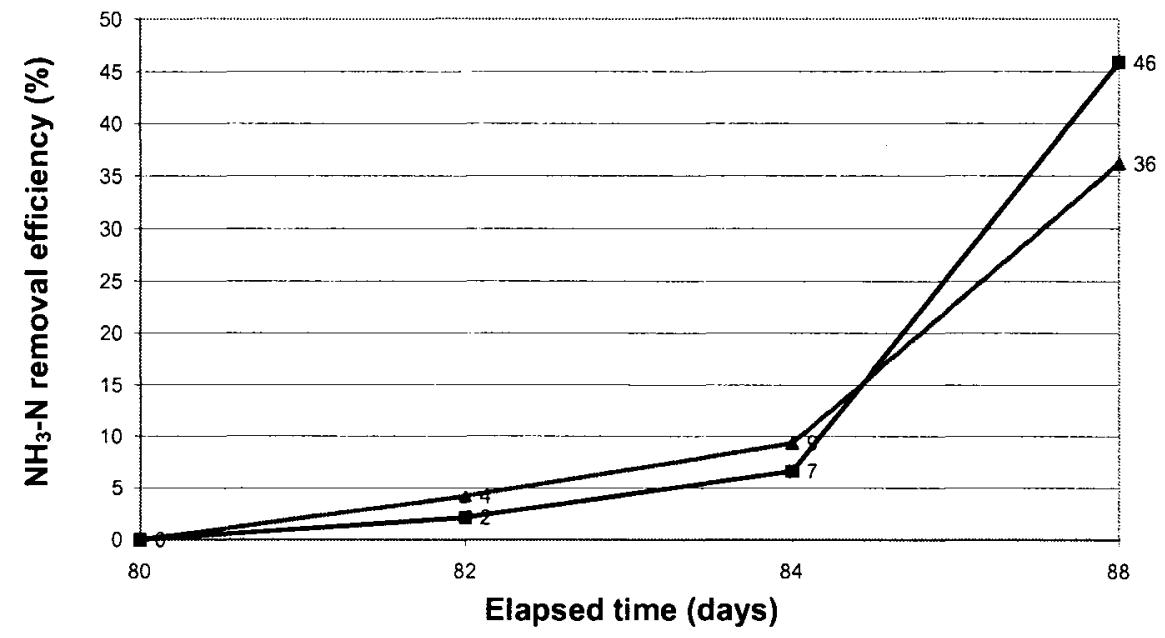

Tire Chips $\rightarrow-$ Tire Crumbs

Figure 22: Variation in $\mathrm{NH}_{3}-\mathrm{N}$ removal efficiency in stage 5

\section{$\mathrm{NH}_{3}-\mathrm{N}$ removal:}

Surprisingly $\mathrm{NH}_{3}-\mathrm{N}$ removal from TF1 was satisfactory with a $36 \%$ removal from TF1 and a $46 \%$ removal from TF2 in this stage. This could be attributed to the better performance of nitrifying bacteria after backwashing. 


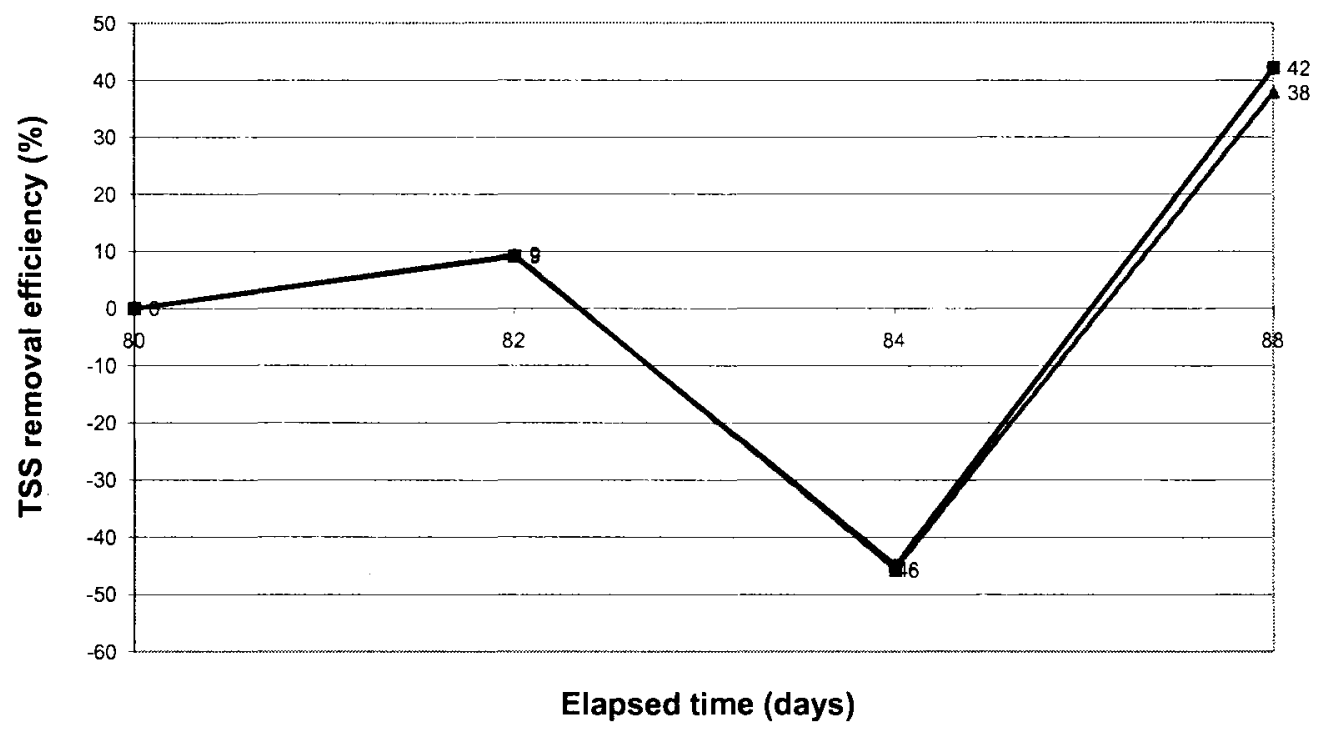

$\neq$ Tire Chips $\rightarrow$ Tire Crumbs

Figure 23: Variation in TSS removal efficiency in stage 5

\section{TSS and TS removal:}

Initially there was some TSS removal from TF1 and then the TSS increased. As TF1 was clogged, this was expected. Once the filter was backwashed, TSS in the treated effluent started to decrease. Finally, a $38 \%$ TSS removal was achieved from TF1. Similarly, TSS increased in the treated effluent from TF2. As this filter was not severely clogged, the rate of TSS increase in effluent was a little lower than that in TF1. After backwashing, 42\% TSS removal was achieved in the treated effluent at the end of this stage. Surprisingly, the pattern of effluent TSS levels was quite similar in both the filters.

A 49\% TS removal was observed from TF1 after the first 4 days, but then the TS increased to almost its initial level. TS removal from TF2 was negligible. Clogging and a reduction in organic removal might have had some impact on the total solids removal in this stage. 
STAGE $6\left(88^{\text {th }}\right.$ to $95^{\text {th }}$ day):

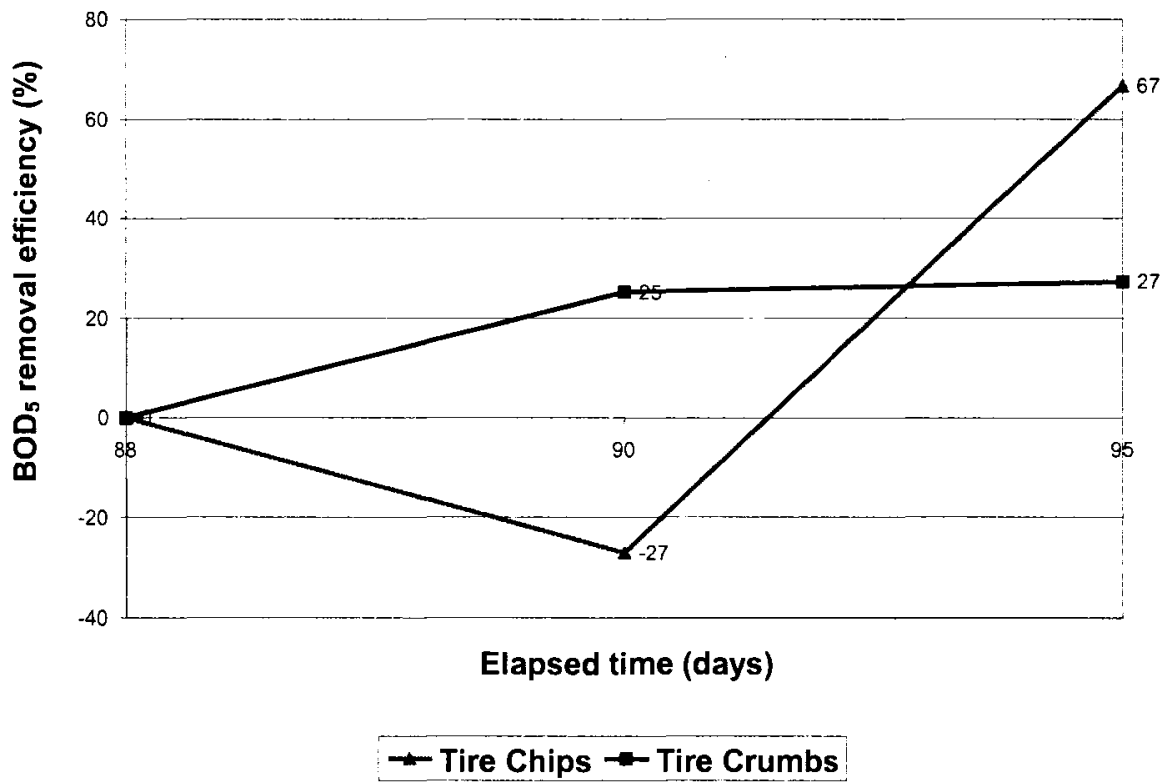

Figure 24: Variation in $\mathrm{BOD}_{5}$ removal efficiency in stage 6

\section{$\mathrm{BOD}_{5}$ removal:}

TF1 was again clogged during this stage. The $\mathrm{BOD}_{5}$ level of the effluent increased $27 \%$ from the original $\mathrm{BOD}_{5}$ in the influent. Once TF1 was backwashed, a $67 \% \mathrm{BOD}_{5}$ removal was achieved. This could be attributed to less hydraulic and organic loading into TF1 in this stage. The condition in TF2 was comparatively better. TF2 was not severely clogged during this stage. Although the rate of removal declined, $\mathrm{BOD}_{5}$ removal was steady and $27 \%$ removal was obtained after 7 days. 


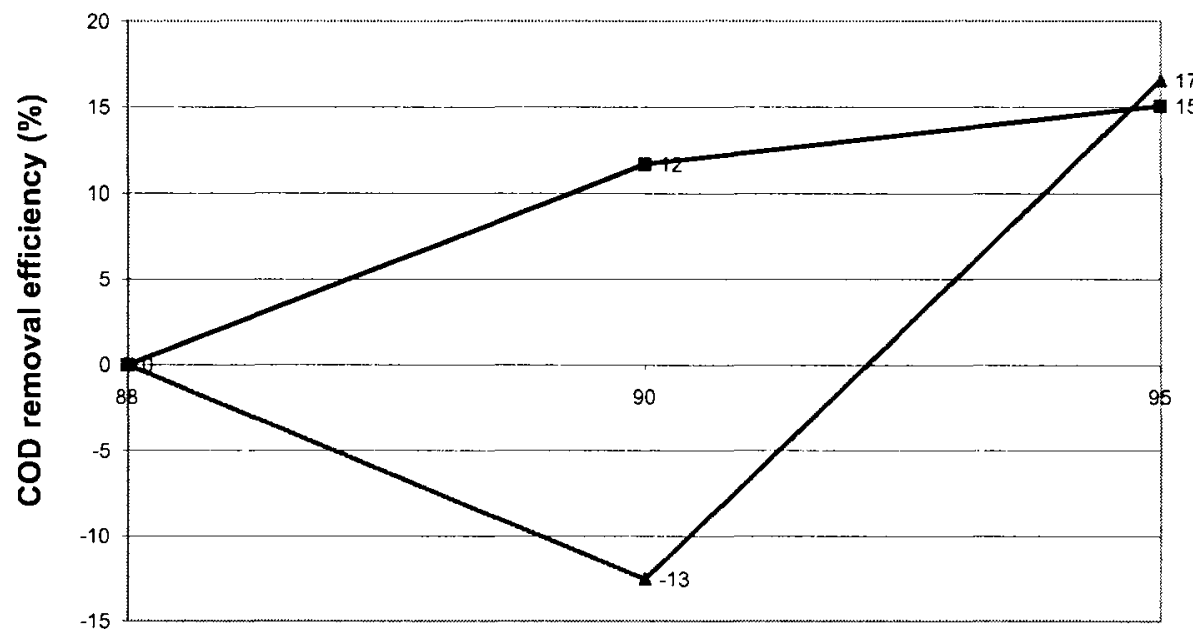

Elapsed time (days)

- Tire Chips - - Tire Crumbs

Figure 25: Variation in COD removal efficiency in Stage 6

\section{COD removal:}

Due to repeated clogging in TF1, COD removal efficiency was severely affected. Only $17 \%$ removal was obtained from TF1 in total. Whereas, TF2 exhibited a maximum $15 \%$ COD removal efficiency during this stage. However, it could be said that the COD removal efficiency was potentially affected by clogging in both the filters. 


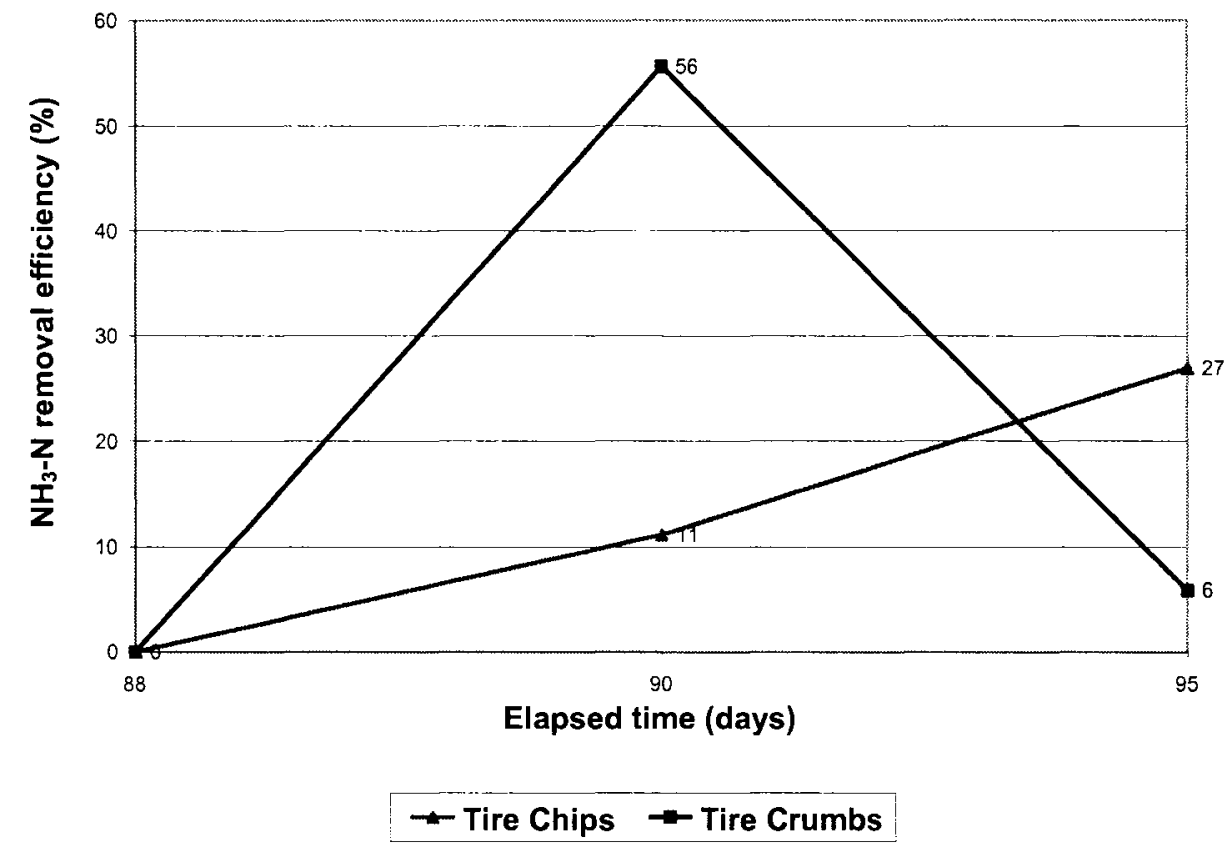

Figure 26: Variation in $\mathrm{NH}_{3}-\mathrm{N}$ removal efficiency in stage 6

\section{$\mathrm{NH}_{3}-\mathrm{N}$ removal:}

$\mathrm{NH}_{3}-\mathrm{N}$ removal from TF1 was similar to its removal efficiency in the previous stage. A maximum $27 \%$ removal was achieved from TF1 after 7 days (i.e. on the $95^{\text {th }}$ day). TF2 exhibited much better performance, with up to $56 \% \quad \mathrm{NH}_{3}-\mathrm{N}$ removal efficiency.

\section{TSS and TS removal:}

As both the filters were backwashed during the previous stage, TSS removal was improved to some extent. Almost $67 \%$ TSS removal was observed from the treated effluent from both the trickling filters.

Total solids removal was not very impressive, but steady, throughout this stage from both trickling filters. 


\subsubsection{Biomass growth and sloughing}

As understood from the above results, 21 days in stage 1 was an almost ideal solids retention time (SRT) for leachate treatment. Efficiency in organic removal in terms of $\mathrm{BOD}_{5}$ and $\mathrm{COD}$ reached at optimum level at around the 14 day period and ended up with maximum efficiency around 21 days.

Even though stage 2 was maintained for 14 days, $\mathrm{BOD}_{5}$ and $\mathrm{COD}$ removal was obtained for up to 21 days, which basically includes the first 7 days in stage 3 . This resembles earlier findings of biofilm development using tire chips. Therefore, it could be said that maximum biomass growth might have been achieved within 14 days and then started to slough after 21 days.

As the trickling filter media was not being backwashed initially, biomass sloughing might have affected organic removal efficiency. When the biofilm material sloughed off and was being discharged with the effluent, that increased $B O D_{5}$ and $C O D$ in the effluent as well as solid levels.

As pilot-plant operation was consistent with all required feedback after stage 2, an increase in $\mathrm{BOD}_{5}$ and $\mathrm{COD}$ removal rate were noticed after the first 2 weeks in stage 3. In fact, the greatest $\mathrm{BOD}_{5}$ removal ( $96 \%$ from TF1, $92 \%$ from TF2) and the greatest COD removal (90\% from both TF1 and TF2 approximately) were observed from pilot-plant during this time. This is mainly due to growth of new biofilm attached to the tire chips and crumbs. This trend continued for almost two weeks (i.e. from $49^{\text {th }}$ to $62^{\text {nd }}$ day).

Maintenance work for the pilot-plant was carried out between $63^{\text {rd }}$ to $68^{\text {th }}$ day. Then, after a gap of 6 days, while the pilot-plant operation resumed for another three stages (stages 4 to 6), a similar pattern of biofilm growth and sloughing were observed. $\mathrm{BOD}_{5}$ and $\mathrm{COD}$ removal was steady for up to 10 days in stage 4 , although organic removal rate decreased thereafter. Organic removal was achieved continuously up to another 3 days for the tire chips and 5 days for the 
tire crumbs in stage 5 . It is to be noted that even during the gap period, a portion of treated leachate was continuously recycled through both the filters to keep the microorganisms alive. Therefore, considering those six days prior to stage 4 , it can be said that a 14 vs. 21 days scenario for biofilm growth vs. sloughing has not been changed much. It is also important to mention that clogging affected leachate treatment efficiency for both the media. TF1 (packed with tire chips) clogged faster during the second half of stage 5 and particularly the last 2 days in stage 5. TF2 (packed with tire crumbs) also gradually clogged. Obviously this affected the treatment efficiency from the two filters.

\subsubsection{Mass balance analysis}

As the entire system was stable in the desired $\mathrm{pH}$ range ( 8 to 8.50 ), had sufficient dissolved oxygen and a desirable temperature during the first 15 days of stage 4 (i.e. between the $69^{\text {th }}$ and $84^{\text {th }}$ day). A mass balance, based on $B^{\circ O D_{5}}$ and COD, was attempted separately for the tire chips and the tire crumbs. $A$ second attempt, based on both the parameters, was made during stage 6 .

Major sinks considered for $\mathrm{BOD}_{5}$ and $\mathrm{COD}$ are the biofilm attached to media, treated effluent and the bottom sediment in the treated effluent tank. The sum of $B O D_{5}$ and $C O D$ in those sinks was estimated and compared to $B O D_{5}$ and $C O D$ input to TF1, TF2 separately. For easiness of calculation, it is assumed that 80 liters of leachate have been treated through the filters during the case studies. All the figures are presented in the following table. 
Table 6: Case studies on mass balance analysis based on $\mathrm{BOD}_{5}$ and COD values in influent and various sinks in trickling filter units

\begin{tabular}{|c|c|c|c|c|c|}
\hline Case & Items & $\begin{array}{r}\text { TF1 (pack } \\
\text { chi }\end{array}$ & $\begin{array}{l}\text { d with tire } \\
\text { os) }\end{array}$ & $\begin{array}{r}\text { TF2 (pack } \\
\text { cru }\end{array}$ & $\begin{array}{l}\text { d with tire } \\
\text { (bs) }\end{array}$ \\
\hline & & $\mathrm{BOD}_{5}$ (kg.) & COD (kg.) & $\mathrm{BOD}_{5}(\mathrm{~kg})$. & COD (kg.) \\
\hline & Influent & 0.320 & 0.992 & 0.326 & 0.992 \\
\hline & Sinks & & & & \\
\hline Case I & Effluent & 0.157 & 0.835 & 0.072 & 0.835 \\
\hline (during stage 4 - & Biofilm & 0.067 & 0.025 & 0.101 & 0.025 \\
\hline 5) & Sediment & 0.002 & 0.024 & 0.001 & 0.010 \\
\hline & Total & 0.226 & 0.884 & 0.174 & 0.870 \\
\hline & Influent & 0.147 & 0.863 & 0.133 & 0.863 \\
\hline & Sinks & & & & \\
\hline & Effluent & 0.062 & 0.811 & 0.072 & 0.811 \\
\hline charel & Biofilm & 0.055 & 0.002 & 0.020 & 0.003 \\
\hline & Sediment & 0.002 & 0.024 & 0.001 & 0.010 \\
\hline & Total & 0.119 & 0.837 & 0.093 & 0.824 \\
\hline
\end{tabular}

Only the determinable sinks have been considered in the above table. Therefore, it is apparent that the total quantity in the sinks cannot be equated with the input quantity. It is evident from the above result that at least one major sink is definitely missing in each and every scenario. That sink may be the loss of $\mathrm{BOD}_{5}$ and $C O D$ from the leachate because of assimilation of the leachate's organic content by microorganisms and consequent dissipation of the oxygen demand. Even if a figure is generated, subtracting total of the sinks from the input quantity; such as, in case I, $0.094 \mathrm{~kg} \mathrm{BOD}_{5}(0.320-0.226)$ or $0.108 \mathrm{~kg} \operatorname{COD}(0.992-$ 0.884 ) is there for TF1, it cannot be claimed that only microbes are responsible for the indeterminable portion of the sink, because volatile acids in the leachate 
might have been gassed-off initially and certainly this might have influenced the loss of COD at the initial stage.

So, while balancing organic removal, in addition to the treated effluent, biofilm and bottom sediment in the treated effluent tank, at least one more sink for $B O D_{5}$, being microorganisms and two more sinks for $C O D$, which are microorganisms and evaporation, have been identified. 


\section{Chapter 5: Conclusions}

\subsection{Conclusions}

Based on a performance study of tire chips and tire crumbs as trickling filter media, $\mathrm{BOD}_{5}$ removal in the range of $81-96 \%, \mathrm{COD}$ removal in the range of $76-$ $90 \%$ and $\mathrm{NH}_{3}-\mathrm{N}$ removal in the range of $15-68 \%$ was identified. More consistency in $\mathrm{BOD}_{5}, \mathrm{NH}_{3}-\mathrm{N}$ and TSS removals was achieved with the tire crumb packed trickling filter during the experimental period. A lack of consistency, in the case of the tire chip packed trickling filter could be attributed to faster clogging. Tire chips and tire crumbs both exhibited considerably better leachate treatment during stages 1 and 3 . During stage 1 , fresh chips and crumbs might have performed well due to good adsorption of the leachate's organic and inorganic components. The advantage of a developed biofilm and more stable media during stage 3 allowed both media to perform better than in stage 1 . It can be inferred that less hydraulic and organic loading might have resulted into better treatment efficiency in stage 1 and stage 3 as compared to the last three stages. This indicates that a low-rate or intermediate rate trickling filter might be a better option for leachate treatment using tire materials as the packing media.

Stage 1 was operated in a combined mode; hence any comparative assessment between the two packing media in terms of organic removal efficiency was not possible. However, overall $\mathrm{BOD}_{5}$ and $\mathrm{COD}$ removal from the pilot-plant were about $81 \%$ and $75 \%$ respectively. The $\mathrm{BOD}_{5}$ to $\mathrm{COD}$ ratio of the influent and treated effluent was 0.10 and 0.08 respectively. Whereas, stage 3 was operated in separated mode, $\mathrm{BOD}_{5}$ and $\mathrm{COD}$ ratios of the treated effluent were 0.041 and 0.096 for TF1 and TF2 respectively. The $\mathrm{BOD}_{5}$ and $\mathrm{COD}$ ratio of the influent was 0.15 for both the trickling filters in this stage. Therefore, it was determined that the organic removal efficiency of the tire chip packing media was better than that of tire crumbs. 
Organic removal efficiency in both trickling filters was reduced because of a lack of aeration during stages 2 and 3. Reinstalling a proper aeration system, just before commencement of stage 3 , might have helped tire chip and crumb packing media. Therefore, recirculation and proper aeration were determined to be two prime requirements for treating landfill leachate.

Improper aeration caused a decline in $\mathrm{BOD}_{5}, \mathrm{COD}$ removal from the pilot-plant during stage 2. It could be interpreted that the aerobic zone in the biofilm attached to the tire chips and crumbs became weak and consequently $\mathrm{BOD}_{5}$ removal was affected more. This certainly indicates that steady and proper aeration is necessary to make the biofilm's aerobic zone workable. As experienced from this experiment, proper aeration will also maintain a minimum level of dissolved oxygen and maintain $\mathrm{pH}$ in the required range.

A need for filter backwash has also been clearly identified in this experimental study. From stage 4 onwards, clogging affected the performance of both trickling filters. The tire chip packed filter was severely clogged. This was partially due to iron slags that accumulated at the bottom of the filter. This happened because of wires associated with the tire chips.

As biomass sloughing was observed after 21 days and the maximum organic and ammonia removal are also achieved at almost 21 days, it will be appropriate to backwash filters at the 21 day interval.

The tire chips and crumbs were also continuously observed for inhibitory effects regarding biofilm growth. In fact, biofilm growth was continuous and it was repeatedly observed that as long as biofilm grew over the tire materials, leachate treatment was good. Whereas, once the biofilm sloughed off, leachate treatment became poor. As this is a normal phenomenon of trickling filter operation, any major inhibitory effect and / or toxic effect of the tire chips and crumbs can be ruled out. 
Most of the solids which were removed by treatment, were ultimately found as tank bottom sediment in the treated effluent tank. This part of the solids, which is basically suspended solids, was being drained out because of biofilm sloughing after each cycle of 21 days. Treated effluent samples were collected from the top of the effluent tank after allowing solids to settle to the bottom for at least $2 \mathrm{hrs}$. This indicates that a proper settling arrangement, in addition to the trickling filtration system can improve removal of total suspended solids and total solids.

This experiment established that trickling filters packed with tire chips and crumbs can be considered as a successful biological treatment system and that can be adopted as a workable option for landfill leachate treatment.

As scrap tire is cheaper than any other usable packing media, this kind of treatment system is cost-effective and will be easily accepted by landfill operators in North America or even worldwide. Finally it is noted that tire chips and crumbs, made out of an undesirable waste like tires, have been shown to treat undesirable wastewater like landfill leachate. So, obviously this could be put to use as an alternative to many costlier options like the activated sludge process, oxidation ditch etc. Thus, critical issues pertaining to landfill leachate could be resolved by this kind of cost-effective treatment system. 


\section{Chapter 6: Recommendations}

\subsection{Recommendations}

Recommendations to improve the efficiency of a trickling filter system using the tire chips and crumbs as packing media are as follows:

- Continuous aeration into the trickling filter packed with tire material has to be arranged in order to maintain a requisite $\mathrm{pH}$ range and dissolved oxygen at least in the range of 2 to $4 \mathrm{mg} / \mathrm{l}$.

- Continuous recirculation of effluent is recommended to improve organic removal from landfill leachate.

- In the event trickling filters become clogged, immediate backwashing of the packing media is needed to improve the treatment efficiency of trickling filter. When this occurs at the end of any batch / stage, a change of packing media and increase in the gravel packing at the bottom of trickling filter could be preferred. Also a proper under-drainage system might help to minimize clogging.

- A movable distribution arm might perform better than a fixed distribution arm. In this experimental study, a fixed distribution arm was used, and there was a clear lacking in uniform biomass growth on the tire chips. Therefore, a movable distribution arm would be a better option and might perform better than a fixed distribution arm.

- Because leachate has a high organic content, organic loading into the filter has to be carefully considered. If a higher organic loading is chosen, that might create a troublesome situation for the microorganisms. They may not be able to assimilate the loading within the given time. Therefore, intermediate and / or low rate trickling filters are the possible answer for landfill leachate treatment.

Finally, depending on availability, use of almost wireless tire chips are preferred as packing media and periodic backwashing of the trickling filter is recommended to reduce clogging in the filter unit and enhance organic removal efficiency. 


\section{Chapter 7: References}

Baldwin, W.C. and Ellis, N.H. (2004). Packaged System Treats Landfill Leachate. Link - http://www.actionenv.com/art.leachate.htm.

Bouvir, J.M., Charbel, F. and Gelus, M. (1987). Gas-Solid Pyrolysis of Tire Wastes - Kinetics and Material Balances of Batch Pyrolysis of Used Tires Resources and Conservation, 15: 205-214.

Clabaugh, M.M. (2001, May). Nitrification of landfill leachate by biofilm columns. M. Eng. Thesis. Virginia Polytechnic Institute and State University, Blacksberg, Virginia. Link-http://scholar.lib.vt.edu//these/available.etd-06132001154255/unrestricted/final.pdf.

Cooke, A. J., Rowe, R. K., Fellow ASCE; Rittman, B. E., Member, ASCE; Van Gulck, J. and Millward, S. (2001, October). Biofilm Growth and Mineral Precipitation in Synthetic Leachate Columns. ASCE Journal of Geotechnical and Geoenvironmental Engineering, Vol. 127, No. 10.

CIWMB Publications, California (2003).

Link - www.ciwmb.ca.gov/LGLibrary/Innovations/Tires/PublicWorks.htm\#Civil.

CIWMB Publications, California (2003).

Link - www.ciwmb.ca.gov/Publications/Tires/43296029.doc.

Ding, A., Zhang Z., Fu J., Cheng L. (2001). Biological control of leachate from municipal landfills, Chemosphere 44, 1-8.

Dunbar landfill information (2003).

Link - www.portfolio.mvm.ed.ac.uk/studentwebs/session4/7/Leachate.htm. 
Edil T.B., M.ASCE; Park, J. K., Kim, J.Y., A.M. ASCE (2004 July). Effectiveness of Scrap Tire Chips as Sorptive Drainage Material, Journal of Environmental Engineering, $v 130, n 7, p$ 824-831.

Gonzales, L. and Williams, J. (1995). "Use of Shredded Tires as Lightweight Fill Backfill Material for Retaining Structures," Research Project Report, University of Illinois, pp. 433-451.

Grady, C.P., Daigger, G.T. and Lim, H.C. (1999). Biological Wastewater Treatment, Marcel Dekker Inc., New York.

Grimes, B. H., Ph.D.; Steve S., P.G.; and Aziz A., Ph.D. (1999). Analysis of tire chips as a substitute for stone aggregates in nitrification trenches of on-site septic systems reviewed by North Carolina's On-Site Wastewater Section. Department of Environmental Health (DEH-OSWS) and approved for publication.

Hammer J. Mark, Water and Wastewater Technology, $3^{\text {rd }}$ ed. (1996).

Humphrey, D. N. (1999 March 3-5). "Civil Engineering Applications of Tire Shreds," Proceedings of the Tire Industry Conference, Clemson University, 16: pp. 425-436.

losif, K., Reali, A., Reali M., Reznik, I.B., NY, USA (1997). Tire Recycling Process, Journal of Cleaner Production, Vol.5, No.4, pp: 316-317.

John, N., Joseph, R. (1999 February). Use of copoly (styrene/butadiene/vinyl pyridine) latex based adhesives for bonding wood, Plastic, Rubber and Composites, vol. 28 , no. 2 , pp. 80-83(4). 
Kargi, F., Pamukoglu, M. Y. (2003). Simultaneous adsorption and biological treatment of pre-treated landfill leachate by fed-batch operation, Process Biochemistry 38, 1413-1420, 14.

Khanbilverdi, R.M., Ahmed S., Gleason P.J. (1995 January). Flow investigation for Landfill leachate (Fill), ASCE Journal of Environmental Engineering, Vol. 121, No. 1.

Kim, J. Y., Park, J. K., and Edil, T.B. (1997b). "Sorption of organic compounds in the aqueous phase onto tire rubber," J. Environ Eng., 123(9), 827-835.

Knox, K. (1985). Leachate treatment with nitrification of ammonia, Water Research Vol. 19, No. 7, pp $895-904$.

Knox K. (1983). Treatability Studies on Leachate from a Co-disposal Landfill, Environmental Pollution (Series B) 5, 157-174.

Lee, J. H., Salgado, R., Bernal, A., Member, ASCE; and Lovell, C. W., Fellow ASCE (1999 February). Shredded Tires and Rubber-Sand as Lightweight Backfill. ASCE Journal of Geotechnical and Geo-environmental Engineering, Vol. 125 , No.2.

Lo, Irene M.-C. (1996). Characteristics and treatment of leachates from domestic landfills, Environment International, Volume: 22, Issue: 4, pp. 433-442.

Maliokas V. (1999 October). The In Situ Purification Method For The Treatment Of Leachate From A Landfill Proceedings Sardinia 99, Seventh International Waste Management and Landfill Symposium S. Margherita di Pula, Cagliari, Italy; 4-8. 
Metcalf and Eddy, Wastewater Engineering, treatment and reuse. $4^{\text {th }}$ ed. (2002).

Mott, H.V., Hartz, K.E., Yonge, D.R. (1987). Landfill leachates. J. Environ. Eng. $113(3), 476-485$.

USEPA (2003). Municipal solid waste generations, recycling and disposal in the United States: Facts and figures.

National Environmental Services Center Publication, West Virginia University, (2004). Link -www.nesc.wvu.edu/nsfc/pdf/pipline/PL_w04.pdf.

Paris, H. C. (1996). Assessment of leachate from sanitary landfills: impact of age, rainfall, and treatment; Environment International, Volume: 22, Issue; 2, pp. 225237.

Parker D.S., Bratby J. R. (2001 May). Review of two decades of experience with TF/SC process, Journal of Environmental Engineering, Vol. 127, No. 5.

Richter A. Y. and Weaver R.W. (2003 December). Treatment of domestic wastewater by subsurface flow constructed wetlands filled with gravel and tire chip media. Environmental Technology, vol.24, no. 12 pp 1561-1567.

Rodriguez J., Castrillon L., Maranon E., Sastre H., Fernandez E. (2004). Removal of non-biodegradable organic matter from landfill leachates by adsorption. Water Research, 38, 3297-3303.

Rowe, R. K., Vangulck, J. F., Milward, S. C. (2002). Biologically induced clogging of a granular medium permeated with synthetic leachate J. Environ. Eng. Sci. 1: 135-156. 
Slack, R.J., Gronow, J.R., Voulvoulis, N. (2005). Household hazardous waste in municipal landfills: contaminants in leachate, Science of the Total Environment 337, pp: 119-137.

Shin Hang-Sik., Yoo Kyu-Seon, Park, J. K. (1999 May-June). Removal of polychlorinated phenols in sequential anaerobic-aerobic biofilm reactors packed with tire chips. Water Environment Research, Alexandria. Vol. 71, Iss. 3; p. 363367.

Sompote, Y., Dennes T.B. (2003 April); Strength and deformation characteristics of shredded rubber tire - sand mixtures. Canadian Geotechnical Journal, 40, 2; Wilson Applied Science \& Technology Abstracts pg. 254.

Tatsi, A.A., Zouboulis, A. I., Matis, K.A., Samaras, P. (2003). Coagulationflocculation pretreatment of sanitary landfill leachates Chemosphere 53, 737-744.

Toutanji, H.A. (1996). The Use of Rubber Tire Particles in Concrete to replace Mineral Aggregates Cement \& Concrete Composites, 18, 135-139.

University of Maine Report (2004). Linkhttp://useit.umeciv.maine.edu/materials/tires/eprop/engineering_properties.htm.

University of Manitoba Design Report (2005). Link www.ce.umanitoba.ca/ ugrad/ftp/23.370\%20Enviro\%20Eng\%20Design/Attached _growth(1)-rev2.ppt.

Warith, M. A., Evgin, E., Benson, P.A.S. (2004). Suitability of tire chips in landfill leachate collection system. Waste Management (24), pp 967 - 979. 
Warith, M.A., Evgin, E., Benson, P.A.S. and Rao S.M. (2005 January). Evaluation of Permeability of Tire Shreds Under Vertical Loading, Journal of Testing and Evaluation, vol. 33, No. 1.

Warith, M.A., Abdel, Aziz, G., and Braz, W.S. (2002 October 6-9). "Characteristics of Shredded Tires as Landfill Filter Media, "Proceedings Second International Conference on Geo-technical and Geo-environmental Engineering in Arid Lands, Riyadh, Saudi Arabia, pp. 367-373.

Wang, Z.P., Zhang, Z., Lin, Y.J., Deng, N.S., Tao, T., Zhou, K. (2002). Landfill leachate treatment by a coagulation-photooxidation process, J. Hazardous Mater, 95 (1/2), 153-159.

Waterloo biofilter Systems Inc. (2004). Link -

http://strategis.ic.gc.ca/app/ccc/search/navigate.do?language=eng\&portal=1\&est blmntNo=234567017731\&profile=completeProfile.

Winkler, M.A. (1981). "Biological Treatment of Wastewater". Ellis Horwood Limited, Chichester, England, p. 15, pp. 164-210.

Yang Zhan (2002). Biological Wastewater Treatment: Pilot Plant Studies Using a Trickling Filter; B. Eng. Thesis, Chemical Engineering Program, Department of Chemistry, Biology and Chemical Engineering, Ryerson Polytechnic University, Toronto.

Yang, S., Lohnes, R. A., and Kjartanson B.H. (2002 March). Mechanical Properties of Shredded Tires Geotechnical Testing Journal, GTJODJ, Vol. 25, No. 1 , pp. 44-52. 


\section{Appendix-1}

\section{Sample Calculation}

\section{Sample calculation for removal efficiency determination}

Stage 1:

For TF1 (tire chips packed)

$\mathrm{BOD}_{5}$ of influent at 0 day $=1002 \mathrm{mg} / \mathrm{l}$ (at the start of batch)

$\mathrm{BOD}_{5}$ of effluent at $7^{\text {th }}$ day $=646 \mathrm{mg} / \mathrm{l}$

Hence, $\mathrm{BOD}_{5}$ removal efficiency as measured on $7^{\text {th }}$ day

$=((1002-646) / 1002) * 100=35.53 \%$

$\mathrm{BOD}_{5}$ of influent at $7^{\text {th }}$ day $=646 \mathrm{mg} / \mathrm{l}$

$B O D_{5}$ of effluent at $14^{\text {th }}$ day $=257 \mathrm{mg} / \mathrm{l}$

Hence, $\mathrm{BOD}_{5}$ removal efficiency as measured on $14^{\text {th }}$ day

$=((646-257) / 646) * 100=60.22 \%$

$B O D_{5}$ of influent at $14^{\text {th }}$ day $=257 \mathrm{mg} / \mathrm{l}$

$\mathrm{BOD}_{5}$ of effluent at $21^{\text {st }}$ day $=192 \mathrm{mg} / \mathrm{l}$

Hence, $\mathrm{BOD}_{5}$ removal efficiency as measured on $21^{\text {st }}$ day

$=((257-192) / 257) * 100=25.30 \%$

Note: All other removal efficiencies pertaining to $\mathrm{BOD}_{5}, \mathrm{COD}, \mathrm{NH}_{3}-\mathrm{N}, \mathrm{TSS}$ and

TS from time to time for all the stages were calculated as per above procedure. 


\section{Appendix-2}

Table 7: Major components of the trickling filter pilot-plant

\begin{tabular}{|c|c|c|c|}
\hline No. & Name & Quantity & Description \\
\hline 1 & $\begin{array}{l}\text { Fixed distributor with } \\
\text { distributor arm }\end{array}$ & 2 & $\begin{array}{l}\text { For two filtration units, fabricated from PVC } \\
\text { pipe material, holes are made manually. }\end{array}$ \\
\hline 2 & Filter - tower & 2 & $\begin{array}{l}\text { PVC tank of } 0.6 \mathrm{~m} \text { diameter and } 1.26 \mathrm{~m} \text { high, } \\
\text { used as two filtration units }\end{array}$ \\
\hline 3 & $\begin{array}{l}\text { Filter- dome or PVC- } \\
\text { cover }\end{array}$ & 2 & $\begin{array}{l}\text { Filter-dome is not necessary for laboratory } \\
\text { scale trickling filter. But PVC cover was } \\
\text { provided at the top of the filter-tower. }\end{array}$ \\
\hline 4 & $\begin{array}{l}\text { Influent leachate } \\
\text { tank }\end{array}$ & 1 & PVC tank (625 liter cap.) with cover. \\
\hline 5 & Treated effluent tank & 2 & $\begin{array}{l}\text { For treated leachate collection, standard } \\
\text { plastic bins (100 liter cap.) with cover were } \\
\text { used }\end{array}$ \\
\hline 6 & Air Compressor & 1 & As available in the laboratory \\
\hline 7 & $\begin{array}{l}\text { Ventilation fan with } \\
\text { timer arrangement }\end{array}$ & 1 & $\begin{array}{l}\text { This was used in place of air compressor, } \\
\text { while it broke down }\end{array}$ \\
\hline 8 & $\begin{array}{l}\text { Leachate pump } \\
\text { (Influent pump) }\end{array}$ & 1 & $\begin{array}{l}\text { Water lifting pump, Cap. } 0.1 \mathrm{gpm} \text {, head } 5 \mathrm{~m} \text {, } \\
0.25 \mathrm{HP}\end{array}$ \\
\hline 9 & Rotameter & 1 & $\begin{array}{l}\text { This is flow meter fitted with common pump } \\
\text { supply header in order to monitor flow. }\end{array}$ \\
\hline 10 & Ball valve & 8 & $\begin{array}{l}1 / 4 \text { inch size gate valve, ( } 1 \text { no. for influent, } 2 \\
\text { nos. for influent branches, } 1 \text { no. for bypass } \\
\text { arrangement, } 2 \text { nos. for air supply line), } 1 \text { inch } \\
\text { size gate valve ( } 2 \text { nos. for effluent line) }\end{array}$ \\
\hline 11 & $\begin{array}{l}\text { Pipes and } \\
\text { accessories }\end{array}$ & 1 lot & $\begin{array}{l}1 / 2 \text { inch dia. PVC pipe and accessories like } \\
\text { bend, union, tee etc. }\end{array}$ \\
\hline 12 & $\begin{array}{l}\text { Sludge / waste } \\
\text { scrapper }\end{array}$ & 1 & As and when necessary \\
\hline
\end{tabular}


Table 8: Methods and instruments used for laboratory analysis

\begin{tabular}{|c|c|c|c|}
\hline SI. & Test performed & Method & Major instruments used \\
\hline 1 & 5-day BOD & $\begin{array}{l}\text { Section } 5210 \text { B. 5-DAY } \\
\text { BOD test, Standard } \\
\text { Method, } 1998\end{array}$ & $\begin{array}{l}\text { Isotemp Incubator, make: Fisher } \\
\text { Scientific, Canada. } \\
\text { Orion } 3 \text { Star DO Benchtop, make: } \\
\text { Thermo Electron Corporation, USA }\end{array}$ \\
\hline 2 & COD & $\begin{array}{l}\text { High-range Micro-COD test } \\
\text { method (Bioscience Inc.) in } \\
\text { accordance with section } \\
5220 \text { D. Closed Reflux, } \\
\text { Colorimetric Method, } \\
\text { Standard Method, } 1998\end{array}$ & $\begin{array}{l}\text { COD reactor, make: Bioscience } \\
\text { Inc., USA. } \\
\text { Lambda } 20 \text { Spectrophotometer } \\
\text { (available in Ryerson University } \\
\text { Analytical Centre, Ryerson } \\
\text { University, Toronto). }\end{array}$ \\
\hline 3 & $\mathrm{NH}_{3}-\mathrm{N}$ & $\begin{array}{l}\text { 4500- } \mathrm{NH}_{3} \mathrm{~F} . \text { Phenate } \\
\text { Method, Standard Method, } \\
1998\end{array}$ & $\begin{array}{l}\text { Lambda } 20 \text { Spectrophotometer } \\
\text { (Available in Ryerson University } \\
\text { Analytical Centre, Ryerson } \\
\text { University, and Toronto). }\end{array}$ \\
\hline 4 & TSS & $\begin{array}{l}2540 \text { D. Total Suspended } \\
\text { Solids Dried at } 103-105^{\circ} \mathrm{C} \text {, } \\
\text { Standards Method, } 1998\end{array}$ & $\begin{array}{l}\text { Isotemp Oven (Model 630G), } \\
\text { make: Fisher Scientific, Canada. }\end{array}$ \\
\hline 5 & TS & $\begin{array}{l}2540 \mathrm{~B} \text {. Total Solids Dried } \\
\text { at } 103-105^{\circ} \mathrm{C} \text {, Standards } \\
\text { Method, } 1998\end{array}$ & $\begin{array}{l}\text { Isotemp Oven (Model 630G), } \\
\text { make: Fisher Scientific, Canada. }\end{array}$ \\
\hline 6 & $\mathrm{pH}$ & - & $\begin{array}{l}\text { Accumet Basic pH meter, make: } \\
\text { Fisher Scientific, Canada. }\end{array}$ \\
\hline 7 & Temperature & - & $\begin{array}{l}\text { Temperature meter, make: VWR, } \\
\text { Canada }\end{array}$ \\
\hline 8 & DO & - & $\begin{array}{l}\text { Orion } 3 \text { Star DO Benchtop, make: } \\
\text { Thermo Electron Corporation, } \\
\text { USA. }\end{array}$ \\
\hline 9 & $\begin{array}{l}\text { Biomass thickness } \\
\text { measurement }\end{array}$ & - & $\begin{array}{l}\text { Electronic Digital Caliper, make: } \\
\text { KAR, USA }\end{array}$ \\
\hline
\end{tabular}




\section{Appendix-3}

Table 9: pH and temperature of trickling filter units

\begin{tabular}{|c|c|c|c|c|}
\hline \multirow{2}{*}{ Days } & \multicolumn{2}{|c|}{ TF1 (Tire Chips) } & \multicolumn{2}{|c|}{ TF2 (Tire Crumbs) } \\
\hline & $\mathbf{p H}$ & Temp. $\left({ }^{\circ} \mathrm{C}\right)$ & $\mathrm{pH}$ & Temp. $\left({ }^{\circ} \mathrm{C}\right)$ \\
\hline 1 & 8.79 & 20.5 & 8.79 & 20.5 \\
\hline 3 & 8.80 & 20.8 & 8.79 & 20.9 \\
\hline 4 & 8.78 & 21.0 & 8.78 & 21.0 \\
\hline 5 & 8.76 & 19.0 & 8.76 & 19.0 \\
\hline 7 & 8.75 & 20.0 & 8.74 & 20.0 \\
\hline 8 & 8.73 & 20.0 & 8.73 & 21.0 \\
\hline 10 & 8.60 & 19.0 & 8.70 & 19.0 \\
\hline 11 & 8.52 & 18.0 & 8.62 & 19.0 \\
\hline 15 & 8.52 & 19.0 & 8.62 & 19.0 \\
\hline 16 & 8.47 & 20.0 & 8.57 & 20.0 \\
\hline 18 & 8.45 & 20.0 & 8.56 & 20.0 \\
\hline 21 & 8.48 & 18.0 & 8.48 & 19.0 \\
\hline 22 & 8.48 & 16.0 & 8.48 & 16.0 \\
\hline 23 & 8.52 & 18.0 & 8.48 & 20.0 \\
\hline 27 & 8.62 & 19.0 & 8.48 & 20.0 \\
\hline 29 & 8.63 & 18.5 & 8.52 & 19.0 \\
\hline 30 & 8.58 & 19.0 & 8.62 & 19.0 \\
\hline 35 & 8.54 & 18.7 & 8.63 & 20.0 \\
\hline 35 & 6.97 & 19.0 & 6.87 & 22.0 \\
\hline 36 & 7.57 & 19.0 & 7.47 & 19.0 \\
\hline 37 & 8.19 & 20.0 & 7.81 & 20.0 \\
\hline 38 & 8.16 & 20.0 & 7.91 & 20.0 \\
\hline 39 & 8.15 & 20.0 & 8.05 & 20.0 \\
\hline 41 & 8.11 & 20.0 & 8.03 & 20.0 \\
\hline 43 & 7.95 & 17.0 & 8.08 & 17.0 \\
\hline 44 & 7.93 & 17.0 & 8.06 & 17.0 \\
\hline 45 & 7.92 & 16.0 & 8.05 & 17.0 \\
\hline 46 & 8.73 & 20.0 & 8.15 & 20.0 \\
\hline 47 & 8.65 & 19.0 & 8.36 & 19.0 \\
\hline 48 & 8.60 & 19.0 & 8.55 & 19.0 \\
\hline 49 & 8.52 & 18.0 & 8.73 & 21.0 \\
\hline 50 & 7.96 & 18.0 & 8.11 & 18.0 \\
\hline 51 & 8.07 & 19.0 & 7.93 & 19.0 \\
\hline 52 & 8.11 & 19.0 & 7.99 & 19.0 \\
\hline 53 & 8.13 & 16.0 & 8.05 & 16.0 \\
\hline 54 & 8.47 & 17.0 & 8.08 & 17.0 \\
\hline 55 & 8.34 & 17.0 & 8.12 & 17.0 \\
\hline 56 & 8.24 & 18.0 & 8.08 & 18.0 \\
\hline 57 & 8.32 & 19.0 & 8.05 & 19.0 \\
\hline 58 & 8.36 & 18.0 & 8.56 & 20.0 \\
\hline 59 & 8.30 & 15.0 & 8.48 & 21.0 \\
\hline 60 & 8.48 & 16.0 & 8.32 & 20.0 \\
\hline
\end{tabular}




\begin{tabular}{|c|c|c|c|c|}
\hline \multirow{2}{*}{ Days } & \multicolumn{2}{|c|}{ TF1 (Tire Chips) } & \multicolumn{2}{c|}{ TF2 (Tire Crumbs) } \\
\cline { 2 - 5 } & $\mathbf{p H}$ & Temp. ${ }^{\circ} \mathbf{C}$ ) & $\mathbf{p H}$ & Temp. $^{\circ} \mathbf{C}$ ) \\
\hline 61 & 8.14 & 18.0 & 8.00 & 17.0 \\
\hline 62 & 8.10 & 19.0 & 8.24 & 16.0 \\
\hline 63 & 8.15 & 19.0 & 8.30 & 16.0 \\
\hline 64 & 8.20 & 18.0 & 8.26 & 17.0 \\
\hline 65 & 8.30 & 18.0 & 8.20 & 18.0 \\
\hline 66 & 8.25 & 17.0 & 8.11 & 17.0 \\
\hline 67 & 8.18 & 17.0 & 8.08 & 17.0 \\
\hline 68 & 8.20 & 16.0 & 8.50 & 21.0 \\
\hline 69 & 7.50 & 20.0 & 8.10 & 19.4 \\
\hline 70 & 7.90 & 20.0 & 8.50 & 19.9 \\
\hline 71 & 8.00 & 20.0 & 8.34 & 20.0 \\
\hline 72 & 8.05 & 21.9 & 8.56 & 21.6 \\
\hline 73 & 8.10 & 16.4 & 8.25 & 16.3 \\
\hline 74 & 8.11 & 16.6 & 8.28 & 16.4 \\
\hline 75 & 9.27 & 22.0 & 8.38 & 22.4 \\
\hline 76 & 9.00 & 21.0 & 8.49 & 21.9 \\
\hline 77 & 8.40 & 17.9 & 8.52 & 18.0 \\
\hline 78 & 8.42 & 18.1 & 8.54 & 18.3 \\
\hline 79 & 9.01 & 20.1 & 8.76 & 20.4 \\
\hline 80 & 8.99 & 18.2 & 8.50 & 22.2 \\
\hline 82 & 8.55 & 17.4 & 8.15 & 17.3 \\
\hline 84 & 8.68 & 17.8 & 8.32 & 17.5 \\
\hline 86 & 8.40 & 18.2 & 8.20 & 18.3 \\
\hline 88 & 8.74 & 19.5 & 8.51 & 19.3 \\
\hline 88 & 7.54 & 20.1 & 7.90 & 20.5 \\
\hline 89 & 7.68 & 19.5 & 8.00 & 19.3 \\
\hline 90 & 8.01 & 20.3 & 8.19 & 20.1 \\
\hline 91 & 8.08 & 19.6 & 8.26 & 20.5 \\
\hline 93 & 8.27 & 19.7 & 8.24 & 19.6 \\
\hline 94 & 8.19 & 19.9 & 8.23 & 19.9 \\
\hline 95 & 8.30 & 19.4 & 8.23 & 18.3 \\
\hline & & & & \\
\hline
\end{tabular}


Table 10: Stage-wise total suspended solids and total solids analysis

\begin{tabular}{|c|c|c|c|c|c|}
\hline \multirow{3}{*}{ Stage } & \multirow{2}{*}{ Days } & \multicolumn{2}{|c|}{ TF1 (Tire Chips) } & \multicolumn{2}{c|}{ TF2 (Tire Crumbs) } \\
\cline { 2 - 6 } & & TSS (mg/l) & TS (mg/l) & TSS (mg/l) & TS (mg/l) \\
\hline \multirow{4}{*}{ Stage 1 } & 0 & 900 & 14556 & 900 & 14556 \\
\cline { 2 - 6 } & 5 & 600 & 10917 & 600 & 10917 \\
\cline { 2 - 6 } & 10 & 700 & 7700 & 700 & 7700 \\
\cline { 2 - 6 } & 14 & 750 & 5250 & 750 & 5250 \\
\cline { 2 - 6 } & 21 & 467 & 4940 & 467 & 4940 \\
\hline \multirow{3}{*}{ Stage 2 } & 21 & 503 & 9280 & 503 & 9280 \\
\cline { 2 - 6 } & 28 & 225 & 6325 & 300 & 6575 \\
\cline { 2 - 6 } & 35 & 150 & 5725 & 120 & 6175 \\
\hline \multirow{5}{*}{ Stage 3 } & 35 & 380 & 18675 & 380 & 18675 \\
\cline { 2 - 6 } & 42 & 350 & 12390 & 160 & 11850 \\
\cline { 2 - 6 } & 49 & 680 & 16120 & 320 & 17540 \\
\cline { 2 - 6 } & 56 & 1250 & 12700 & 725 & 13533 \\
\cline { 2 - 6 } & 61 & 275 & 5333 & 300 & 5000 \\
\hline \multirow{3}{*}{ Stage 4 } & 62 & 25 & 5067 & 120 & 18525 \\
\cline { 2 - 6 } & 69 & 700 & 27033 & 640 & 21475 \\
\cline { 2 - 6 } & 77 & 2540 & 23900 & 375 & 18833 \\
\hline \multirow{3}{*}{ Stage 5 } & 79 & 1975 & 23033 & 480 & 27080 \\
\cline { 2 - 6 } & 80 & 682 & 37750 & 550 & 18000 \\
\cline { 2 - 6 } & 82 & 618 & 22725 & 500 & 22575 \\
\cline { 2 - 6 } & 84 & 900 & 19367 & 725 & 20300 \\
\hline \multirow{3}{*}{ Stage 6 } & 88 & 2040 & 20500 & 2040 & 19267 \\
\cline { 2 - 6 } & 90 & 1200 & 21000 & 1820 & 18833 \\
\cline { 2 - 6 } & 95 & 680 & 19200 & 680 & 17900 \\
\hline
\end{tabular}


Table 11: Stage-wise $B O D_{5}, C O D$ and $\mathrm{NH}_{3}-\mathrm{N}$ analysis

\begin{tabular}{|c|c|c|c|c|c|c|c|}
\hline \multirow[b]{2}{*}{ Stage } & \multirow[b]{2}{*}{ Days } & \multicolumn{3}{|c|}{ TF1 (Tire Chips) } & \multicolumn{3}{|c|}{ TF2 (Tire Crumbs) } \\
\hline & & $\begin{array}{l}\mathrm{BOD}_{5} \\
(\mathrm{mg} / \mathrm{l})\end{array}$ & $\begin{array}{l}\text { COD } \\
(\mathrm{mg} / \mathrm{l})\end{array}$ & $\begin{array}{l}\mathrm{NH}_{3}-\mathrm{N} \\
(\mathrm{mg} / \mathrm{l})\end{array}$ & $\begin{array}{l}\mathrm{BOD}_{5} \\
(\mathrm{mg} / \mathrm{l})\end{array}$ & $\begin{array}{l}\text { COD } \\
(\mathrm{mg} / \mathrm{l})\end{array}$ & $\begin{array}{l}\mathrm{NH}_{3}-\mathrm{N} \\
(\mathrm{mg} / \mathrm{l})\end{array}$ \\
\hline \multirow{4}{*}{ Stage 1} & 0 & 1002 & 9975 & 1158 & 1002 & 9975 & 1158 \\
\hline & 7 & 646 & 5550 & 981 & 646 & 5550 & 981 \\
\hline & 14 & 257 & 3760 & 983 & 257 & 3760 & 983 \\
\hline & 21 & 192 & 2444 & 999 & 192 & 2444 & 999 \\
\hline \multirow{3}{*}{ Stage 2} & 21 & 1242 & 8820 & 782 & 1242 & 8820 & 999 \\
\hline & 28 & 1106 & 3044 & 261 & 936 & 3044 & 782 \\
\hline & 35 & 834 & 2750 & 1030 & 654 & 2750 & 261 \\
\hline \multirow{6}{*}{ Stage 3} & 35 & 2710 & 17497 & 1012 & 2710 & 17497 & 1022 \\
\hline & 42 & 1490 & 5532 & 988 & 1085 & 5532 & 990 \\
\hline & 49 & 1674 & 6617 & 943 & 1278 & 6617 & 570 \\
\hline & 56 & 956 & 6365 & 346 & 1000 & 6365 & 450 \\
\hline & 61 & 111 & 2177 & 320 & 210 & 2177 & 375 \\
\hline & 62 & - & 1840 & 742 & - & 1840 & 742 \\
\hline \multirow{2}{*}{ Stage 4} & 69 & 3994 & 12400 & 838 & 4077 & 12400 & 1013 \\
\hline & 79 & 2691 & 10440 & 916 & 1269 & 10440 & - \\
\hline \multirow{4}{*}{ Stage 5} & 80 & 2034 & 12836 & 1002 & 2034 & 12836 & 1002 \\
\hline & 82 & 1547 & 11219 & 960 & 1643 & 11219 & 981 \\
\hline & 84 & 1956 & 12543 & 871 & 902 & 12543 & 916 \\
\hline & 88 & 1244 & 13826 & 555 & 1652 & 13826 & 496 \\
\hline \multirow{3}{*}{ Stage 6} & 88 & 1841 & 10790 & 1193 & 1665 & 10790 & 1193 \\
\hline & 90 & 2340 & 12140 & 1060 & 1244 & 12140 & 529 \\
\hline & 95 & 781 & 10132 & 775 & 905 & 10132 & 498 \\
\hline
\end{tabular}




\section{Appendix-4 \\ Supplementary Photographs}

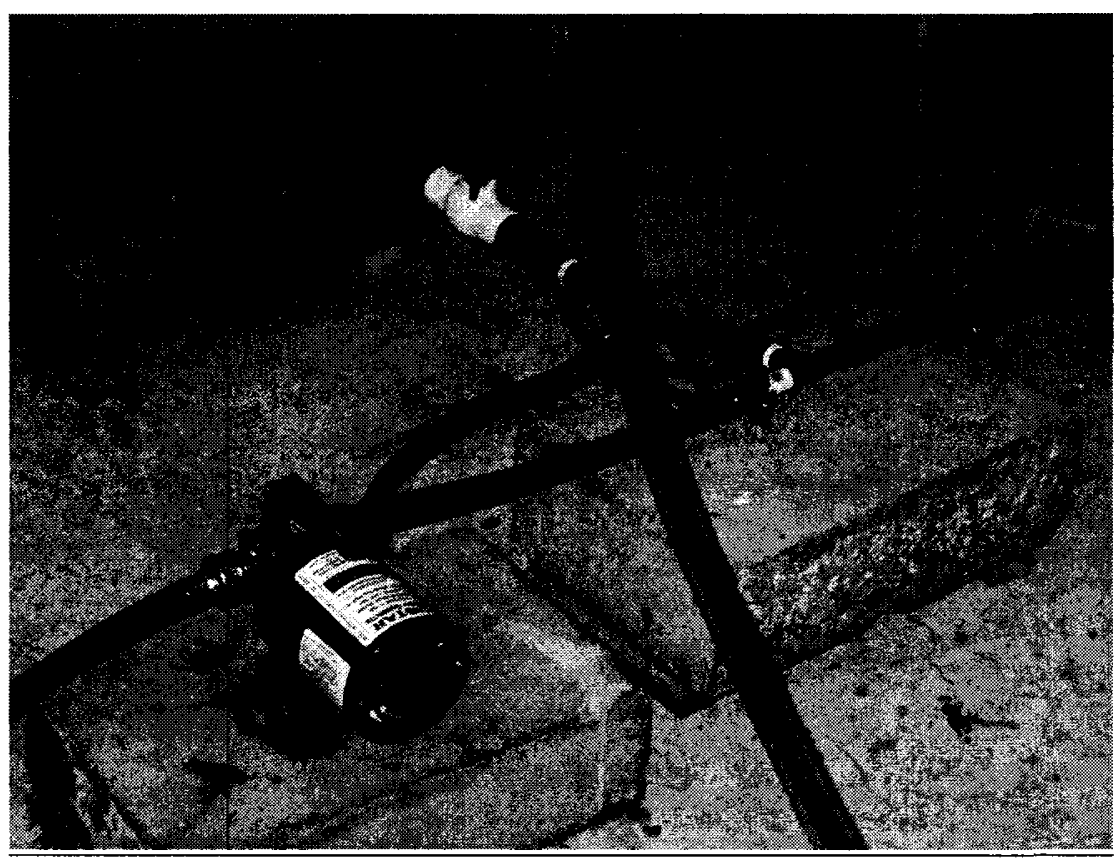

\section{Raw leachate pump with by-pass arrangement}

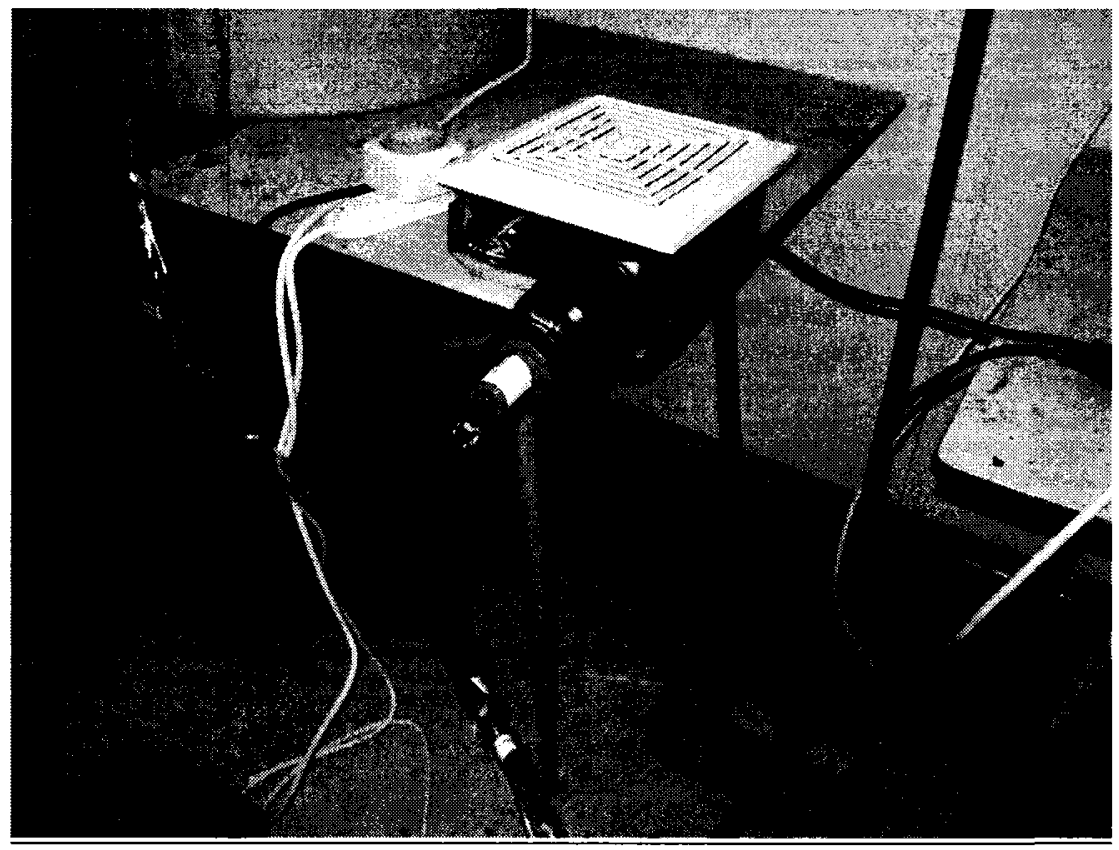

Small ventilation fan with timer arrangement 


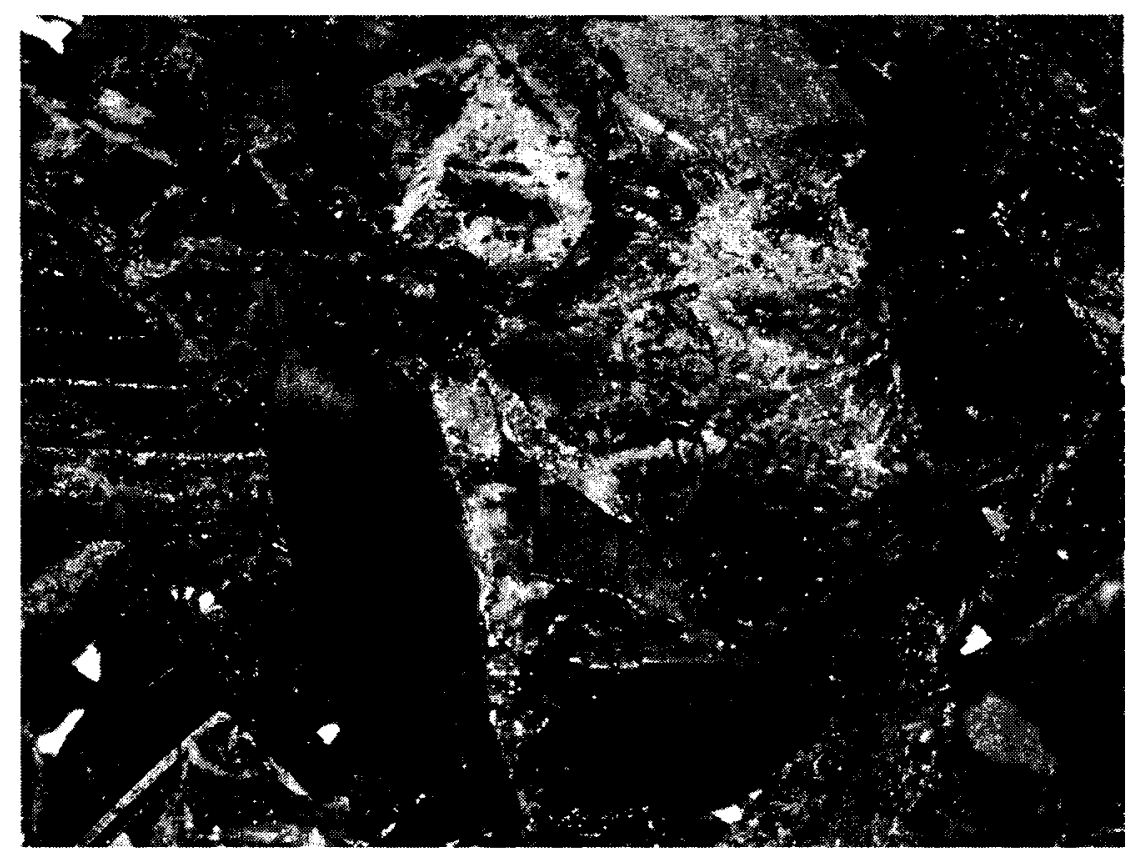

\section{Biomass growth on tire chips}

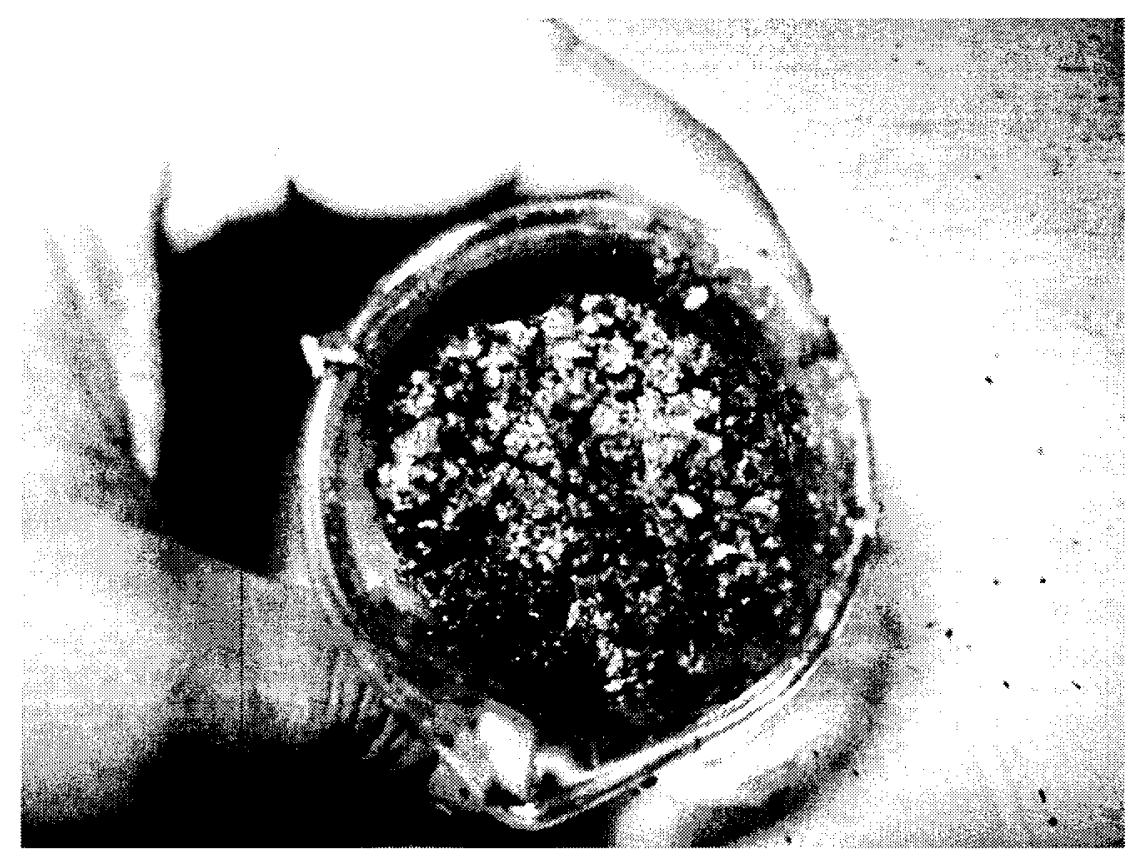

Biomass growth on tire crumbs 